\begin{tabular}{|l|l|}
\hline $\begin{array}{l}\text { 2. To: (Receiving Organization) } \\
\text { Distribution }\end{array}$ & $\begin{array}{l}\text { 3. From: Coriginating Organization) } \\
\text { SST Retrieval }\end{array}$ \\
\hline 5. Proj./Prog./Dept./Div.: & $\begin{array}{l}\text { 6. Design Authority/ Design Agent/Cog } \\
\text { Engr.: }\end{array}$ \\
TWRS SST Retrieval Program & W. J. Stokes \\
\hline 8. Originator Remarks: &
\end{tabular}

8. Originator Remarks:

For approval and release

11. Receiver Renarks: 11A. Design Baseline Document? [] Yes [X] No

Transmittal Letter LMHC-9761599A R4 $\underset{8-7-98}{\infty 0}$
4. Related EDT No.:

NA

7. Purchase Order No.:

NA

9. Equip./Component No.:

NA

10. System/Bldg./Facility: NA

12. Major Assm. Dwg. No.: NA

13. Permit/Permit Application No.: NA

14. Required Response Date:

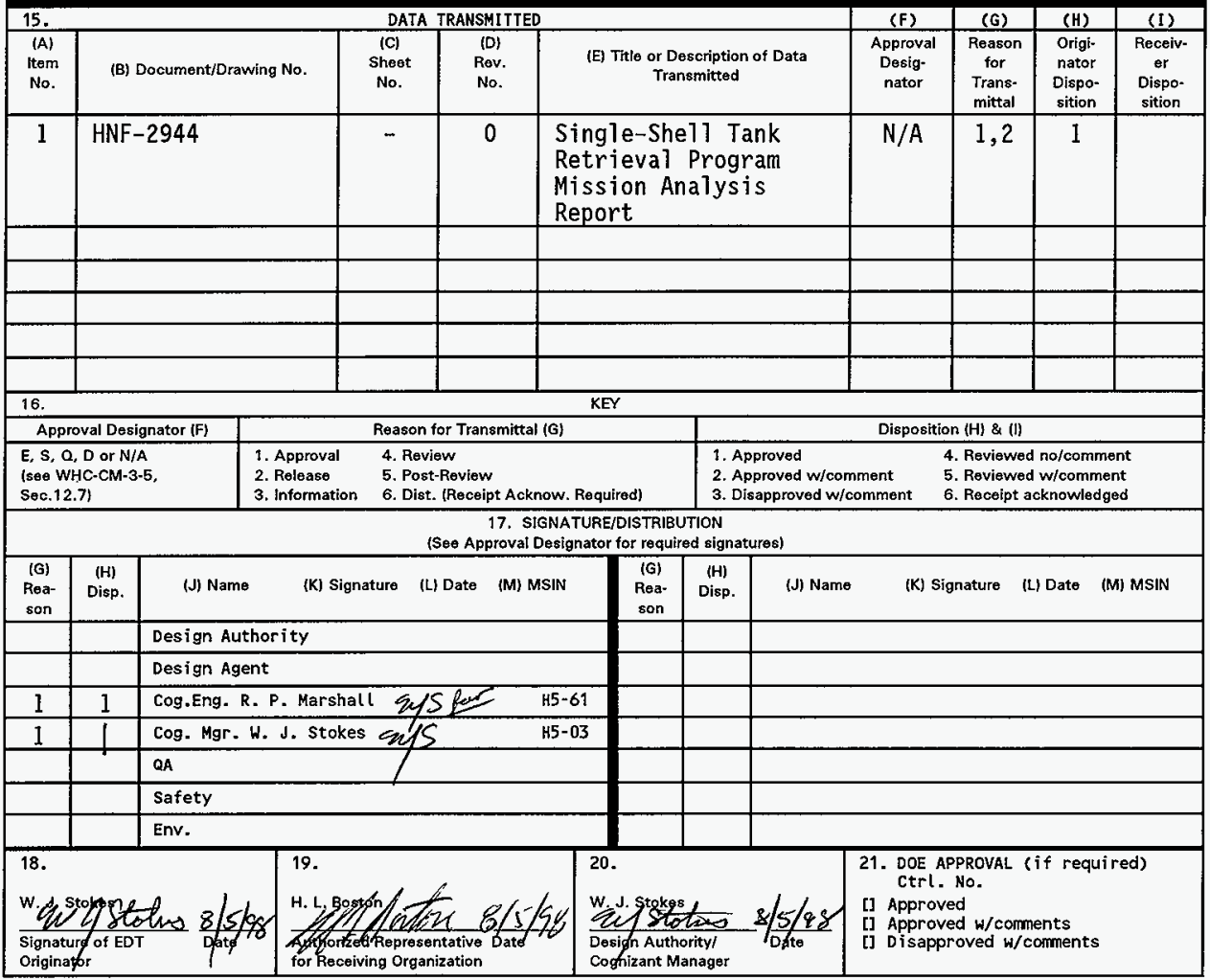




\title{
Single-Shell Tank Retrieval Program Mission Analysis Report
}

Lockheed Martin Hanford Corporation, Richland, WA 99352

U.S. Department of Energy Contract DE-AC06-96RLI3200

\author{
EDT/ECN: 624557 \\ Org Code: 73000 \\ UC: $721, U C-2000$ \\ B\&R Code: EW3130010 \\ Charge Code: D234B \\ Total Pages: $153 \quad \mathrm{ew}_{8-7-98}$
}

Key Words: mission analysis, TWRS, SST

Abstract: This Mission Analysis Report was prepared to provide the foundation for the Single-Shell Tank (SST) Retrieval Program, a new program responsible for waste removal for the SSTs. The SST Retrieval Program is integrated with other Tank Waste Remediation System activities that provide the management, technical, and operations elements associated with planning and execution of SST and SST Farm retrieval and closure. This Mission Analysis Report provides the basis and strategy for developing a program $\mathrm{plan}$ for SST retrieval. This Mission Analysis Report responds to a U.S. Department of Energy request for an alternative single-shell tank retrieval approach (Taylor 1997).

TRADEMARK DISCLAIMER. Reference herein to any specific comercial product, process, or service by trade name, trademark, manufacturer, or otherwise, does not necessarily constitute or imply its endorsement, recomendation, or favoring by the United States Govermment or any agency thereof or its contractors or subcontractors.

Printed in the United States of America. To obtain copies of this docunent, contact: Document Control Services, P.0. Box 950, Mailstop H6-08, Richland WA 99352, Phone (509) 372-2420;

Fax (509) 376-4989.

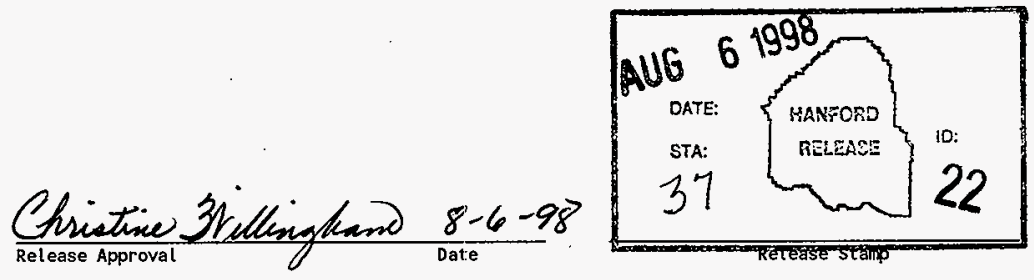

Approved for Public Release 
HNF-2944

Revision 0

\section{SINGLE-SHELL TANK RETRIEVAL PROGRAM MISSION ANALYSIS REPORT}

July 1998

Prepared by:

Lockheed Martin Hanford Corporation

Richland, Washington

Prepared for:

U.S. Department of Energy

Richland, Washington 
HNF-2944

Revision 0

This page intentionally left blank. 
HNF-2944

Revision 0

\section{EXECUTIVE SUMMARY}

One-hundred forty-nine single-shell underground storage tanks located in the 200 Areas of the U.S. Department of Energy Hanford Site contain approximately $133,000 \mathrm{~m}^{3}$ (35 Mgal) of hazardous high-level radioactive waste. The tanks were constructed between 1944 and 1964 and have exceeded their design life. Sixty-seven (67) tanks are known or suspected to have leaked waste to the subsurface. Some tank leaks have reached the groundwater. As part of the Tank Waste Remediation System Project, the waste will be retrieved from the single-shell tanks, immobilized (vitrified), and dispositioned. Pumpable liquids have been removed from all but 30 single-shell tanks, and efforts to remove liquids from those tanks are underway. Regulatory milestones require liquid and solid waste to be removed from the single-shell tanks by 2018. The tank farms will be closed consistent with site clean up objectives as governed by the Hanford Federal Facility Agreement and Consent Order (Tri-Party Agreement) (Ecology et al. 1996) between the U.S. Department of Energy, the State of Washington, and the U.S. Environmental Protection Agency.

This mission analysis report builds upon the Tank Waste Remediation System Mission Analysis Report. This Single-Shell Tank Retrieval Program Mission Analysis Report (1) describes and analyzes the Single-Shell Tank Retrieval Program requirements, interfaces, and objectives, (2) assesses the current single-shell tank retrieval planning bases against those requirements and objectives, and (3) presents an alternative single-shell tank retrieval strategy that addresses some of the issues and constraints for developing an optimal Single-Shell Tank Retrieval Program Plan and that provides opportunities for enhancing mission performance and success. This analysis provides the foundation for systematic development of the SingleShell Tank Retrieval Program. The formulation of the single-shell tank retrieval strategy, presented in this report, is the initial step in development of an alternative single-shell tank retrieval technical baseline.

The development of a technical baseline and plans for single-shell tank retrieval are constrained by uncertainties in end points and requirements (e.g., the amount of waste that 
HNF-2944

Revision 0

must be retrieved from each tank), and by limited technical information (e.g, the potential leakage that may occur from tanks during retrieval using various retrieval technologies, and the implications of such leaks on health and the environment). The development of a technical baseline and program plan are also constrained by physical and logistical challenges (e.g., double-shell tank space available to hold retrieved single-shell tank waste, and the availability and processing rates of waste immobilization facilities). The information and assessments in this document reflect the current planning assumptions, conditions, and requirements for tank farms, Tank Waste Remediation System Privatization, and regulatory commitments.

The alternative Single-Shell Tank Retrieval Program strategy addresses some of the key programmatic and technical uncertainties and highlights others for resolution. This strategy calls for waste retrieval from sound single-shell tanks to begin in parallel with efforts to provide information needed to make programmatic and regulatory decisions. Such decision making will support development of an optimal program for completing the single-shell tank retrieval mission. This approach allows the Tank Waste Remediation System Project to (1) proceed with waste retrieval to meet Tri-Party Agreement milestones, (2) remove waste to reduce the risk of additional leakage, and (3) remove wastes from single-shell tanks so that, in the event of a catastrophic failure, significant impacts to the health, the environment, and the regional economy do not occur.

The alternative strategy provides the foundation for the systematic development of a technical baseline and plans for the single-shell tank retrieval component of the Tank Waste Remediation System mission. This Mission Analysis Report is maintained under configuration management and will be subject to a change control process to reflect changes in requirements, assumptions, and conditions. 
HNF-2944

Revision 0

CONTENTS

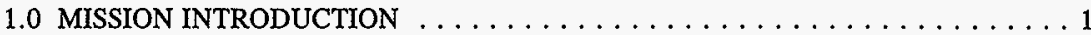

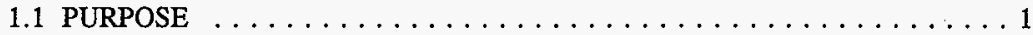

1.2 SINGLE-SHELL TANK RETRIEVAL PROGRAM MISSION $\ldots \ldots \ldots \ldots 2$

1.3 RELATIONSHIP TO TANK WASTE REMEDIATION SYSTEM MISSION . . . 3

1.4 SINGLE-SHELL TANK RETRIEVAL PROGRAM SCOPE . . . . . . . . 9

1.5 STAKEHOLDERS AND REGULATORS $\ldots \ldots \ldots \ldots \ldots \ldots$

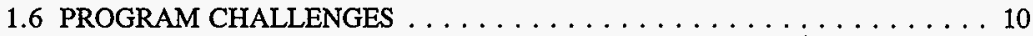

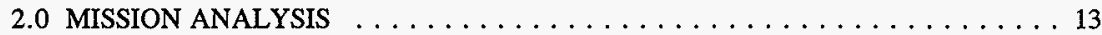

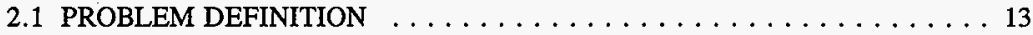

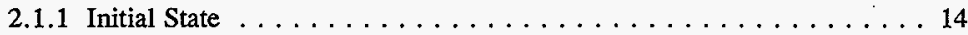

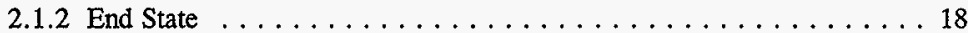

2.1.3 Mission Goals and Objectives $\ldots \ldots \ldots \ldots \ldots \ldots \ldots \ldots$

2.2 SINGLE-SHELL TANK RETRIEVAL PROGRAM MISSION STATEMENT . 20

2.3 SINGLE-SHELL TANK RETRIEVAL PROGRAM FUNCTIONS AND

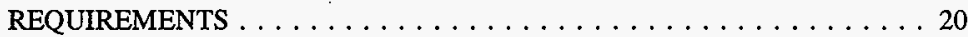

2.3.1 Single-Shell Tank Retrieval Program Functions $\ldots \ldots \ldots \ldots \ldots . \ldots 20$

2.3.2 Single-Shell Tank Retrieval Program Requirements . . . . . . . . 21

2.4 SINGLE-SHELL TANK RETRIEVAL PROGRAM CONSTRAINTS

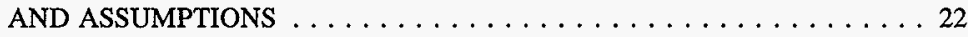

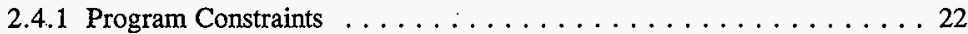

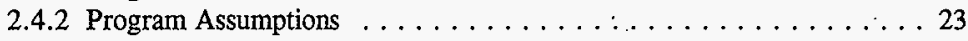

2.5 SYSTEM BOUNDARIES AND EXTERNAL INTERFACES $\ldots \ldots \ldots \ldots 24$

2.6 TEST AND EVALUATION METHODOLOGY . . . . . . . . . . 29

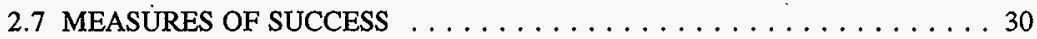

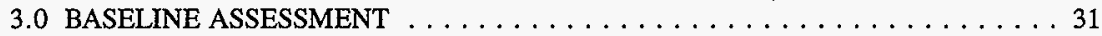

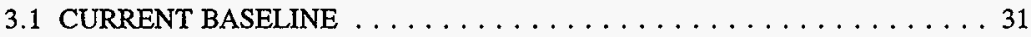

3.2 REQUIREMENTS AND ASSUMPTIONS $\ldots \ldots \ldots \ldots \ldots \ldots \ldots \ldots$

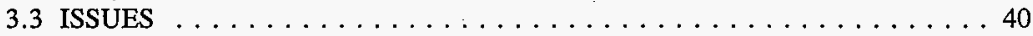

4.0 ALTERNATIVE SINGLE-SHELL TANK RETRIEVAL STRATEGY $\ldots \ldots \ldots 43$

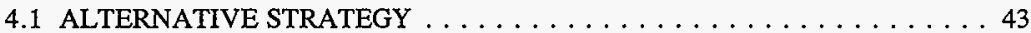

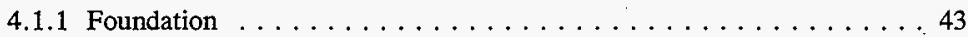

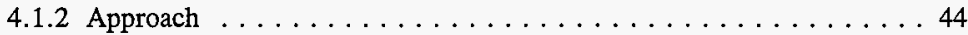

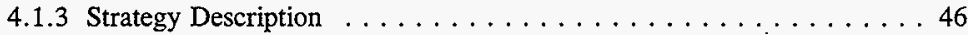

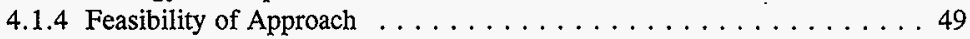

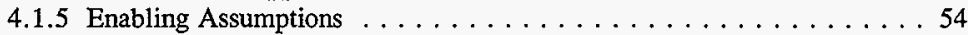

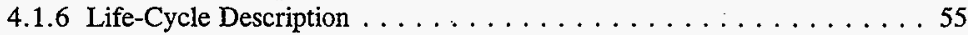

4.1.7 Program Integration $\ldots \ldots \ldots \ldots \ldots \ldots \ldots \ldots \ldots \ldots \ldots \ldots$

4.2 COMPARISON BETWEEN ALTERNATIVE STRATEGY AND

CURRENT BASELINE $\ldots \ldots \ldots \ldots \ldots \ldots \ldots \ldots \ldots \ldots \ldots \ldots \ldots \ldots$ 
HNF-2944

Revision 0

4.2.1 Retrieval Endpoints and Requirements Determinations . . . . . . . 60

4.2.2 Impact of Leaks on Public Health and the Environment . . . . . . . 6 61

4.2 .3 Feasibility of Retrieval Logistics . . . . . . . . . . . . 62

4.2.4 Double-Shell Tank System Space Availability . . . . . . . . . . . 64

4.3 STAKEHOLDER VALUES $\ldots \ldots \ldots \ldots \ldots \ldots \ldots \ldots \ldots \ldots \ldots \ldots$

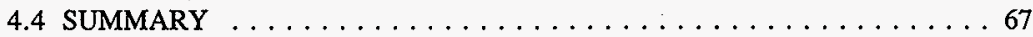

5.0 REFERENCES . . . . . . . . . . . . . . . . . . . . . . 69

APPENDICES

A - TANK STATUS FOR WASTE FORM AND INTEGRITY $\ldots \ldots \ldots \ldots$ A-1

B - SOURCES OF SINGLE-SHELL TANK WASTES $\ldots \ldots \ldots \ldots \ldots$ B-1

C - SINGLE-SHELL TANK RETRIEVAL PROGRAM APPLICABLE TRI-PARTY AGREEMENT MILESTONES $\ldots \ldots \ldots \ldots \ldots \ldots \ldots$. . . .

D - TANK WASTE REMEDIATION SYSTEM EXTERNALLY IMPOSED REQUIREMENTS . . . . . . . . . . . . . . . . D-1

E - SINGLE-SHELL TANK RETRIEVAL INFORMATION AND TOOLS . . . E E-1

\section{TABLES}

2-1. Selected Tri-Party Agreement Milestones for Single-Shell Tank Retrieval. . . . . . 21

4-1. Comparison of Tank Waste Remediation System Planning Baseline and Example Mission Improvements Case. 
HNF-2944

Revision 0

FIGURES

1-1. Relationship of Tank Waste Remediation System Program Elements. . . . . . . . 5

1-2. Tank Waste Remediation System Assigned Functional Requirements. . . . . . . 7

1-3. Tank Waste Remediation System Timeline. . . . . . . . . . . . . 8

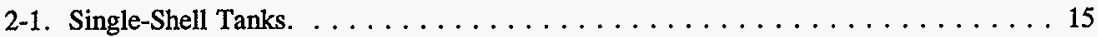

2-2. Historical Tank Leakage. $\ldots \ldots \ldots \ldots \ldots \ldots \ldots \ldots \ldots \ldots \ldots \ldots \ldots$

2-3. Hierarchy of Hanford Programs and Organizations that Support

Tank Waste Remediation System Single-Shell Tank Retrieval. . . . . . . . . . 26

3-1. Cumulative Number of Single-Shell Tanks Initiated for Retrieval $\ldots \ldots \ldots \ldots 33$

3-2. Phase $1 B$ and Phase 2 Low-Activity Waste Processing Rates. . . . . . . . 35

3-3. Waste Volumes Remaining in Single-Shell Tanks Over Time. . . . . . . . . 36

3-4. Tank Farm System Retrieval and Transfer Infrastructure. . . . . . . . . . 37

4-1. Single-Shell Tank Retrieval Program Strategy $\ldots \ldots \ldots \ldots \ldots \ldots \ldots$

4-2. Single-Shell Tank Retrieval Program Approach. . . . . . . . . . . . 48

4-3. Single-Shell Tank Retrieval Initiation. . . . . . . . . . . . . 50

44. Single-Shell Tank Technetium Inventory. $\ldots \ldots \ldots \ldots \ldots \ldots \ldots \ldots \ldots$

4-5. Level 0.5 Logic for Single-Shell Program. . . . . . . . . . . . . . . 56

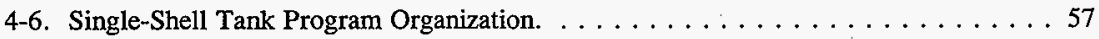

4-7. Single-Shell Tank Program Integration. . . . . . . . . . . . . . . . 59

4-8. Example Mission Improvements--Low-Activity Waste Processing. . . . . . . . . 64 
HNF-2944

Revision 0

This page intentionally left blank. 
HNF-2944

Revision 0

\section{LIST OF TERMS}

ACTR

ALARA

BBI

CCS

CPT

D\&D

DST

DOE

DQO

Ecology

EIS

EPA

ERT

F\&R

FDH

FY

HLW

HSTD

HTI

HTWOS
Acquire Commercial Technology for Retrieval

As low as reasonably achievable

Best-Basis Inventory

Controlled, Clean, and Stable

Cone penetrometer

Decontamination and Decommissioning

Double-shell tank

U.S. Department of Energy

Data Quality Objective

Washington State Department of Ecology

Environmental Impact Statement

U.S. Environmental Protection Agency

Electrical resistance tomography

Functions and Requirements

Fluor Daniel Hanford

Fiscal Year

High-level waste

Hanford Site Technical Database

Hanford Tanks Initiative

Hanford Tank Waste Operation Simulator 
HNF-2944

Revision 0

\section{LIST OF TERMS (CONTINUED)}

HTWTF

HVAC

ICP-MS

ILAW

IMUST

INEEL

ISSTRS

LAW

LDMM

LDUA

LLMR

LLW

MA

MAR

MEI

METC

MUST

MYWP

NEPA

NRC

OCRWM
Hanford Tank Waste Task Force

Heating, ventilating, and air conditioning

Inductively coupled plasma-mass spectrometry

Immobilize Low-Activity Waste

Inactive Miscellaneous Underground Storage Tanks

Idaho National Engineering Environment Laboratory

Initial Single-Shell Tank Retrieval System

Low-activity waste

Leakage detection, monitoring, and mitigation

Light-duty utility arm

Long lived mobile radionuclides

Low-level waste

Mission Analysis

Mission Analysis Report

Maximally exposed individual

Morgantown Energy Technology Center

Miscellaneous Underground Storage Tanks

Multi-Year Work Plan

National Environmental Policy Act of 1969

U. S. Nuclear Regulatory Commission

Office of Civilian Radioactive Waste Management 
HNF-2944

Revision 0

\section{LIST OF TERMS (CONTINUED)}

ORNL

OWVP

PHMC

PUREX

RA

RBA

RCRA

REM

RL

ROD

SCC

Sound tank

SRS

SSSTRS

SST

$\mathrm{T} \& \mathrm{E}$

TCR

TFA

TMS

TSD
Oak Ridge National Laboratory

Operational Waste Volume Projection

Project Hanford Management Contract

Plutonium-Uranium Extraction

Radiation Area

Radiation Buffer Area

Resource Conservation and Recovery Act of 1976

Retrieval Evaluation Model

U.S. Department of Energy, Richland Operation Office

Record of Decision

Stress corrosion cracking

Tank for which surveillance data indicate no loss of liquid attributed to a breach of integrity (Hanlon 1998)

Savannah River Site

Subsequent Single-Shell Tank Retrieval System

Single-shell tank

Test and evaluation

Tank Characterization Report

Tanks Focus Area

Topographical mapping system.

Treatment, Storage and/or Disposal 
HNF-2944

Revision 0

LIST OF TERMS (CONTINUED)

TWRS

TWRSO\&UP

URMA

WIDS

WIT

WRF
Tank Waste Remediation System

Tank Waste Remediation System Operation and Utilization Plan

Underground Radiation Management Area

Waste Information Data System

Waste Integration Team

Waste Retrieval Facility 
HNF-2944

Revision 0

\section{SINGLE-SHELL TANK RETRIEVAL PROGRAM MISSION ANALYSIS REPORT}

\subsection{MISSION INTRODUCTION}

\subsection{PURPOSE}

This Mission Analysis Report (MAR) was prepared to provide the foundation for the Single-Shell Tank (SST) Retrieval Program, a new program responsible for waste removal for the SSTs. The SST Retrieval Program is integrated with other Tank Waste Remediation System (TWRS) activities that provide the management, technical, and operations elements associated with planning and execution of SST and SST Farm retrieval and closure. This MAR provides the basis and strategy for developing a program plan for SST retrieval. The SST Retrieval Program Plan will integrate with other program plans (e.g., vadose zone, characterization, and waste retrieval technology development plans) necessary to assure safe, compliant, and cost-effective waste retrieval.

The strategy for the SST Retrieval Program was developed in response to the U.S. Department of Energy (DOE) request for an alternative approach to SST waste retrieval (Taylor 1997). This strategy provides a planning basis that builds upon higher-level planning bases (e.g., the Tank Waste Remediation System Mission Analysis Report [Acree 1998] and the Management Assessment of Tank Waste Remediation System Contractor Readiness to Proceed With Phase 1B Privatization [Payne 1998]) while recognizing that existing conditions and uncertainties constrain the ability to retrieve SST waste at the present time. The new strategy defines a two-track approach that satisfies the need to move forward with waste retrieval while uncertainties and constraints are being resolved. The strategy included within this document identifies requirements, assumptions, analyses, and other information required for developing the SST Retrieval Program Plan.

This SST Retrieval Program MAR does the following:

- Describes and analyzes the SST Retrieval program requirements and objectives

- Assesses the current programmatic baseline against those requirements and objectives

- Presents alternatives for enhancing program performance and opportunity for success

- Provides assessment of the information needs. 
HNF-2944

Revision 0

This MAR is organized as follows:

- Section 1.0 introduces the scope of the SST Retrieval Program in relation to the overall TWRS Project mission. Concerns and values of the Stakeholders and regulators are identified, as are the most significant constraints and uncertainties facing the program.

- Section 2.0 defines the initial state, end state, mission goals and objectives. The mission is summarized. Mission functions, requirements, constraints, assumptions, and system boundaries and interfaces that frame the mission are described. Measures of success are identified.

- Section 3.0 presents the current baseline and the guidelines and assumptions used to develop the baseline. The baseline is evaluated in the context of existing requirements, constraints, and objectives. Issues that are barriers to success are identified.

- Section 4.0 presents the alternative SST retrieval strategy. The foundation and approach of the strategy are evaluated. Enabling assumptions and remaining issues to be resolved are included. Integration of program components to carry out the strategy is discussed.

- The appendices provide supplemental technical and programmatic information related to tank conditions, waste sources, Hanford Federal Facility Agreement and Consent Order (Tri-Party Agreement) (Ecology et al. 1996) milestones, requirements, and applicable technologies.

This MAR is the initial step in the development of an alternative technical baseline for the retrieval of waste from SSTs. The MAR and alternative logic were developed in response to a DOE request (Taylor 1997). The information and assessments in this document reflect the current planning assumptions, conditions, and requirements for tank farms, TWRS Privatization, and regulatory commitments. ${ }^{1}$

\subsection{SINGLE-SHELL TANK RETRIEVAL PROGRAM MISSION}

The mission of the SST Retrieval Program is to retrieve wastes from the SSTs in the 200 Areas of the Hanford Site in a safe, economical manner, transfer the waste to the

${ }^{1}$ Current planning assumptions, conditions, and requirements were derived from the TWRS Environmental Impact Statement (EIS) (DOE 1996), Hanford Site Environmental Management Specification (DOE 1997a), TWRS Waste Disposal Division Planning Guidance (DOE 1997b), and the Supplemental Analysis for the Tank Waste Remediation System (DOE 1998). 
designated receiver facilities, i.e., double-shell tanks (DSTs), and transition the tanks for closure, without posing an undo public health or environmental risk. The SST Retrieval Program is required to meet the Tri-Party Agreement commitments while providing feed for the TWRS tank waste immobilization facilities.

\subsection{RELATIONSHIP TO TANK WASTE REMEDIATION SYSTEM MISSION}

The TWRS mission is defined in the Tank Waste Remediation System Mission Analysis Report (Acree 1998) and it includes: (1) resolve safety issues; (2) operate, maintain and upgrade the tank farms and supporting infrastructure; (3) construct, operate, and maintain facilities that are necessary for waste storage, retrieval, waste separation, waste preparation, immobilization, and disposal; (4) characterize, retrieve, pretreat, and immobilize waste for disposal, (5) provide for the disposition of the cesium and strontium capsule contents;

(6) provide disposal of immobilized low-activity waste (ILAW); (7) provide interim storage of immobilized high-level waste (HLW) until it is shipped to the national geological repository; and (8) provide for the closure and decontamination and decommissioning (D\&D) of TWRS facilities and post-closure monitoring (Acree 1998).

The TWRS materials flow for Phase 1 waste immobilization is captured in Figure 1-1. The SST Retrieval Program element provides the feed for waste immobilization and removes the waste required for achieving tank and tank farm closure in conformance with regulatory requirements.

The TWRS mission has been defined in terms of TWRS Program Functions and Requirements (F\&R) (Acree 1998). The F\&R related to SST Retrieval is: the SST System will remove the waste from the SSTs and transfer it to the DST System for waste processing. This activity is complete when sufficient wastes have been removed from the SST System and transferred to the DST System to allow tank closure.

The Hanford Site Technical Database (HSTD) is the integrated site technical baseline. It contains site requirements, functions, and major facilities that are allocated to projects, such as TWRS, and subtier programs, such as SST Retrieval. The SST Retrieval Program functions, requirements, goals, and objectives are traceable to the TWRS MAR (Acree 1998) and the HSTD as depicted in Figure 1-2.

Figure 1-3 shows a time line of activities related to SST Retrieval. SST Retrieval begins during Phase 1 immobilization and continues into Phase 2 immobilization, with completion in 2018. This time line conforms to the current milestones established by joint agreement (Tri-Party Agreement) among Washington State Department of Ecology (Ecology), U.S. Environmental Protection Agency (EPA), and DOE, This time line shows how various elements of the TWRS mission are sequenced in time. 
HNF-2944

Revision 0

This page intentionally left blank. 


\section{Revision 0}

TWRS WASTE DELIVERY SCHEMATIC -- Phase 1"

Figure 1-1. Relationship of Tank Waste Remediation System Program Elements.

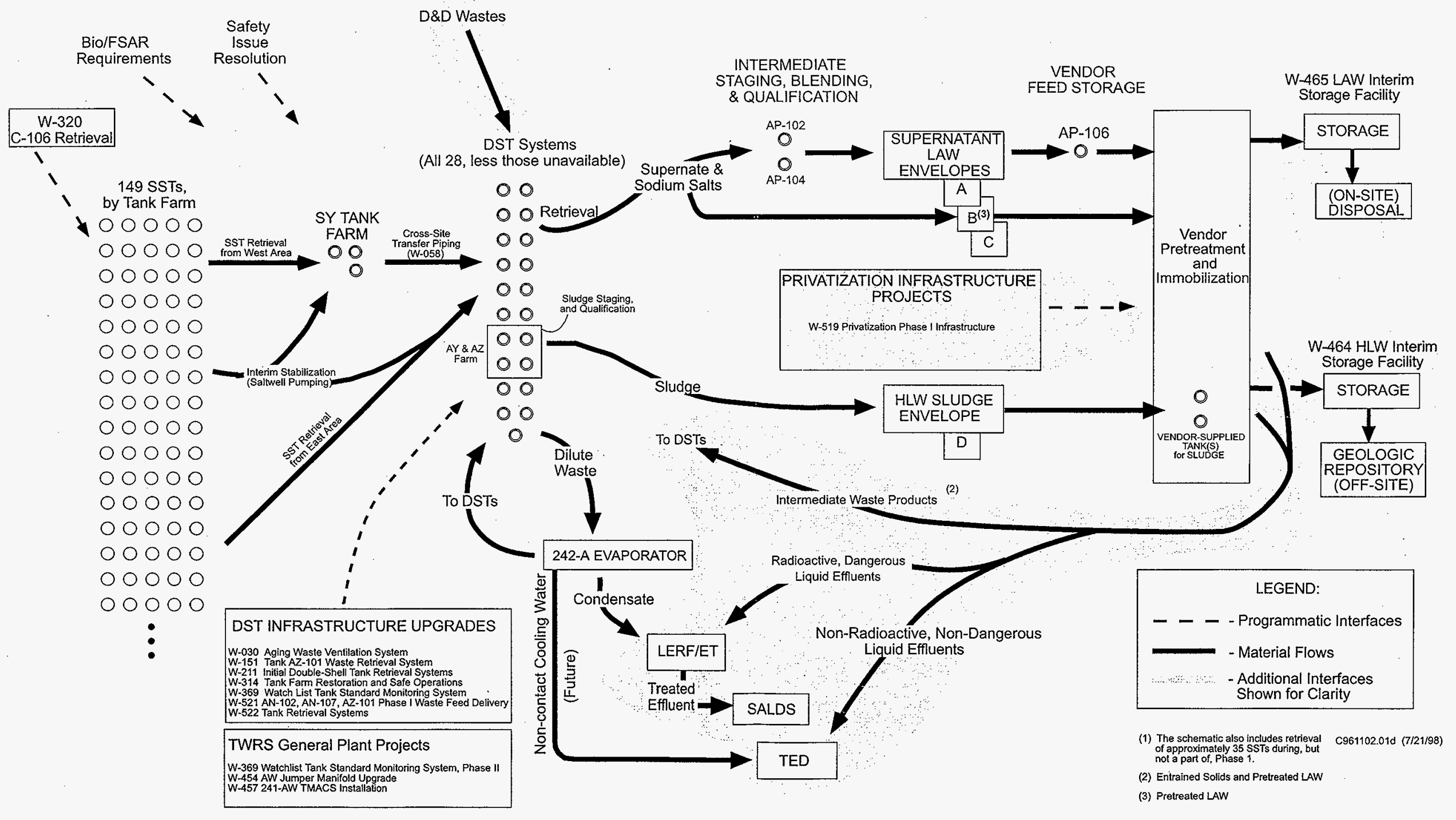




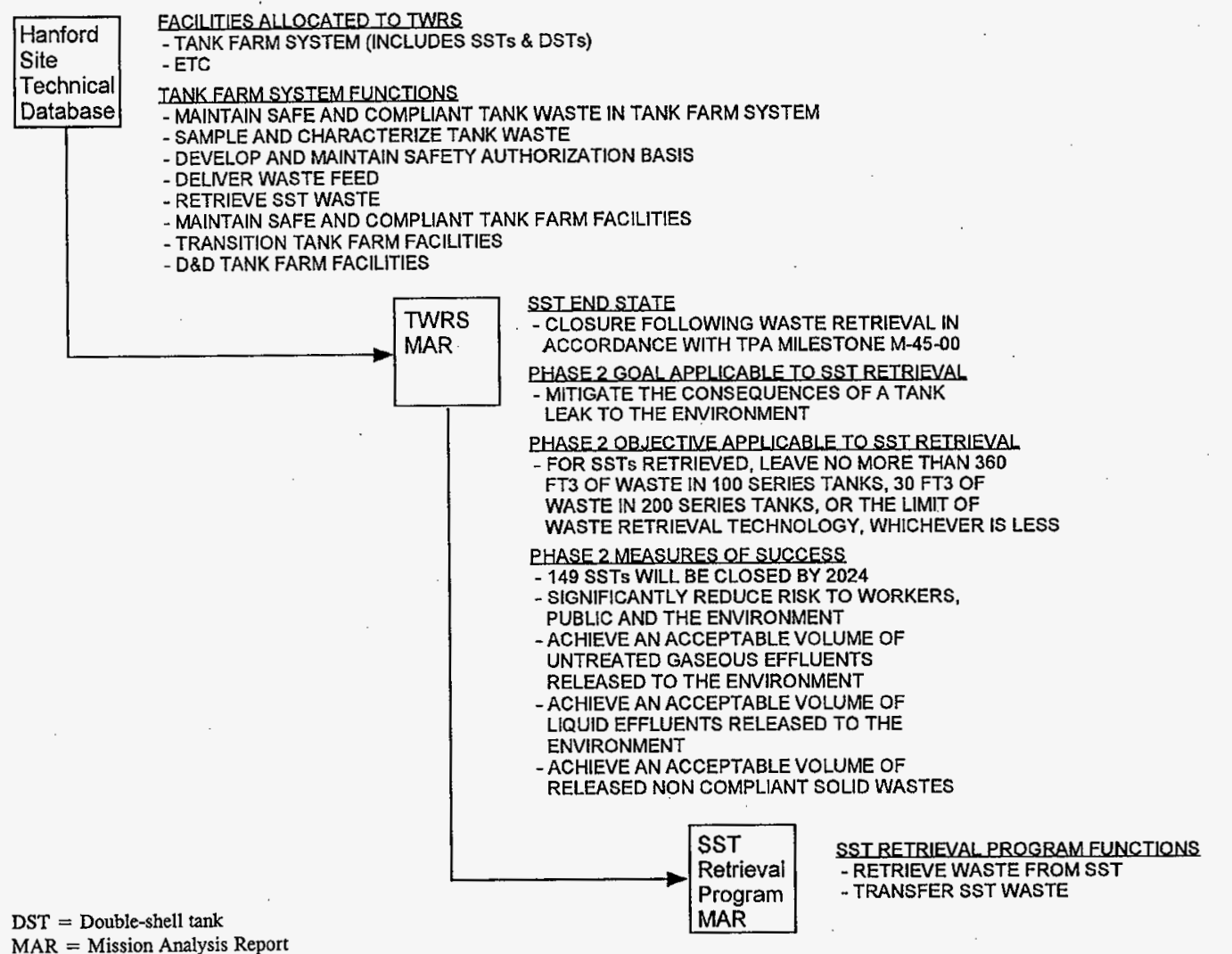

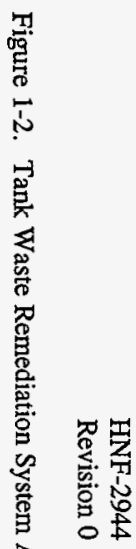

MAR $=$ Mission Analysis Report 


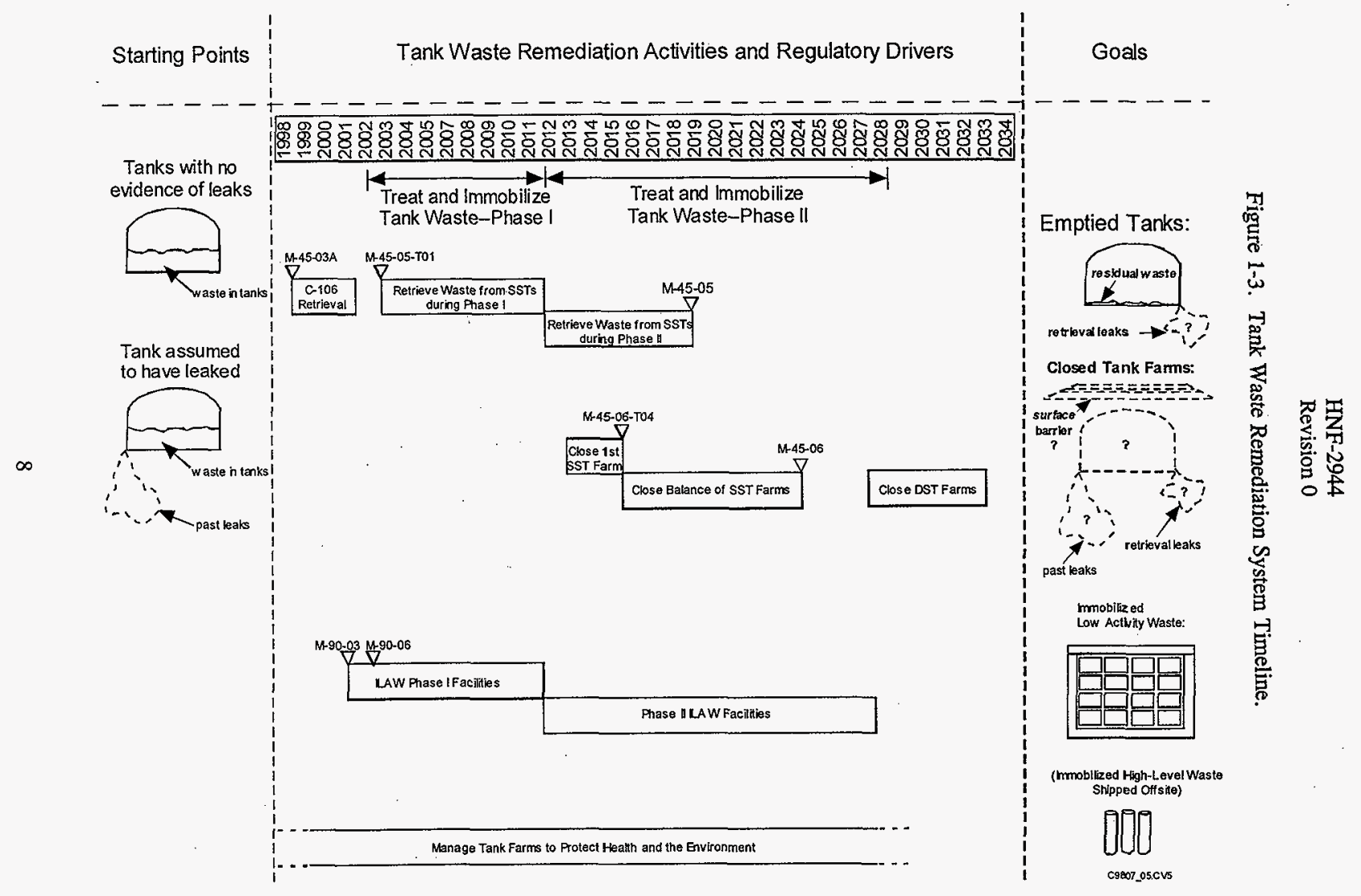




\subsection{SINGLE-SHELL TANK RETRIEVAL PROGRAM SCOPE}

The scope of the SST Retrieval Program includes all programmatic activities necessary to retrieve waste from the 149 underground single-shell waste storage tanks, transfer the retrieved wastes to designated receiver facilities, and transition the retrieved tanks and ancillary facilities to the TWRS SST Closure Program. The current scope incorporates activities to select and design, procure, deploy and disposition the necessary waste retrieval systems, and transfer systems for 33 of the SSTs. Three of the SSTs are within the scope of the Waste Feed Delivery Program. For the remaining 113 SSTs, current planning requires the SST Retrieval Program to support development of a specification and to provide procurement support for the privatization of the retrieval function.

High-level radioactive waste has been stored at the Hanford Site since 1944 as a by-product of processing spent nuclear fuel for the recovery of plutonium, uranium, and neptunium. The first SST was completed and put into operation in 1944. Between 1944 and 1964, 149 SSTs were built for the storage of radioactive waste. These SSTs are in 12 tank farms, consisting of four to 18 tanks each, located in the 200 East and 200 West Areas of the Hanford Site. The SSTS were constructed of a carbon steel single shell housed in a steel reinforced concrete wall and dome. No waste has been added to the SSTs since November 1980. The SSTs contain approximately $133,000 \mathrm{~m}^{3}$ (35 Mgal) of non-pumpable waste in the form of saltcake, approximately $87,000 \mathrm{~m}^{3}(23 \mathrm{Mgal})$, and sludge, approximately $45,000 \mathrm{~m}^{3}$ (12 Mgal) (Hanlon 1998).

In 1978, interim stabilization was initiated to remove pumpable liquids from suspect SSTs to reduce leak potential. Pumpable liquids are being removed from SSTs and transferred to the DSTs. SSTs contain approximately $22,000 \mathrm{~m}^{3}(5.8 \mathrm{Mgal})$ of pumpable liquids (Hanlon 1998). Removal of pumpable liquids as part of the Interim Stabilization Project (Ross et al. 1998 ) is not part of the SST Retrieval Program scope.

\subsection{STAKEHOLDERS AND REGULATORS}

The concerns and values of the stakeholders are important for evaluating the mission and developing a solution. The public stakeholders include the citizen action groups, the general public, local governments, affected federal agencies, and the Tribal Nations. The SST Retrieval Program's principal regulator is Ecology who, along with EPA and DOE, are the signatories to the Tri-Party Agreement.

The SST Retrieval Program has as a driving goal and objective, risk reduction to workers, the public, and the environment. This goal and objective can be related to specific stakeholder values that impact the way in which the SST Retrieval Program is carried out. These values are found in Final Report: Hanford Tank Waste Task Force (HTWTF 1993) and Public Values Related to Decisions in the Tank Waste Remediation System Program (Dirks and VonWinterfeldt 1994) and are listed below: 
HNF-2944

Revision 0

- Protect the public, and worker health and safety.

- Protect the Columbia River.

- Clean up to the level necessary to enable future use options to occur.

- Capture economic development opportunities locally.

- Protect the rights of the Tribal Nations.

- Ensure compliance.

- Reduce Cost.

- Use a systems approach.

- Do not rely on unproven technologies, and use technology innovations as they become available.

- Make progress with the cleanup activities.

- Allocate funds to high priority items.

\subsection{PROGRAM CHALLENGES}

The mission analysis and development of an optimal solution for SST waste retrieval is complicated by a number of constraints and uncertainties. The most significant constraints and uncertainties are presented here.

Programmatic Uncertainties

- Retrieval End State (Retrieval Performance Criteria): The amount of residual waste permitted for closure of SSTs, if any, has not been established. The end state will be established by the National Environmental Policy Act of 1969 (NEPA) Closure EIS and Resource Conservation and Recovery Act of 1976 (RCRA) Closure Work Plan process, and is not expected to be complete before 2005. This uncertainty impacts selection of retrieval equipment and may result in more than a single retrieval campaign in a tank if retrieval begins before establishment of the end state criteria.

- Immobilization Facility Availability and Capacity: Decisions on when immobilization will start, rate of waste feed to facility, and facility performance will impact SST retrieval. 
HNF-2944

Revision 0

Programmatic Constraints

- Tri-Party Agreement Milestone Compliance: Retrieval system selection, design, construction, and deployment for several SSTs must be carried out to conform to Tri-Party Agreement milestones prior to finalizing the retrieval end state.

Physical Constraints

- Double-Shell Tank Storage Space: The available DST space to receive retrieved waste from SSTs limits the retrieval rate of SSTs.

\section{Technical Uncertainties}

- Waste Composition: Incidental blending resulting from simultaneous multiple retrievals provides a reasonably uniform waste feed, but blending requires knowledge of waste compatibility and composition. Limited information for current SST waste composition complicates waste compatibility decisions.

- Tank Integrity: 67 of the 149 SSTs are assumed to have leaked. Some of the remaining 82 tanks might leak waste during water-based retrieval. That waste along with waste already leaked could impact the workers, the public, or the environment. 
HNF-2944

Revision 0

This page intentionally left blank. 


\subsection{MISSION ANALYSIS}

This section defines (1) the SST retrieval problem in terms of initial-state and desired end-state conditions, (2) the mission statement, (3) primary functions and requirements, (4) key constraints and assumptions, (5) system boundaries and external interfaces, (6) the test and evaluation methodology, and (7) measures of success for the mission.

\subsection{PROBLEM DEFINITION}

The Hanford SST storage system has exceeded its design life and has leaked high-level radioactive and mixed wastes into the subsurface soils beneath the tanks. These wastes are migrating toward the groundwater. The potential for continued degradation of the SST storage system and subsequent leakage of stored wastes has raised concerns about future risks to the public health and the environment. The TWRS EIS (DOE and Ecology 1996) concluded that waste should be removed from these tanks.

The problem to be addressed by the SST Retrieval Program is to retrieve and transfer the wastes from the SSTs in a manner that is safe, cost-effective, and compliant with regulations.

The SST waste storage system does not comply with the State of Washington laws applicable to tank storage systems (WAC 173-303-640) that implement the RCRA treatment, storage, and/or disposal (TSD) requirements. In response to this and other deficiencies, Ecology, EPA, and the U.S. Department of Energy, Richland Operations Office (RL) negotiated the Tri-Party Agreement (Ecology, EPA and DOE 1996). The Tri-Party Agreement imposes retrieval requirements and schedules for remediating wastes stored in the SSTs.

The SST Retrieval Program must support Tri-Party Agreement Milestone M-45-05, which requires retrieval of waste from all 149 SSTs by September 30, 2018. The SST Retrieval Program must also provide sufficient waste feed to support the processing requirements of planned high-level and low-activity waste immobilization facilities (Payne et al. 1998). The waste immobilization facilities will be financed, built, and operated by a private contractor (Acree 1998). The DOE also intends to privatize the tank waste retrieval function, beginning in Fiscal Year (FY) 2012.

The SST Retrieval Program is challenged to provide the retrieval function in a costeffective manner before retrieval performance objectives are established through the Tank Closure (NEPA) process. 
HNF-2944

Revision 0

\subsubsection{Initial State}

This section describes certain initial conditions of the SSTs. Initial conditions described in this section may change before SST retrieval actions are initiated due to factors such as ongoing transfers of waste into and between tanks, construction of new equipment, and further deterioration of the tank systems.

2.1.1.1 Single-Shell Tanks. Mixed hazardous and high-level radioactive waste is stored in 133100 -series SSTs and 16200 -series SSTs. The SSTs are grouped into 12 tank farms. Figure 2-1 illustrates the basic structure of the 100-series SSTs. The capacities of the 100 -series SSTs range from $2,000 \mathrm{~m}^{3}(530,000$ gal $)$ to $3,800 \mathrm{~m}^{3}(1,000,000 \mathrm{gal})$. The smaller 200 -series SSTs have capacities of approximately $208,000 \mathrm{~m}^{3}$ (55,000 gal) (Hanlon 1998).

Waste storage capacity is required to contain the current waste inventories and new waste that will be generated as a result of retrieval and disposal operations, and other Hanford Site activities. Approximately $133,000 \mathrm{~m}^{3}$ (35 Mgal) of solid waste remains in the SSTs, with $87,000 \mathrm{~m}^{3}(22,926 \mathrm{kgal})$ as saltcake and $45,000 \mathrm{~m}^{3}(11,865 \mathrm{kgal})$ as sludge. The SSTs also contain $22,000 \mathrm{~m}^{3}(5,770 \mathrm{kgal})$ of pumpable liquid (Hanlon 1998).

Of the 149 SSTs, 67 SSTs have been assumed to have leaked. The 82 SSTs that have shown no evidence of leakage are assumed to be sound. A total of approximately $2.3 \mathrm{ML}$ to $3.4 \mathrm{ML}(600$ to $900 \mathrm{kgal})$ and $1.2 \times 10^{13}$ to $4.2 \times 10^{13} \mathrm{~Bq}(330$ to $1130 \mathrm{kCi})$ of ${ }^{137} \mathrm{Cs}$ have leaked into the surrounding soils (Hanlon 1997).

Of the 67 tanks that are assumed to have leaked, 51 have leaked less than $0.04 \mathrm{ML}$ (10 kgal) each, while two have leaked greater than $0.38 \mathrm{ML}(100 \mathrm{kgal})$ each. The largest single leakage is estimated to be $0.435 \mathrm{ML}(115 \mathrm{kgal})$. Figure $2-2$ depicts the numbers of tanks that have leaked waste within five leakage ranges.

Less than $10 \mathrm{Ci}$ of highly mobile radionuclides (e.g., ${ }^{99} \mathrm{Tc}$ ) from tank leakage are believed to have reached the groundwater below three tank farms (Hodges 1998, Johnson and Chou 1998, Narbutovskih 1998). This is being confirmed with additional monitoring and investigation.

Appendix A provides additional information on SST integrity and waste content. Appendix B provides information on SST system history and waste sources. 


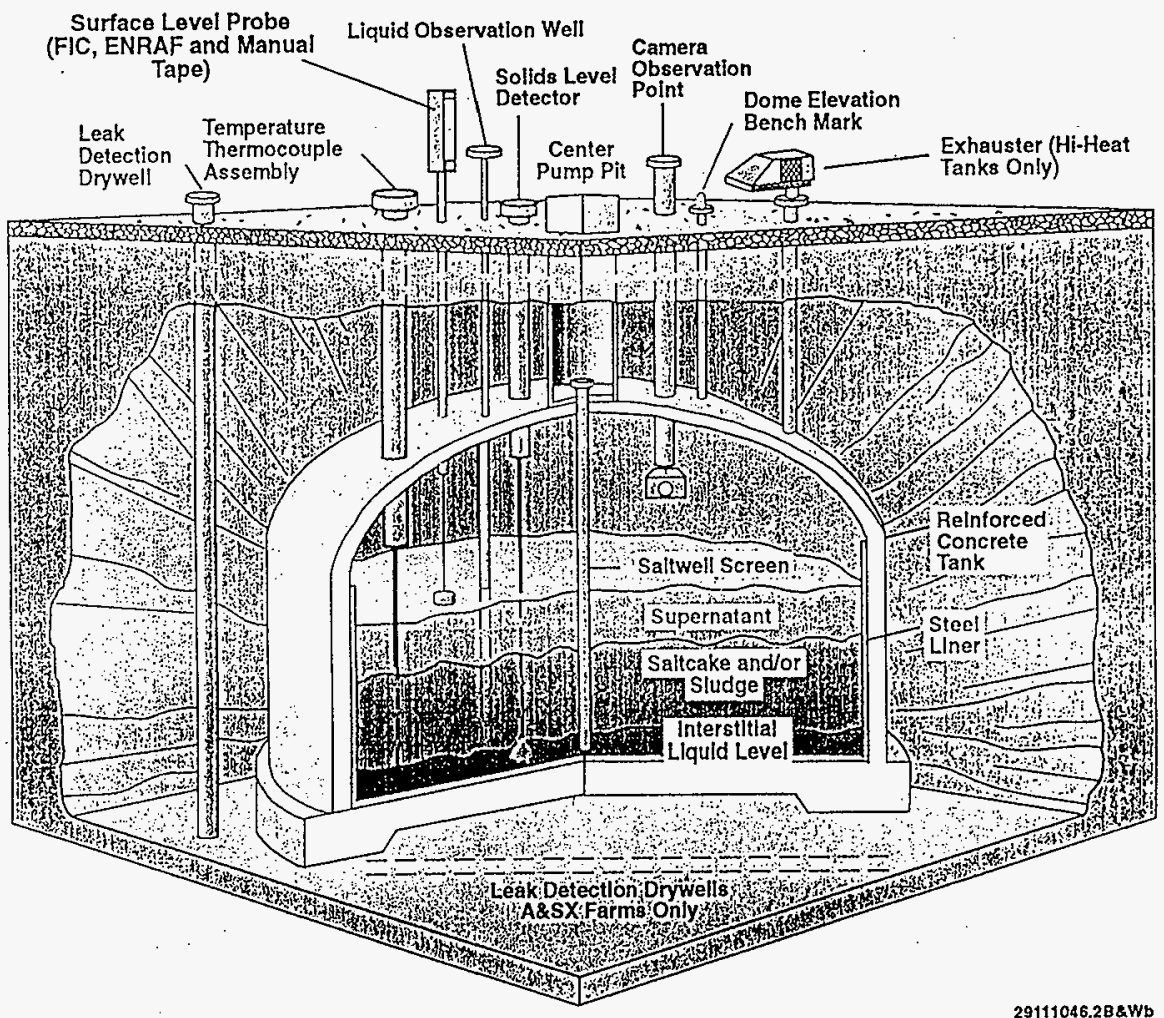


HNF-2944

Revision 0

Figure 2-2. Historical Tank Leakage.

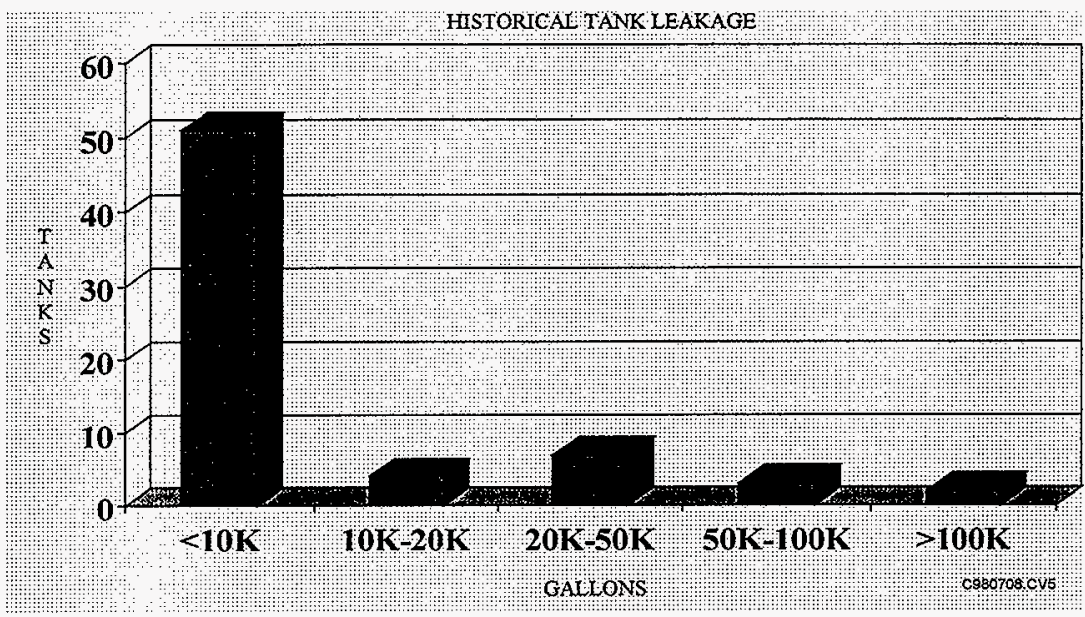

2.1.1.2 Miscellaneous Underground Storage Tanks. Retrieval of wastes in some Inactive Miscellaneous Underground Storage Tanks (IMUSTs) may be required by the SST Retrieval Program. The TWRS Project is responsible for remediating 48 Miscellaneous Underground Storage Tanks (MUSTs) used for (1) catch tanks, neutralization tanks, settling tanks, and receiving vault tanks; (2) handling waste in the tank farm system; (3) supporting uranium recovery operations; and (4) handling waste from non-TWRS facilities. The MUSTs vary in capacity from about 3,600 L (955 gal) to $190,000 \mathrm{~L}$ ( $50 \mathrm{kgal}$ ) and contain less than 1 percent of the waste in the Hanford underground storage tank system.

Of the 48 MUSTs, 36 are inactive (Brevick 1997 and Hanford Site Waste Information Data System [WIDS] [WIDS n.d.]). These 36 IMUSTs have been removed from service, most have had their inlet lines blanked, and most monitoring activities have been terminated. The remaining 12 active MUSTs support ongoing and future TWRS waste transfers and storage (Hanlon 1997, WIDS n.d.).

2.1.1.3 Existing Tank Waste Contents. Sodium salts represent the primary waste constituent and dominate the solids volume of tank waste. The nitrate ion $\left(\mathrm{NO}_{3}{ }^{-}\right)$, primarily in association with the sodium ion $(\mathrm{Na}+)$, constitutes the largest volume of hazardous chemicals in the tanks. Nitrates in the tanks are the dominant source of long-term groundwater risk (Hesser et al. 1995). The inventory of hydroxide ion $\left(\mathrm{OH}^{-}\right)$is used to control rates of in-tank chemical corrosion. 
Cesium-137 and ${ }^{90} \mathrm{Sr}$ (and equilibrium decay daughters), along with plutonium (Boothe 1995), dominate the current total waste radioactivity. These radioisotopes are the constituents of concern for external doses in accident analyses and worker exposures in analyses of normal operations. The tanks also contain small amounts of long-lived mobile radionuclides (e.g., ${ }^{99} \mathrm{Tc},{ }^{129} \mathrm{I}, \mathrm{U}$ isotopes, and ${ }^{14} \mathrm{C}$ ) that may pose future public health risks. Several SSTs contain waste types associated with unacceptably high temperatures, organic concentrations, and potentials for generating flammable gases. The tanks are equipped with real time monitoring for potentially hazardous conditions (Kincaid et al. 1998).

A detailed source of information on tank contents is the Standard Inventories of Chemicals and Radionuclides in Hanford Site Tank Wastes (Kupfer et al. 1997). This reference includes details about the inventory of radioactive and nonradioactive constituents contained in the SSTs and DSTs. Tables ES-1 and ES-2 of the Standard Inventories of Chemicals and Radionuclides in Hanford Site Tank Wastes (Kupfer et al. 1997) establish best-basis global standard inventories for nonradioactive and radioactive tank wastes. Tankby-tank inventories are being developed and documented in Tank Characterization Reports. These data can be obtained electronically through the Internet at the address http://twins.pnl.gov:8001/TCD/main.html.

\subsubsection{Single-Shell Tank Equipment and Other Waste Materials. Many SSTs contain} equipment and materials in addition to the typical waste materials (sludge, saltcake, and liquids). Equipment includes large installed hardware (e.g., airlift circulators, thermocouple trees, steam coils, and sluicers). Materials added to some tanks include experimental fuel elements, cobalt slugs, diatomaceous earth, Portland cement, discarded tank hardware, and miscellaneous small items.

\subsubsection{Contaminated Soil Conditions in Single-Shell Tank Farms. Soils surrounding} tanks in each SST farm have been contaminated as a result of tank leaks; transfer line leaks; tank overflows; surface spills; and intentional surface discharges into cribs, trenches and ponds. Each tank farm is contaminated, to varying degrees, by some combination of these events. Estimates of tank leak volumes and curies of ${ }^{137} \mathrm{Cs}$ leaked are reported in Hanlon (1998).

Historical gamma logging and more recent spectral gamma logging provide some indication of the concentrations and distributions of gamma-emitting contamination in SST farm soils. (Results and interpretations of spectral gamma logging are contained in a series of reports by MACTEC-ERS, e.g., GJO 1997, GJO 1998a,b). Many constituents of concern (e.g., ${ }^{99} \mathrm{Tc} ;{ }^{129} \mathrm{I}, \mathrm{U}$, and ${ }^{14} \mathrm{C}$ ) that are not measurable with gamma logging techniques are known to be present in tank farm soils; information on their concentrations and distributions is sparse. Some of the contamination that has leaked from SSTs may have reached the groundwater (Hodges 1998, Johnson and Chou 1998, and Narbutovskih 1998).

2.1.1.6 Status of Technology. Retrieval of SST waste using hydraulic sluicing has been successful in previous applications at the Hanford Site (Rodenhizer 1987). Advanced retrieval technologies and leak detection, monitoring, and mitigation technologies (LDMM) have been 
used or are under development at several DOE sites. The Tanks Focus Area, a DOEsponsored initiative, is investigating the nature of tank wastes across the DOE Complex and innovative methods for the retrieval and treatment of the wastes. At the Hanford Site, the Hanford Tanks Initiative (HTI) is developing and demonstrating advanced crawler-based waste retrieval technologies (Hendel and Schaus 1998).

\subsubsection{End State}

The end state for the SST Retrieval Program's mission (retrieve waste from SSTs) is the amount of waste that remains in the tanks following retrieval to allow closure. The TWRS EIS deferred development of closure criteria to the Closure NEPA process. Until this process is complete and appropriate retrieval performance criteria are established, the cleanup levels defined under Tri-Party Agreement Milestone M-45-00 will be used as interim targets. This milestone specifies that SST closure will follow retrieval of as much tank waste as technically feasible, with tank waste residues not to exceed $10 \mathrm{~m}^{3}\left(360 \mathrm{ft}^{3}\right)$ in each of the 100 -series tanks, $0.9 \mathrm{~m}^{3}\left(30 \mathrm{ft}^{3}\right)$ in each of the 200 -series tanks, or the limit of waste retrieval technology capability, whichever is less. The tank waste residue values represent approximately 1 percent of the existing SST waste.

Because the targets defined in Tri-Party Agreement Milestone M-45-00 may be superseded by new closure-based requirements (Tri-Party Agreement Change No. M-45-93-01), the acceptable end state for the SST Retrieval Program is defined as compliance with the waste retrieval requirements of the Closure EIS and associated Record of Decision.

\subsubsection{Mission Goals and Objectives}

Mission goals and objectives for the SST Retrieval Program include those delineated by DOE and those developed by the SST Retrieval Program to ensure compliant, cost-effective retrieval of wastes from SSTs and as required, the IMUSTs.

The following DOE goals and objectives (Taylor 1997) are directly applicable to the mission of the SST Retrieval Program:

- Consider risk reduction when selecting sequence and timing of SST retrieval.

- Approach SST waste retrieval and tank closure in a "learn as we go" manner, starting with the easier tanks first, progressing to the more difficult.

- Utilize retrieval technologies that address potential leakage during retrieval operations, including Leak Detection Monitoring and Mitigation System(s) and Advanced Retrieval Technologies. 
- Demonstrate SST retrieval methods for all waste types and tank conditions needed to prepare retrieval performance specifications for Phase 2 privatization.

Demonstrated SST retrieval methods should recognize efforts to quantify potential vadose zone and groundwater impacts from retrieval operations.

- Include any SST waste retrieval for Phase 2 feeds that may need to start early due to the logistics of a large number of tanks, and a large volume of waste that must be completed by 2018 .

- Minimize SST retrieval costs before Phase 2.

The following DOE goals and objectives (Taylor 1997) will be met by programs related to the SST Retrieval Program:

- Retrieve high-heat waste from tank 241-C-106 in accordance with the Multi-Year Work Plan, or sooner.

- Complete HTI technology demonstrations in tanks 241-C-106 and 241-AX-104.

- Provide feed to the privatized waste treatment and immobilization facilities as required to meet their processing schedule.

- Proceed with tank closure per the Tri-Party Agreement schedule as waste is retrieved.

The following internal SST Retrieval Program goals and objectives augment DOE's set of goals and objectives:

- Develop SST waste retrieval performance information and tools to support riskbased, cost-benefit decision making for key SST retrieval decisions.

- Determine the "limits of technology" to support development of performance criteria for SST retrieval system(s) under the Closure NEPA process and for the SST Farm RCRA Closure Plan(s).

- Retrieve sludge and saltcake from SSTs to achieve maximum risk reduction within the constraints of available waste storage space in DSTs and the Waste Disposal facilities and Tri-Party Agreement schedules.

- Develop a retrieval plan that supports efficient and effective utilization of infrastructure and supporting systems. 


\subsection{SINGLE-SHELL TANK RETRIEVAL PROGRAM MISSION STATEMENT}

The mission of the SST Retrieval Program is to safely retrieve tank waste from the 149 SSTs and applicable IMUSTs, and transfer the retrieved wastes to designated receiving tanks and facilities. Wastes in three SSTs will be retrieved by the Waste Feed Delivery Program, a related program responsible for retrieval activities supporting the waste immobilization private contractor during Phase 1. The SST Retrieval Program will be responsible for retrieval of wastes in the next 33 tanks. Wastes in the remaining SSTs will be retrieved by a private contractor.

SST retrieval activities will be conducted to: (1) prevent or minimize further contamination or threats to the vadose zone and groundwater quality, (2) meet waste feed delivery order quantities and schedules in support of the Phase 2 waste immobilization private contractor(s), (3) satisfy Tri-Party Agreement requirements, and (4) protect the public health, worker safety, and the environment.

\subsection{SINGLE-SHELL TANK RETRIEVAL PROGRAM FUNCTIONS AND REQUIREMENTS}

Primary SST Retrieval Program functions and requirements are defined in this section.

\subsubsection{Single-Shell Tank Retrieval Program Functions}

The SST Retrieval Program is a subset of the Tank Farm System (hsems.2.3.1), which in turn is an element of the Waste Retrieval Project (TW04) under TWRS. The upper-level function applicable to the SST Retrieval Program is tsd 2.2.6.2, "Retrieve SST Waste." The applicable subfunction for the SST Retrieval Program is tsd 2.2.6.2.1, "Remove Waste from the SST System." This function decomposes into "Retrieve Waste from SSTs" and "Transfer SST Waste." The SST Retrieval Program will provide the systems necessary to satisfy the "Retrieve Waste from SSTs" function for SSTs. The SST Retrieval Program will also satisfy part of the "Transfer SST Waste" function by providing systems for conveying the retrieved waste to Waste Receiving Facilities (WRFs) or DSTs. The Waste Feed Delivery Program will deliver the retrieved waste to the waste immobilization private contractor(s), thereby satisfying the remainder of the "Transfer SST Waste" function. 


\subsubsection{Single-Shell Tank Retrieval Program Requirements}

Selected Tri-Party Agreement Milestones that either directly or indirectly impose requirements on the SST Retrieval Program are shown in Table 2-1. The current complete list of Tri-Party Agreement Milestones related to the SST Retrieval Program is provided in Appendix C. The applicable Tri-Party Agreement milestones for the retrieval of wastes from SSTs begin with initiating retrieval of the first SST (241-C-106) in 1997 and end with completion of SST retrieval actions in 2018. The initiation of retrieval activities in tank 241-C-106 is currently scheduled for 1998 under the Waste Feed Delivery Program.

Table 2-1. Selected Tri-Party Agreement Milestones for Single-Shell Tank Retrieval.

\begin{tabular}{|l|l|l|}
\hline \multicolumn{1}{|c|}{ Milestone } & \multicolumn{1}{c|}{ Title } & \multicolumn{1}{c|}{ Date } \\
\hline M-45-01 & Develop Single-Shell Tank retrieval technology & $09 / 30 / 94$ \\
\hline M-45-03A & Initiate Sluicing Retrieval of 241-C-106 & $10 / 31 / 97$ \\
\hline M-45-03-T02 & Initiate Final Retrieval Demonstration of 241-C-106 & $06 / 30 / 02$ \\
\hline M-45-03-T01 & $\begin{array}{l}\text { Complete Single-Shell Tank Waste Retrieval } \\
\text { Demonstration }\end{array}$ & $09 / 30 / 03$ \\
\hline M-45-04-T01 & Provide initial Single-Shell Tank retrieval systems & $11 / 30 / 03$ \\
\hline M-45-05 & Retrieve Waste From All Single-Shell Tanks & $09 / 30 / 18$ \\
\hline M-45-00 & Complete Closure of all Single-Shell Tank farms & $09 / 30 / 24$ \\
\hline M-45-06 & $\begin{array}{l}\text { Complete Closure of all Single-Shell Tank farms } \\
\text { (Note: contains different scoping statement than M-45-00) }\end{array}$ & $09 / 30 / 24$ \\
\hline
\end{tabular}

Tri-Party Agreement Milestone M-45-00 also specifies retrieval of the equivalent of 99 percent of the waste or to the limit of the technology, whichever is less. See Section 2.1.2, End State.

DOE Planning requirements for the SST Retrieval Program follow. Other external requirements for the SST Retrieval Program are provided in Appendix D.

- Retrieval of SSTs will be initiated by December 2003 (DOE 1997a).

- Thirty-six SSTs will be retrieved by 2012 , including one complete farm; the remaining 113 SSTs will be retrieved by private contractors. All SSTs will be retrieved by 2018, and SST closure will be completed by 2024 (DOE 1997b). 
- Beginning in FY 2012, a private contractor will assume responsibility for operation, maintenance, and waste retrieval from SSTs and DSTs except for one tank farm from which waste retrieval operations are complete. This tank farm will be closed (DOE 1997b).

- The Project Hanford Management Contract (PHMC) Team will retrieve wastes during the transition of responsibilities from the PHMC to the private contractor(s) in 2011 (DOE 1997b).

- Tank Farm Operations Project facilities and utility and transfer systems shall be upgraded to meet current codes and standards to the extent practicable. Upgrades to selected facilities and systems will be performed to meet mission requirements and achieve a cost-effective, negotiated level of compliance (DOE 1997a).

\subsection{SINGLE-SHELL TANK RETRIEVAL PROGRAM CONSTRAINTS AND ASSUMPTIONS}

This section summarizes programmatic constraints and assumptions for the SST Retrieval Program. Constraints include physical, chemical, and radiological conditions that limit the range of application of systems that may be used for achieving mission objectives, whereas assumptions can be used to enable timely planning when critical information is not yet available.

\subsubsection{Program Constraints}

Conditions that constrain the retrieval of waste from SSTs are (1) the designs, capacities, and current conditions of the tanks and ancillary equipment; $(2)$ the characteristics of the waste, and (3) the limitations of the technologies needed to support retrieval. Constraints must be accommodated during the planning, design, and operational phases of the mission.

Requirements, addressed in Section 2.3.2, are not treated as constraints. Requirements include DOE policy, regulatory and safety limits, and design and construction standards and codes. Requirements must be satisfied rather than accommodated.

Constraints for this mission include the following:

- The limited available space in DSTs for storing retrieved SST waste and the large volumetric expansion of the waste that occurs during retrieval will constrain ability to conduct early retrieval of SSTs.

- The limited space between the top of the waste in some tanks and the dome of the tank, and the presence of numerous in-tank equipment items will impede installation and operation of retrieval equipment. 
- The limited number and size of available equipment access ports (risers) and limits on allowable tank dome loading will restrict the size and directly applied weight of retrieval equipment.

- Equipment obsolescence and deterioration (the design life of most tanks has been exceeded) will diminish potential uses of tanks and ancillary equipment.

- Equipment degradation caused by high radiation fields and operation in the mechanically-abrasive SST environment will limit life of candidate retrieval equipment.

- The following factors: (1) close proximity of tanks and associated aboveground instrument, electrical, and water service equipment; (2) inclement weather conditions (moderate to strong winds and temperature extremes); (3) limits of worker radiation doses; and (4) required radiation protection devices and methods (remote operating techniques and personal protective equipment), will impede construction, operations, and maintenance.

- Variability in waste chemical and radiological characteristics within individual tanks and from tank-to-tank will complicate the ability to satisfy waste feed delivery specifications.

- The presence of separated organic phases, high levels of transuranics (criticality concern), flammable gas evolution, and high heat in some tanks will complicate ability to safely retrieve wastes.

- The following factors: (1) hardened or congealed sludges that resist the water jet forces applied by sluicing; (2) rapidly settling solids that can settle before they can be pumped out the tank; (3) slow settling solids that can delay the start of waste transfers; and (4) formation of viscous gels or colloidal suspensions as the waste is diluted, may impede ability to satisfy waste feed delivery rate and tank clean-out requirements in some tanks.

\subsubsection{Program Assumptions}

\section{DOE Planning Assumptions}

DOE planning assumptions for the SST Retrieval Program include the following:

- Sluicing is used as the preferred SST waste retrieval method (DOE 1997b).

- Arm-based retrieval systems deploying confined sluicing or mechanical retrieval technologies are deployed in 50 SSTs (DOE 1998). 
HNF-2944

Revision 0

- Liquids are expected to be released from the SSTs during the implementation of any alternative that includes removing the waste from the tanks (DOE 1996).

- Each of the 149 SSTs would leak an average of $15,000 \mathrm{~L}$ (4,000 gal) to the soils surrounding the tank during retrieval operations (DOE 1996).

- If a leak were to occur during sluicing, the leakage volume would be expected to be 15,000 to $30,000 \mathrm{~L}(4,000$ to $8,000 \mathrm{gal})$ (DOE 1998).

- The current baseline detection and mitigation minimum leakage volume for SST retrieval operations is $30,000 \mathrm{~L}(8,000 \mathrm{gal})$ (DOE 1998).

- The contaminant concentrations in the liquids released would range from two-thirds to the maximum predicted concentrations (DOE 1996).

- Sluicing would remove all but one percent heel of waste from the tanks (DOE. 1996).

- The sluicing operation may not be able to remove sufficient waste to meet the removal requirements (DOE 1996).

- Waste will be retrieved only once from SSTs to a level sufficient to support closure (DOE 1997b).

- Residual waste remaining in the tanks after retrieval operations are completed, intank equipment, tank structures, and any underlying or adjacent contaminated soils will be disposed in place after suitable treatment (DOE 1997b).

\subsection{SYSTEM BOUNDARIES AND EXTERNAL INTERFACES}

This section describes the physical, organizational, and programmatic interfaces and boundaries that will exist between the facilities, components, utilities, materials, and services managed and/or supplied by Hanford Site programs and external organizations. The Hanford Site programs that support the overall SST cleanup mission include the following:

- Four programs under the SST Program (the SST Retrieval Program, the HTI, the Tank Closure Program, and the TWRS Vadose Zone Program)

- Waste Feed Delivery Program

- Characterization Program

- Interim Stabilization Program 
- Safety Issue Resolution Project

- Safe Storage Program

- Infrastructure Support Program

- Other Hanford Programs.

External agencies and organizations that will interface with the SST cleanup mission include the following:

- Washington State Department of Ecology

- Washington State Department of Health

- U.S. Nuclear Regulatory Commission (NRC)

- EPA .

- Office of Civilian Radioactive Waste Management (OCRWM)

- Occupational Safety and Health Administration

- Defense Nuclear Facility Safety Board

- Stakeholder Organizations.

Because the SST Retrieval Program is a sub-program under the Hanford Site cleanup mission, it must be fully integrated with the other Site cleanup programs to meet the overall goals and objectives of the Site Mission. Figure 2-3 shows the hierarchy among programs and other Hanford Site organizations that support SST retrieval.

The physical interfaces and boundaries with the SST Retrieval Program and related programs are described in the ensuing paragraphs. The SST Retrieval Program and the next three programs described below are the four programs that define the SST Program. The SST Program will focus on SST issues and the integration of SST activities conducted through other programs.

SST Retrieval Program. Waste contained in SSTs and applicable IMUSTs will be retrieved by the SST Retrieval Program. The SST Retrieval Program will plan and select the retrieval and LDMM technologies to be employed in SSTs, and conduct retrieval activities in those tanks. The SST Retrieval Program will also plan the retrieval sequence for the remaining SSTs that will be retrieved by a private contractor.

The SST Retrieval Program will interface with each of the programs identified in this section to ensure that (1) the waste is properly characterized to support selection of technologies and SST retrieval sequencing; (2) the necessary infrastructure upgrades and services are provided to support retrieval; (3) the appropriate technologies are selected and implemented; (4) the required amount of waste is retrieved; (5) the required air and subsurface monitoring is performed during retrieval; and (6) all safety and regulatory requirements are met. 
Figure 2-3. Hierarchy of Hanford Programs and Organizations that Support Tank Waste Remediation System Single-Shell Tank Retrieval.

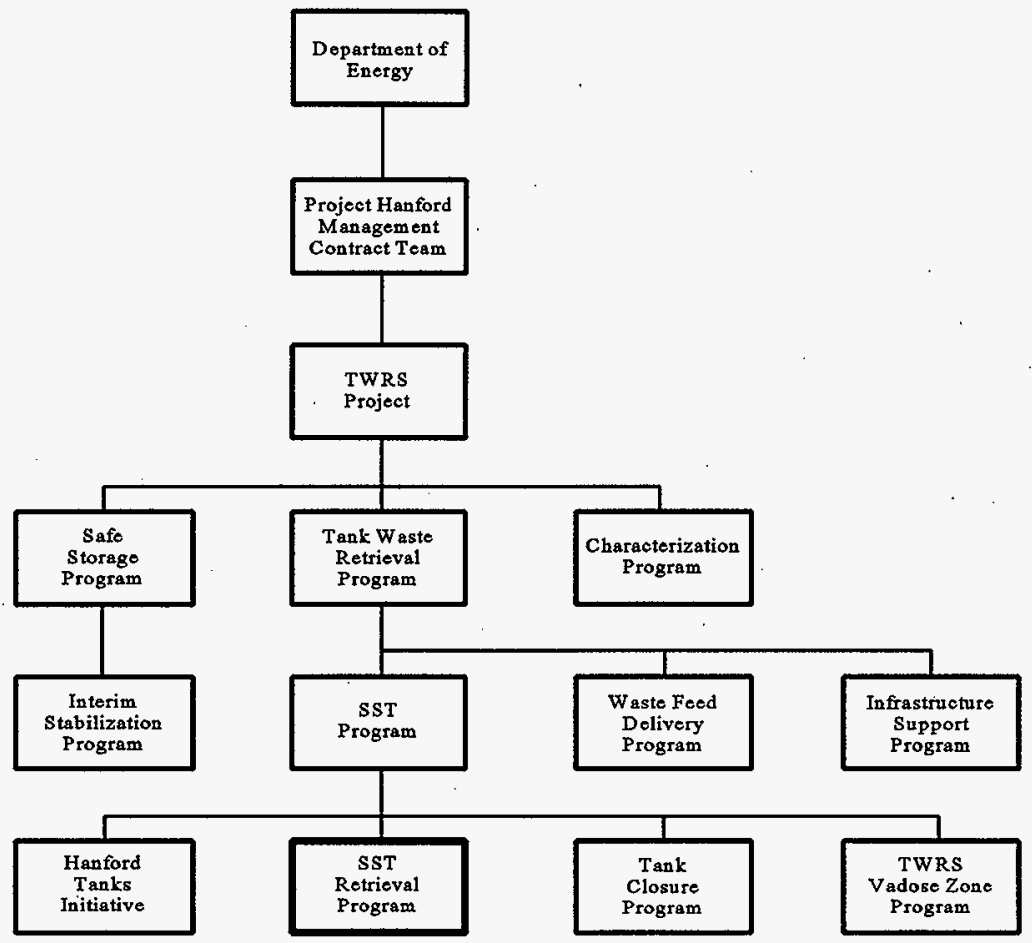


Physical program boundaries for the retrieval of the SST waste are confined to the SST tank, the DSTs into which the waste is retrieved, the WRFs, and the associated piping and infrastructure constructed and/or used by the SST Retrieval Program to retrieve the waste. Waste retrieval from pits, vaults, soil, piping, and support equipment is not within the scope of this program; this work will be the responsibility of the Tank Closure Program.

Hanford Tanks Initiative. Retrieval technologies will be demonstrated by the HTI. Final retrieval of wastes will be completed, as necessary, by the SST Retrieval Program. The SST Retrieval Program will define technology needs to be pursued by the HTI program. Successful technologies will become part of the SST Retrieval Program's technology baseline. Infrastructure upgrades to support technology demonstrations will be integrated with the existing infrastructure system and upgrades planned by the SST Retrieval Program. The HTI program will directly support and interface with the SST Retrieval Program.

Tank Closure Program. The SST Closure Program is responsible for planning and conducting tank closure activities. Waste transfer pipelines, pits, vaults, doublecontained receiver tanks (DCRTs), SSTs, IMUSTs, and ancillary equipment will be closed. Some contaminated soil resulting from leakage may also require retrieval prior to closure. Retrieval of contaminated soil, if necessary, would likely follow tank waste retrieval and deactivation activities conducted by the SST Retrieval Program. Certain tank and tank farm equipment, such as monitoring instrumentation and utility service upgrades provided by the SST Retrieval Program, may be used to support SST closure. The SST Closure Program will be responsible for the removal and disposal of equipment and systems used in the retrieval of the tanks.

TWRS Vadose Zone Program. TWRS cleanup decisions require an understanding of the effectiveness and the cost of measures that could be taken to avoid or limit the release or control subsurface movement of contaminants to avoid public health or ecological impacts, and contamination of the Columbia River. The TWRS Vadose Zone Program is developing the understanding of how contaminants move through the vadose zone. This understanding is important for decisions concerning existing contamination as well as contaminants released during or following cleanup activities, such as the following:

- Past leaks

- Potential leaks during retrieval

- Residual waste in tank farms at closure

- Onsite disposal facilities

- Other Hanford sources.

Waste Feed Delivery Program. Waste retrieved by the SST Retrieval Program will be conditioned and transferred to the waste immobilization private contractor(s) by the Waste Feed Delivery Program. Pipelines, pumps, and ancillary equipment for transferring the waste feed to the private contractor(s) will be provided by the Waste 
Feed Delivery Program. There are no direct interfaces with physical systems installed and operated by the SST Retrieval Program and those provided by the private contractor(s). The SST Retrieval Program will retrieve and transfer SST waste to DSTs and WRFs that it provides and/or uses. The Waste Feed Delivery Program will condition the waste as necessary and pump it to the private contractors via DST staging and feed tanks. The SST Retrieval Program will install additional piping, pumps, and equipment to support retrieval and integrate with the existing transfer system and new transfer equipment installed by the Waste Feed Delivery Program. DST space needs will be coordinated among the Waste Feed Delivery Program, the Interim Stabilization Program, the SST Retrieval Program, and the Safe Storage Program.

Characterization Program. Samples of SST waste will be taken and analyzed by the Characterization Program as required to support the SST Retrieval Program's selection of tank retrieval technologies and sequence for tank waste retrieval. Analyses of waste that remains in the tanks following retrieval actions taken by the SST Retrieval Program will support decision making regarding any additional retrieval that must be conducted by the SST Retrieval Program.

Interim Stabilization Program. Infrastructure upgrades required by the SST Retrieval Program will be integrated with upgrades required by the Interim Stabilization Program. DST space needs will be coordinated with the SST Retrieval Program and other user programs.

Safe Storage Program. New safe and compliant monitoring systems necessary to support operations under the SST Retrieval Program will be integrated with existing Safe Storage Program monitoring systems. These systems include in-tank instrumentation, air emissions, and vadose zone and groundwater monitoring systems. DST space needs will be coordinated with the user programs.

Infrastructure Support Program. Utilities (raw water, potable water, electricity, and sanitary services) and landlord services (general facility maintenance) will be provided to the SST Retrieval Program by the Infrastructure Services Contractor (DynCorp Tri-Cities Services Inc. [DynCorp]) through established and new infrastructure support systems. The SST Retrieval Program will provide funding for upgrading and extending utility systems to support retrieval and LDMM operations. Security services (fire protection, patrol) will be provided by the Safeguards and Security Contractor (B\&W Protec, Inc.). Solid waste disposition services will be provided by the Waste Management Project Contractor (Waste Management Federal Services of Hanford, Inc.) for long-length contaminated equipment, other failed or replaced equipment, contaminated soils, and general trash.

Other Hanford Programs. Other Hanford systems are required to support the overall Tank Waste Retrieval mission, but do not directly interface with the physical systems provided and operated by the SST Retrieval Program. These other systems include the private contractor's waste treatment and immobilization facilities, certain DSTs such as 
waste staging and feed tanks, the 242-A Evaporator or replacement evaporator provided by a private contractor, the Liquid Effluent Retention Facility and Effluent Treatment Facility, the Treated Effluent Disposal Facility, the State-approved Land Disposal Site, immobilized LAW storage/disposal facilities, and the immobilized HLW Canister Storage Building and storage modules.

In general, the remaining interfaces with the SST Retrieval Program are not physical, but support other organizations with the responsibility for direct interaction. Remaining interfaces include those with DOE; Fluor Daniel Hanford (FDH); Waste Integration Team (WIT); the private contractor(s); regulatory and other oversight agencies; stakeholders; and the general public. These interfaces are described in more detail in the Tank Waste Remediation System Program Plan (Freeman 1998).

\subsection{TEST AND EVALUATION METHODOLOGY}

Test and evaluation (T\&E) processes will include the set of activities that are performed throughout the life cycle of SST Retrieval Program to ensure that the end product of construction projects and facility operations meets mission objectives, functions, and performance requirements as defined in the Technical Baseline. The T\&E activities will begin early in the program planning phase and continue through design, construction and turnover to Tank Farm Operations.

A graded approach will be used to ensure $\mathrm{T} \& \mathrm{E}$ principles and practices are incorporated commensurate with project and program factors, such as complexity, visibility, and risk, to ensure successful project and program completion. The scope of T\&E activities includes the following:

- Concept and alternative validation testing performed during the initial design phase

- In-process inspection activities performed during the manufacturing and/or construction activities

- Vendor testing performed during process design, manufacturing, and construction

- Component post-installation acceptance tests and integrated system operational testing

- Functional testing, inspection, and maintenance performed during operational activities.

Key inputs to the $T \& E$ process will be the performance requirements for SST waste retrieval and transfer. These performance requirements will be derived from the mission, functional analysis, interface analysis and design requirements (laws and regulations, codes and standards, and organizational policies such as DOE Orders). Input will also be received 
from the HTI. The complete set of performance requirements will be developed. Once the performance requirements have been established, acceptance criteria will be developed to provide a performance measure that demonstrates that the item under test meets its performance requirements. Ácceptance criteria will provide measurability, quantification, completeness, currentness, accuracy, consistency, and traceability.

The T\&E plan will identify $T \& E$ activities that are required to verify that each performance requirement has been satisfied. Performance requirements will be verified through one or more of the following methods: modeling/analysis, laboratory process testing, in-field demonstration testing, in-process inspection, vendor testing, or post-installation acceptance and operational tests. Construction project T\&E reports should provide the traceability among the design requirements, $T \& E$ activities, and $T \& E$ results to demonstrate that the project end products comply with the Technical Baseline requirements.

\subsection{MEASURES OF SUCCESS}

The success of the SST Retrieval Program's mission will be measured by the following benchmarks:

- Begin retrieving waste from SSTs to support Phase 2 waste feed delivery requirements.

- Assess and demonstrate the limits of technology for various waste types.

- Retrieve waste from first "assumed leaking" tank.

- Provide sufficient retrieval data to support completion of Tank Farm Closure EIS.

- Provide sufficient retrieval system performance data to support development of a risk-based cost model for key SST retrieval and closure decision making.

- Retrieve wastes from SSTs, assuring that the required feed is available for delivery to the waste immobilization facilities.

- Complete waste retrieval from SST Tank Farms and applicable IMUSTs per TWRS EIS and Tri-Party Agreement requirements.

- Perform all work in compliance with applicable safety and regulatory requirements. 


\subsection{BASELINE ASSESSMENT}

This section summarizes the current baseline for the SST Retrieval Program. The baseline strategy is briefly described, along with the program approach that has been developed to implement the strategy. This section closes with a discussion of major concerns and impediments that have been identified for the current baseline, and which the alternative strategy, discussed in Section 4.0, is intended to resolve.

\subsection{CURRENT BASELINE}

The current baseline for the SST Retrieval program is driven by the retrieval milestones of the Tri-Party Agreement. These milestones begin the retrieval process with the initiation of retrieval of one SST by 12/2003 (M-45-05-T01). Each year through 9/2017, an increasing number of SSTs need to be retrieved. In 2015, 2016, and 2017, for example, retrieval of 20 additional SSTs must be started in each of those years. By $9 / 2018$, retrieval from all SSTs must be completed (M-45-05).

There is about $133,000 \mathrm{~m}^{3}$ (35 Mgal) of waste in these tanks and the preferred retrieval technique is sluicing (DOE 1997b). Sluicing will increase this volume to about $435,000 \mathrm{~m}^{3}$ (115 Mgal) (Payne et al. 1998). Existing DST space will be used to store/condition this waste. There will be limited DST space for the SST waste until the immobilization facility can process sufficient existing DST waste.

In formulating a SST retrieval mission analysis, there are three areas that require attention.

1. Uncertainties exist with retrieval endpoints (e.g., remaining waste in tanks, residuals) and retrieval requirements (e.g., DST available space) that impact the sequence of SST retrieval and the type of retrieval hardware to be used.

2. There is pressure from Tri-Party Agreement milestones and stakeholders to begin retrieving SSTs; but, at the same time, regulators and stakeholders also want to determine the amount of further tank waste leakage into the surrounding soil that will not pose a public health or environmental risk at the point of compliance.

3. Complying with the various Tri-Party Agreement milestones associated with SST retrieval, requires a huge logistical effort to retrieve tanks and to produce glass. In the timeframes required to meet regulatory milestones, the magnitude of such undertakings are unprecedented.

Efforts to resolve these issues directly influence the SST Retrieval baseline. Until these issues are addressed and firm decisions made, the SST retrieval baseline remains fluid. 
Figure 3-1 represents the current baseline for SST Retrieval. This baseline was presented in Kirkbride et al. (1997) and is consistent with the TWRS baseline as of June 1998. This sequence of tanks meets most of the Tri-Party Agreement retrieval milestones, and accommodates the available DST space and feed rates that the immobilization plants are expected to achieve. This figure shows the order of tanks to be retrieved, the duration of retrieval for each tank, and the various Tri-Party Agreement milestones for initiating retrieval. This baseline is derived from the waste processing rates shown in Figure 3-2, defined by DOE so the Tri-Party Agreement retrieval milestones can be met with existing DST space.

Figure 3-3 shows the rate at which SST waste volume is reduced for this retrieval sequence. In the early years (2004 through 2012) only 14 percent of the waste is removed from SSTs. The infrastructure required to achieve this retrieval rate is pictured in Figure 3-4.

This current baseline for the SST Retrieval Program shows clearly the factors that influence the retrieval schedule and sequence are the processing rate of the immobilization plant and its start date. In the absence of firm processing rates and start dates, other assumed processing rates would result in other SST retrieval baselines, influencing up or down the rate of SST retrieval, and impacting compliance with Tri-Party Agreement SST retrieval milestones. Even this optimistic and difficult to meet retrieval sequence misses the Tri-Party Agreement retrieval completion milestone (M-45-05) by one year. 
HNF-2944

Revision 0

Figure 3-2. Phase $1 \mathrm{~B}$ and Phase 2 Low-Activity Waste Processing Rates.

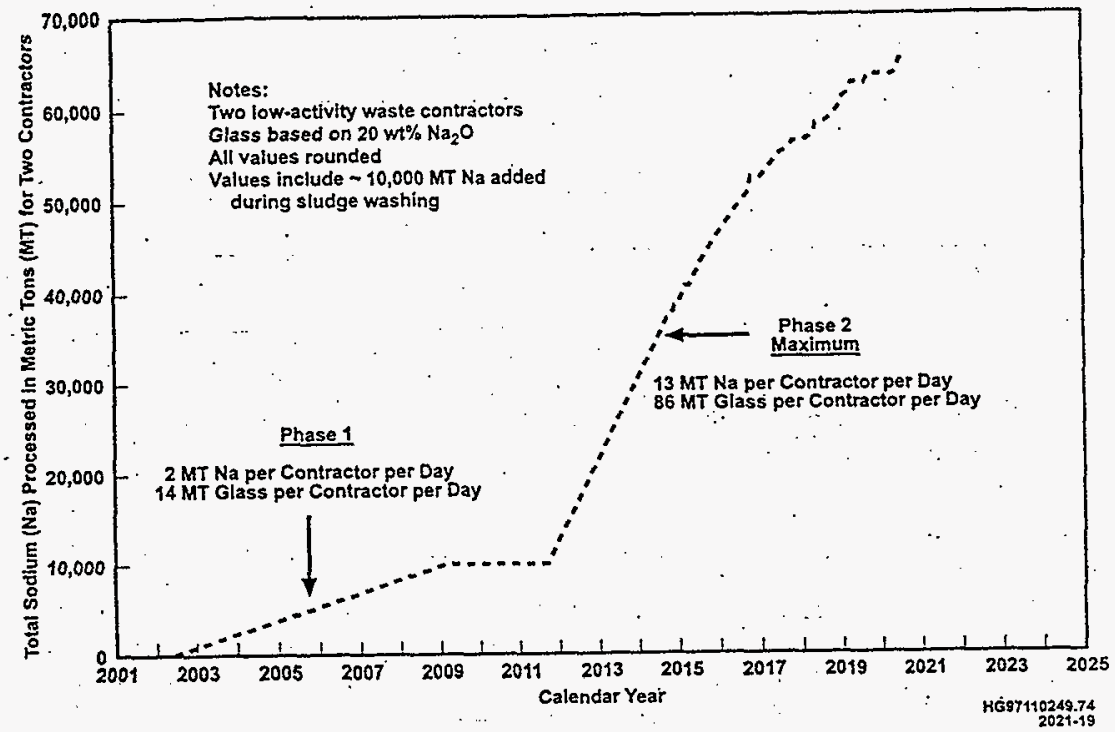


HNF-2944

Revision 0-Draft

Figure 3-3. Waste Volumes Remaining in Single-Shell Tanks Over Time.

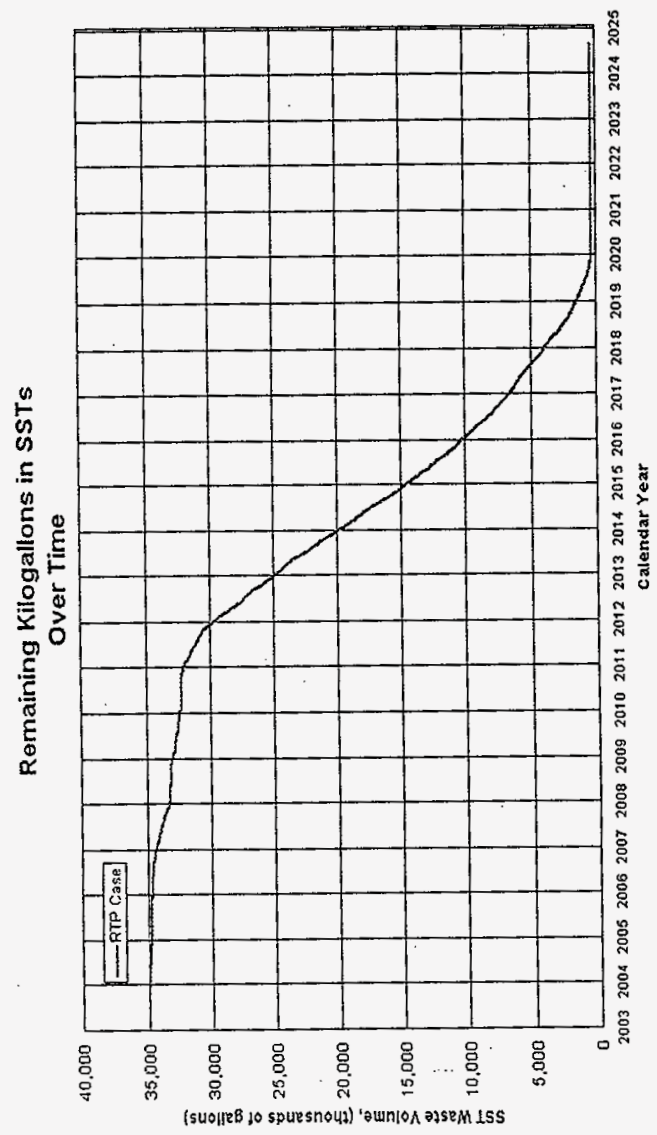


Figure 3-4. Tank Farm System Retrieval and Transfer Infrastructure.

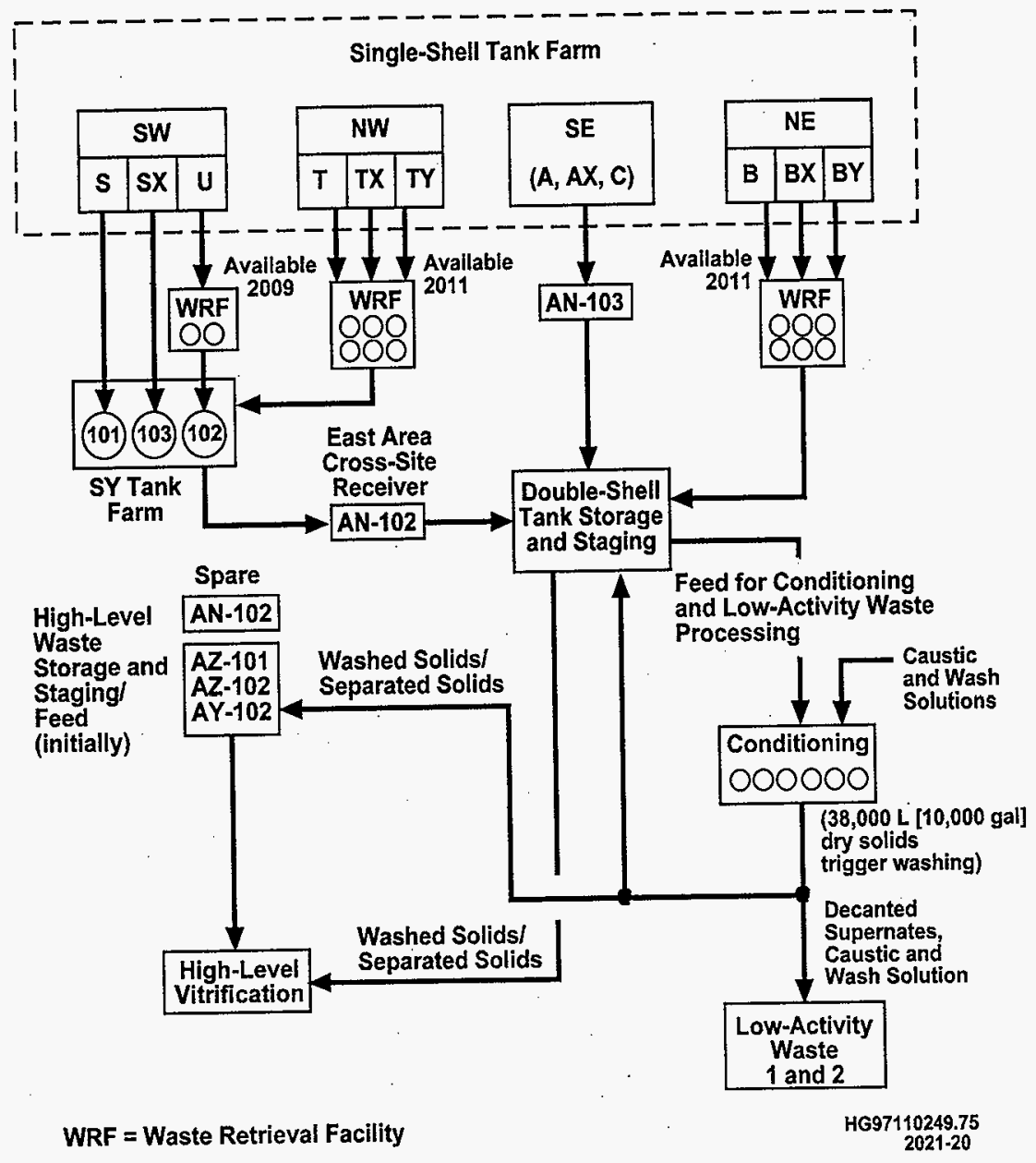


This baseline assessment used the TWRS MAR and the Tank Waste Remediation System Operation and Utilization Plan (TWRSO\&UP) (Kirkbride et al. 1997) as the reference for the baseline case. Any changes to the baseline suggested or analyzed during FY98 have not been factored into the baseline case presented in Section 3.0 of this MAR.

\subsection{REQUIREMENTS AND ASSUMPTIONS}

The current baseline described in Section 3.1 was constructed from requirements established by DOE and from assumptions formulated to accommodate areas with incomplete technical analysis or to overcome uncertainties. follows:

DOE requirements that directly influence SST Retrieval baseline development are as

- Retrieval of SSTs will be initiated by December 2003 (M-45-05-T01).

- Thirty-six SSTs will be retrieved by 2012 , including one complete farm; all SSTs will be retrieved by 2018, and SST closure will be completed by 2024 (DOE 1997b).

- Out-of-tank sludge washing will be carried out in Phase 2. Enhanced sludgewashed HLW solids will be provided to the Phase $2 \mathrm{HLW}$ plant. Phase 2 LAW plants will operate from 2011 through the completion of SST closure in 2024. The LAW plants will be sized to accept waste feed at a sufficient rate to accomplish SST retrieval by 2018 and SST closure by 2024 (DOE 1997b).

- In Phase 2, privatized contractors will start operations in 2011 and 2012 for LAW and HLW immobilization, respectively (DOE 1997b).

Assumptions used to create the current baseline are as follows:

- Past-practice sluicing is used as the preferred SST waste retrieval method (DOE 1997b); sluicing hardware will be reused.

- Past-practice sluicing would remove all but one percent of the waste from the tanks (DOE 1996).

- Tank waste leakage into surrounding soil will average $15 \mathrm{~m}^{3}$ (4,000 gal) during retrieval; leak detection, monitoring, and mitigation methods will be available to assure control of larger leaks (DOE and Ecology 1996).

- Waste will be retrieved only once from SSTs to a level sufficient to support closure (DOE 1997b). 
- SST retrieval sequence is influenced by: (1) saltcake versus sludge content of each tank; (2) total sludge volume for an individual tank; (3) total retrieved waste volume for an individual tank; (4) inventory of glass limiting components; (5) minimizing glass volume; (6) designation as a watch list tank; and (7) having AX farm retrieved before 2011 to support tank farm closure demonstration (Kirkbride et al. 1997).

- Phase 2 retrieval sequence and blending strategy does not target specific envelopes but emphasizes simultaneous retrieval and intermediate storage in WRFs to create blended feed (incidental blending) (Kirkbride et al. 1997).

- The global tank inventory (after correction for Phase 1B feed) is retrieved as a uniform $5 \mathrm{M}$ Na slurry; necessary characterization is available to resolve waste compatibility issues upon blending (Kirkbride et al. 1997).

- Retrieve into a single receiving tank from a single SST to enhance ability to detect a leak in the sluicing system (Kirkbride et al. 1997).

- Saltcake and sludge will be retrieved from the SSTs at the rate of $7.2 \mathrm{~m}^{3} /$ day when the tank waste volume is greater than 10 percent of the tank volume and $0.72 \mathrm{~m}^{3} /$ day when the waste levels are below 1 percent of the tank volume. Between 1 percent and 10 percent of the tank volume, the retrieval rate decreases from 7.2 to $0.72 \mathrm{~m}^{3} /$ day. An equivalent average retrieval rate was calculated for each SST based upon the waste inventory to simplify calculations in the HTWOS model (Kirkbride et al. 1997).

- There is no limit on the number of simultaneous transfers in the combined SST/DST system (Kirkbride et al. 1997).

- Three WRFs are required; the WRFs will be available January 1, 2011; the WRF for $U$ tank farm will be available January 1,2009 , to allow maximum retrieval before FY 2011 (Kirkbride et al. 1997).

- No additional DST storage will be built; all 28 DSTs will be available throughout the SST retrieval program for various uses in accordance with OWVP assumptions and none are lost to corrosion (DOE 1997b).

- During Phase 2, the private contractor(s) will utilize their own facilities to perform sludge washing to pretreat sludge (i.e., the 28 DSTs will not be used). This has been referred to previously as out-of-tank sludge washing (Kirkbride et al. 1997).

- For the purpose of evaluating alternative retrieval sequences, Tri-Party Agreement milestones M-45-05-T01 through M-45-05-T15 will be negotiable with other measures and metrics including, but not limited to, cost profile, interim storage risk, and HLW glass volume (Kirkbride et al. 1997). 
- Needed and multi-year funding stability are available for capital projects; tank farm hardware and upgrades are available on schedule

\subsection{ISSUES}

The baseline established in Section 3.1 highlights that SST retrieval on a schedule reasonably consistent with current Tri-Party Agreement retrieval milestones is possible. Section 3.2 identifies all the enabling assumptions needed to meet those retrieval milestones. A substantial number of these assumptions will be difficult to achieve even under optimal conditions.

There are large programmatic risks associated with achieving this current baseline. Many of these were identified in the Management Assessment of Tank Waste Remediation System Contractor Readiness to Proceed with Phase 1B Privatization (Payne et al. 1998). The following are some important issues that require early attention and resolution:

- The Tri-Party Agreement milestone of 2018 to complete SST retrieval cannot be met (missed by one year) under current technical and programmatic conditions. Under this current baseline, the ability to meet these ambitious retrieval rates and glass production rates have large programmatic risks.

- Currently planned sluicing retrieval technology may result in additional contamination of the surrounding soil if applied to tanks that have leaked or may leak during retrieval.

- Establish the amount of residuals, if any, allowed. Sluicing may not remove 99 percent of waste. In addition to sluicing technology, other retrieval technologies may need to be deployed to meet this residual target.

- The current immobilization schedule assumes a large tamp up in production beginning in 2012; the technology to make the daily volume of glass (unless there is a break through) will require parallel production lines; parallel lines to produce 200 MT of glass per day will impose huge logistical issues.

- The current rate of SST retrieval using sluicing (up to 10 tanks simultaneously and about 15 tanks per year beginning in 2011) is probably not practical.

In the remainder of this SST Retrieval Mission Analysis, approaches are suggested to accomplish the following:

1. Increase earlier the amount of DST waste immobilized to free up more DST space, so SST retrieval can operate at a faster rate. 
HNF-2944

Revision 0

2. Modify the SST retrieval sequence to reduce the likelihood of increased contamination of the soil around the tanks and reduce substantially the inventory of those radionuclides that pose the largest threat to the public and environment, while effectively utilizing available DST space (Track 1, see Section 4.0).

3. Generate the information needed to make earlier decisions on the amount of residual waste, if any, in SSTs and the additional amount of contamination in the surrounding soil (Track 2, see Section 4.0).

These alternative approaches to the baseline SST Retrieval Program will simplify the huge logistical issues associated with simultaneous retrievals and the large number of retrievals per year. The alternative approach will also draw attention to the unrealistic immobilization facilities needed to achieve the current baseline production rates. 
HNF-2944

Revision 0

This page intentionally left blank. 


\subsection{ALTERNATIVE SINGLE-SHELL TANK RETRIEVAL STRATEGY}

This section describes a proposed alternative strategy for SST retrieval that balances the need for additional information on technical and programmatic uncertainties, the requirement for feed delivery to the waste immobilization facilities and the provisions of the Tri-Party Agreement to proceed with waste removal and tank closure.

\subsection{ALTERNATIVE STRATEGY}

This section presents the alternative strategy, demonstrates the technical feasibility of the approach, and describes the basic planning for implementing this alternative strategy.

\subsubsection{Foundation}

In evaluating the current baseline, the mission analysis has identified programmatic uncertainties, physical constraints, and technical uncertainties which challenge the baseline system's opportunity for success. Despite these uncertainties, the SST Retrieval Program is chartered to meet annual retrieval initiation and completion schedule requirements specified in the Tri-Party Agreement. The Program must also provide waste feed to the immobilization facility in accordance with delivery specifications, complete the mission in a cost-effective manner, and minimize the risk to the public and the environment from potential retrieval leaks. The Tri-Party Agreement and feed elements are discussed in Section 3.0.

A significant programmatic uncertainty is the lack of a defined SST end-state for tank and tank farm closure and associated retrieval system performance criteria. The SST end-state conditions will be established through the NEPA process followed by preparation and approval of a closure plan meeting WAC 173-303-610 requirements. The retrieval system performance criteria, which are derived from a closure NEPA process will not be finalized until approximately 2005 . This uncertainty in performance criteria affects the following:

- Retrieval System Design

- Retrieval Technology Selection

- Leak Detection Technology Selection

- Infrastructure Upgrades for Retrieval

- Retrieval Program Cost Management.

The most significant physical constraint for SST retrieval is the limited storage space in the DST system. Availability of DST space is controlled by specifications on inventory management, waste segregation, and design processing rate and schedule of the privatized waste immobilization facilities. The current DST system configuration and planning assumptions affect the following: 
- DST space management

- Stored waste type segregation

- Immobilization facility schedule

- Immobilization processing rates

- Feed delivery requirements from SSTs.

The current SST retrieval baseline does not meet Tri-Party Agreement milestone requirements for completion of SST waste retrieval (M-45-05).

The SST Retrieval Program is also challenged by technical uncertainties related to tank waste composition, radionuclide inventories, tank integrity, tank internal obstructions, and ability to assess the public and environmental impacts of potential leaks. These technical uncertainties affect all aspects of the SST Retrieval Systems design process.

The alternative strategy was developed in recognition of the need to begin retrieval activities to meet Tri-Party Agreement milestones and support feed delivery requirements in parallel to efforts to resolve the programmatic and technical uncertainties which are necessary to support the endpoint determination and optimize the program for risk reduction and cost effectiveness.

\subsubsection{Approach}

The SST Retrieval Program approach to development of an alternative strategy to resolve or mitigate the issues facing tank retrieval, was developed on the following premise:

1. Given the need to proceed with retrieval, to:

- Meet Tri-Party Agreement milestones

- Provide waste feed to the immobilization facility

- Prevent additional releases to the environment from aging SSTs, and

2. Without a clear understanding of:

- Endpoint or risk-based retrieval criteria for each tank and tank farm

- The potential for tank leaks during retrieval

- Public health and environmental impacts of leaks

an optimized strategy for completion of SST mission cannot be developed. 
3. Recognizing these limitations, the proposed strategy allows the following:

- Begin retrieval in a way that poses minimum risk to the worker and the public, or of additional environmental impacts.

- Meet waste feed delivery requirements to the privatization contractor.

- Provide information to support decision plans on endpoints and technology selection for the optimizing retrieval program plans.

- Develop the necessary technical input to support the NEPA process.

The mission analysis approached development of an alternative strategy through an assessment of the current status of SSTs, information needed to accomplish the mission and information currently available. Through this assessment, an approach evolved which utilized the information known about tank integrity, leak history, retrieval technologies, and tank inventory to formulate a path forward for retrieval of tanks believed to be sound, using technologies that minimize the potential leak volume during retrieval.

In addition to opportunities to proceed with retrieval, the mission analysis identified several areas which require further investigation and information development. Additional information is required to support the regulatory processes for end-state determinations, analysis and investigations are required to develop accurate models for management of risk to the public and environment from potential retrieval leaks, and technical data development to support technology selections for final retrievals, if required, and retrieval of waste from leaking or damaged tanks. In parallel with initiation of selected retrievals, the strategy proposes a methodic approach for identification and development of information needed to support the regulatory processes and complete the SST Retrieval Program mission.

Once retrieval system performance requirements are established through the NEPA and closure planning processes and technologies necessary for criteria compliance and retrieval of tanks that have leaked are demonstrated, the SST retrieval processes will be optimized for cost, performance, and risk reduction. The strategic approach described above to the development of an SST Retrieval Program which is responsive to Tri-Party Agreement milestones and waste feed delivery requirements is depicted in Figure 4-1. 
HNF-2944

Revision 0

Figure 4-1. Single-Shell Tank Retrieval Program Strategy.

Current Status

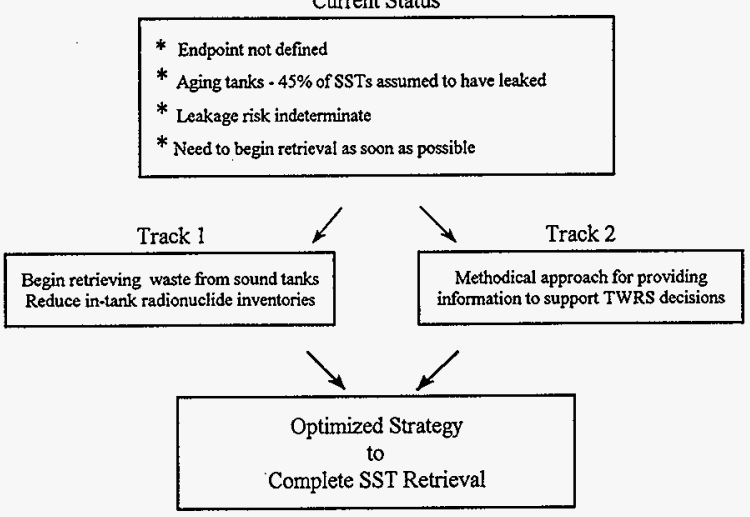

\subsubsection{Strategy Description}

The alternative strategy proposed for the SST Retrieval Program is based on a two-track approach. The strategy is designed to begin retrieval of SST wastes while supporting development of information in other TWRS and SST programs needed for key programmatic decisions regarding optimization of SST waste retrieval and tank and tank farm closure.

The first step taken in the development of the alternative SST Retrieval Program approach was to analyze the mission and evaluate the existing information. In performing the Mission Analysis many of the existing baseline assumptions and requirements were reevaluated. This process confirmed that a significant amount of information is available to support initial retrieval decisions and provide confidence in proceeding with retrieval under specified conditions.

The key elements of Track 1 are as follows:

- Retrieve wastes from sound SSTs.

- Provide feed for waste immobilization contractor.

- Meet Tri-Party Agreement commitments and milestones.

- Apply simple low hydraulic head, water-based technologies for tanks with significant inventories of readily retrievable wastes.

- Select tanks and technologies to minimize leak potential and implications. 
The ability to carry out Track 1 is supported by available tank content and integrity information, see Appendix A, which indicates there are a number of sound tanks with significant waste inventories, which could be retrieved safely using simple, hydraulic technologies and presently available leak detection technologies. A retrieval plan, focused on these tanks, would reduce SST waste inventories, reduce risk from potential future tank leaks, and could be managed so as not to pose an undue risk to the public or environment while making progress on SST remediation.

Under the Track 2 near-term strategy, the SST Retrieval Program will provide retrieval and leak detection technology performance data necessary for key programmatic decisions. Initial retrieval actions will be designed to provide information or data on the following:

- Advanced retrieval technology performance or performance requirements

- Leak detection and mitigation technology performance or performance requirements

- Technology performance to support closure requirements

- Leak mitigation and cleanup experience

- Cost performance for risk-based cost-benefit assessments.

These data, when used with information developed by other TWRS programs, will support the resolution of uncertainties and optimize the retrieval program.

An optimized Program Plan will be developed through the maturing of technology performance data and predictive models for risk assessments though historical and investigative data, which from the basis of the risk-based, cost-benefit decision making and establishment of retrieval performance criteria to support the Closure Program. The long-term program strategy is to optimize the retrieval process systems designs and performance criteria on riskbased, cost-benefit techniques. The programmatic approach to the SST Retrieval Program, identifying primary program activities and informational needs, is depicted in Figure 4-2. 
Figure 4-2. Single-Shell Tank Retrieval Program Approach.

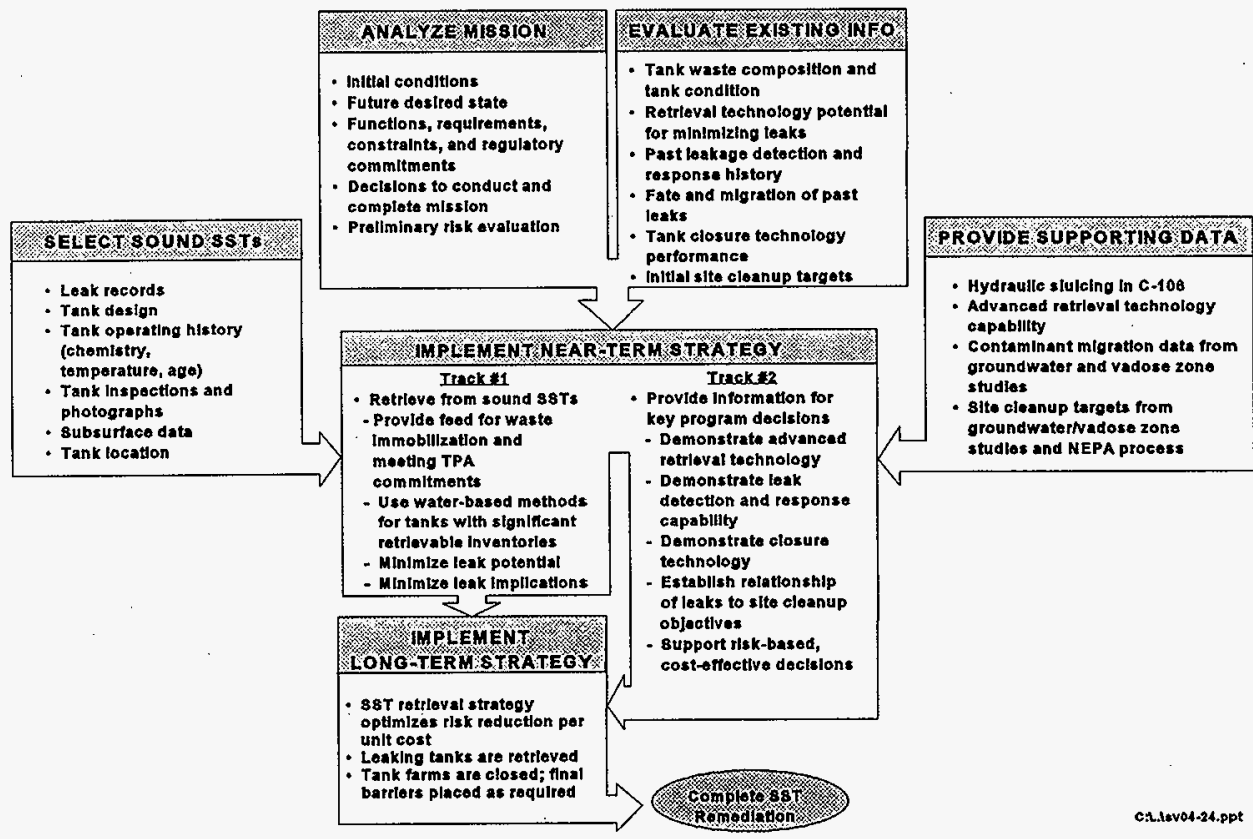




\subsubsection{Feasibility of Approach}

The mission analysis assessed four principal elements of the alternative strategy as a basis for determining the feasibility and benefit of the approach. This effort was an assessment of feasibility and not an attempt to plan the program. As such, constraints such as DST space availability, are identified but not resolved in this assessment. Resolution or mitigation of the program challenges constraining initiation of SST retrievals will be addressed in the development of the program work plan.

The elements selected to demonstrate the feasibility and benefit of the alternative strategy are discussed below. These elements support the approach to proceed with retrieval prior to resolution of all program uncertainties. The elements were assessed using the tank inventory and integrity information presented in Appendix A.

- Availability of sound tanks for retrieval while Track 2 resolves programmatic and technical uncertainties

- Waste volume and content are available for retrieval from sound tanks to support waste feed delivery requirements of the immobilization facilities

- Availability of low-risk retrieval technologies and leak detection technologies to support retrieval of bulk wastes from tanks considered sound

- Public benefit achieved by proceeding with initial retrievals in light of potential added costs for multiple retrieval campaigns to meet closure retrieval criteria.

Although a potential technical approach may be identified for each element demonstrating feasibility, solutions to program constraints (e.g., availability of DST space and immobilization facility processing rates and schedule) will be required for effective implementation of the proposed alternative strategy. These program constraints are key inputs to this SST retrieval strategy.

Specifically, under the current system configuration and baseline assumptions, the rate of SST waste retrieval is constrained by available DST storage space. Resolution or mitigation of this issue through adjustments in DST management assumptions, changes in assumptions in waste immobilization facility operating parameters, the addition of supplemental DST storage space, or other technology approach to waste volume reduction will be required to effectively implement the proposed alternative strategy. Such issues will be addressed in the work plan development.

Note, the data presented in the graphs (Figures 4-3 and 4-4) in the following sections were developed solely from Tri-Party Agreement milestone perspective and do not take into account the constraints of the infrastructure issues, DST space, or waste feed segregation requirements. These charts are provided for illustrative purposes only to demonstrate program opportunity. 
4.1.4.1 Availability of Sound Tanks. The SST retrieval alternative strategy is based on minimizing the public and environmental risk from potential tank leaks during retrieval operations by proceeding with retrievals from those tanks which are considered sound and contain the majority (64 percent) of waste inventory (Hanlon 1998).

Although there are uncertainties regarding the integrity of tanks considered sound, the use of low hydraulic head retrieval technologies to eliminate or minimize the required hydraulic driver for leakage supports the technical basis of this approach. In reviewing the availability of sound tanks for retrieval, the data presented in Figure 4-3 demonstrates that the SST system contains a sufficient number of sound tanks to support Tri-Party Agreement retrieval milestone requirements through 2014. This is not to imply that only sound tanks will be retrieved first, but rather the approach provides the opportunity to progress with retrieval while technology and information needs necessary to retrieve tanks assumed to have leaked are developed.

Figure 4-3. Single-Shell Tank Retrieval Initiation.

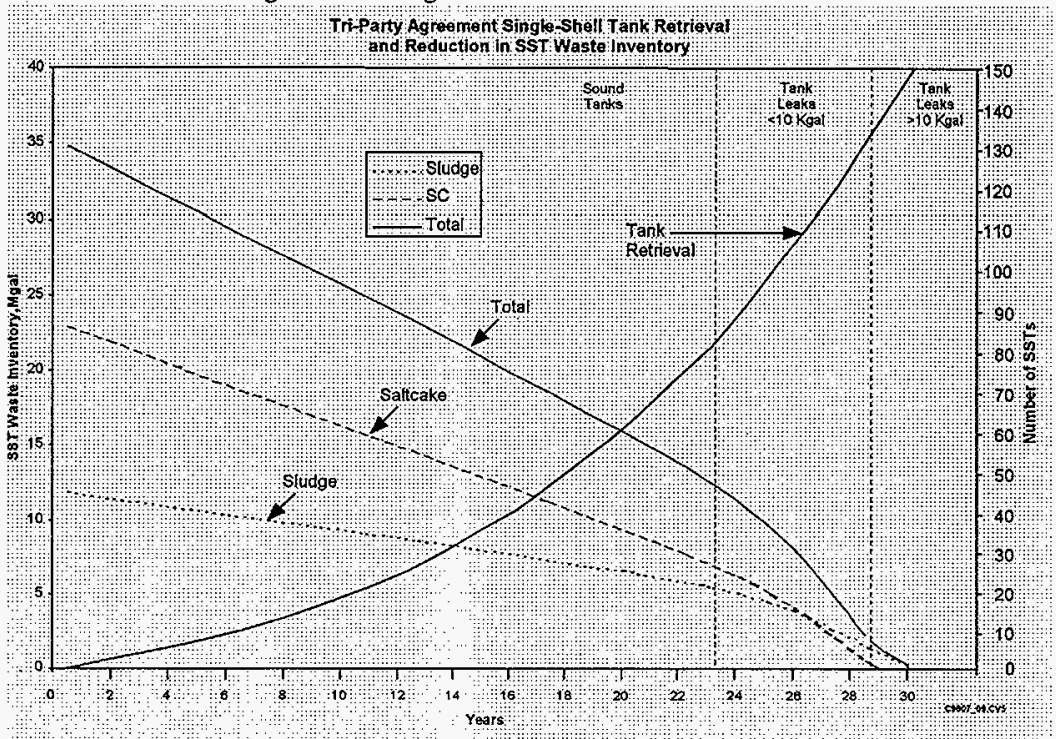


A further review of the data presented in Appendix A, indicates that the SST system contains 13 sound tanks, whose primary inventory is salt cake and which have yet to be interim stabilized. Preliminary testing at Savannah River indicates this material to be highly soluble and retrievable using simple, low hydraulic head, water dissolution technologies. One conceptual approach for such a system utilizes a very low-rate, simple water addition system with the existing interim stabilization equipment and infrastructure to remove saltcake waste forms (Wiersma 1996).

\subsubsection{Projected Leakage for Tanks Assumed to be Sound. Under this alternative} strategy, tanks assumed to be sound (i.e., no indication of past leaks) would be the first tanks to be retrieved. The ability to begin retrieval from such tanks relies on the belief that possible leaks during retrieval from sound tanks using hydraulic approaches would not have catastrophic consequences for groundwater and public health and the environment. Prior to development of risk based leak impact criteria, this belief is based upon (1) the use of low water volume technologies (i.e., minimizing potential leak volume) and (2) historic information for tank leak rates (i.e., the likely rate of liquid loss).

Leak rate data have been statistically analyzed to identify the maximum probable leak rate from a single shell tank (Isaacson and Gasper 1981). Five confirmed tanks that have leaked had leak rates ranging from $0.3 \mathrm{~mL} / \mathrm{s}(0.005 \mathrm{gal} / \mathrm{min})$ to $1.5 \mathrm{~mL} / \mathrm{s}(0.023 \mathrm{gal} / \mathrm{min})$. Six tanks of questionable integrity were also included in the analysis. These tanks had leak rates ranging from $0.095 \mathrm{~mL} / \mathrm{s}(0.0015 \mathrm{gal} / \mathrm{min})$ to $1.3 \mathrm{~mL} / \mathrm{s}(0.020 \mathrm{gal} / \mathrm{min})$.

Reviews of historical leak rates in 1981 (Johnson 1995) revealed that excluding tanks 241-T-106 and 241-SX-110, which experienced significant leakage rates due to suspected structural problems, the maximum leak rate was estimated to be $0.11 \mathrm{~L} / \mathrm{min}(<0.03 \mathrm{gal} / \mathrm{min})$ at a 95 percent confidence interval. This equates to $163 \mathrm{~L} /$ day $(43.2 \mathrm{gal} /$ day) or $4,900 \mathrm{~L} /$ month $(1,296 \mathrm{gal} / \mathrm{month})$. Clearly, at these rates it takes a considerable time period without an operational response to leak large amounts of liquid from an SST during retrieval. This historically low leak rate supports the feasibility of starting the SST retrieval program with tanks which have been declared sound (Hanlon 1998).

If past-practice sluicing were used, historical leak rates and the quantities of waste to be retrieved indicate the likelihood of a leak exceeding the maximum detection level during sluicing retrieval is very low. (It was calculated that an average leak would likely not exceed $780 \mathrm{~L}$ (207 gal), while a maximum leak would likely not exceed 4,320 L (1,141 gal) (Hertzel 1996). This is compared to the current mass balance leak detection capabilities of approximately 21,000 to $31,300 \mathrm{~L}(5,570$ to 8,270 gal).

Sluicing retrieval, or other low-water volume technology, for low-risk, assumed-sound tanks will mitigate the potential leak volume (and thus, the consequences) by retrieving in a structured sequence within each tank, applying the appropriate leak detection systems (currently mass balance technique), and by having detailed operational procedures and responses available to respond to any leak detected. The consequences of any leak which should occur can be controlled in this manner to assure that the risks to the worker, the public, 
and the environment are minimized.

These historical leak rates provide the only current means to estimate the bounds and validity of leak rate models and their assumptions. Historically, the average leak rate which can be expected to occur during the retrieval of a SST is approximately $0.11 \mathrm{~L} / \mathrm{min}$ $(0.03 \mathrm{gal} / \mathrm{min})$. Such estimates will be reassessed and confirmed during development of the SST Retrieval Program work plan.

\subsubsection{Availability of Waste for Feed Delivery. A principal requirement of the SST retrieval system is to provide feed for the privatized waste immobilization facilities. To verify that the proposed alternative strategy would support this requirement, an analysis was conducted of the tank and waste form information presented in Appendix A to determine if sufficient inventories of wastes were available in sound tanks to support a dual track approach that focused on sound tanks.}

The analysis indicates the sound tanks contain $84,300 \mathrm{~m}^{3}(22,184 \mathrm{kgal})$ in inventories of HLW and LLW or 64 percent of the total waste volume. Furthermore, the Tri-Party Agreement retrieval sequence and schedule allows sludge and saltcake waste retrieval from sound tanks through 2014 (see Figure 4-3). The retrieval program has the option to retrieve wastes earlier than 2014, if necessary, from tanks assumed to have leaked. The sequence decisions will be developed as part of the retrieval program plan.

The analysis also indicates that the contribution to waste feed delivery requirements from tanks with historical leakage in excess of $38 \mathrm{~m}^{3}(10,000$ gal) is not required until the year 2016. The analysis concluded that sufficient inventory of wastes are contained in sound tanks to support the feasibility of the alternative strategy to satisfy waste feed delivery requirements.

\subsubsection{Availability of Low Risk Technology. There are several technologies that are} potentially applicable to support the retrieval function and limit the risks of retrieval leakage. Appendix $\mathrm{E}$ of this MAR more fully discusses the information available and reviewed on retrieval technologies and supporting systems. For the purpose of demonstrating feasibility, two water-based technologies are briefly discussed as a demonstration of an available path forward. The actual selection of technologies for retrieval application will be developed in the retrieval work plan.

Sprinklers for saltcake, in this concept a rotating, low hydraulic head (e.g., $5 \mathrm{gal} / \mathrm{min}$ ) water distributor and saltwell pump are installed in the SST. The distributor introduces water at a controlled rate which would percolate through and dissolve the saltcake. The saltwell pump would remove the saltcake brine. This concept is similar to systems being tested at Savannah River (Wiersma 1996). The principal advantage of this concept is in its simplicity, low flow rates which facilitate metering, and use of existing saltwell pumping systems and infrastructure. The effectiveness of this technology has not been tested for Hanford applications. 
Confined Sluicing for Saltcake or Sludge, in this concept a hydraulic, pneumatic, or cable actuated positioning device is used to deploy the confined sluicer and control its placement. A sluicing fluid, either water or recycled supernate is supplied under pressure to the sluicer. The sluicing fluid is projected onto the waste surface through nozzles within the sluicer shroud. Dissolved and mobilized wastes are removed through a suction line in the center of the sluicer. This system minimizes water head by immediately removing the working and retrieved fluids.

\subsubsection{Public Benefit and Risk Reduction. There are multiple analyses that could be} performed to assess the benefits to the public and the environment by proceeding with SST waste retrieval under the alternative strategy. The programmatic downside to proceeding is the potential increase in costs due to multiple retrieval campaigns to meet evolving requirements. To assess the benefits against the programmatic risks, the mission analysis reviewed the opportunity to reduce the in-tank inventory of ${ }^{99} \mathrm{Tc}$, a long-lived, mobile radioisotope. The data presented in Appendix A indicate that ${ }^{99} \mathrm{Tc}$ is primarily contained in the saltcake. The analysis demonstrates that a substantial in-tank reduction of ${ }^{99} \mathrm{Tc}$ inventory is available for retrieval under the alternative strategy (see Figure 4-4).

Figure 4-4. Single-Shell Tank Technetium Inventory.

Reduction in SST Waste Inventory with Time

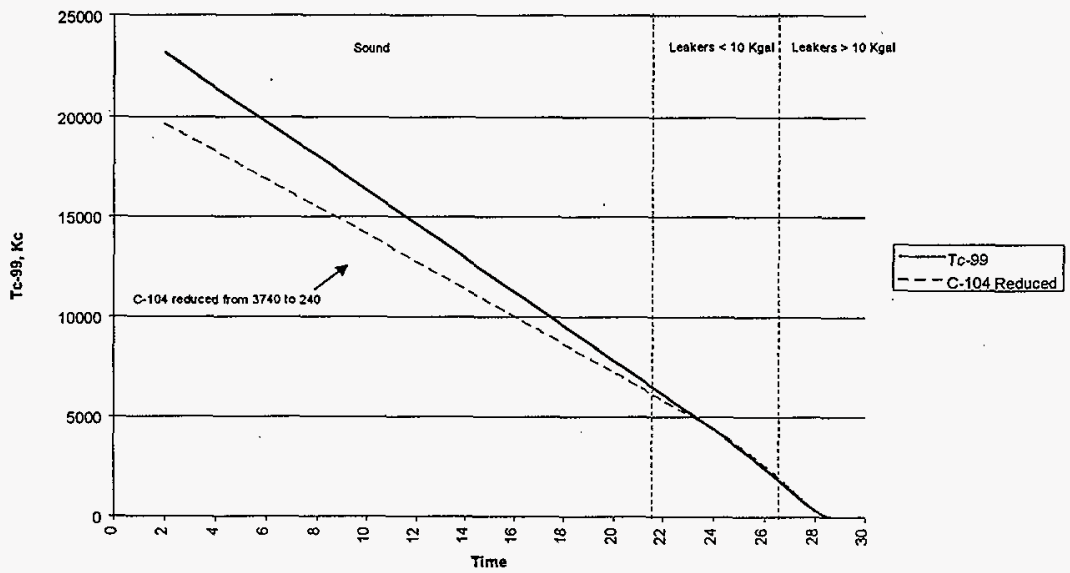

Note: The Best-Basis Inventory (BBI) currently indicates tank 241-C-104 to be an order of magnitude higher in technetium content than other SSTs. The graph depicts 241-C-104 levels at current BBI report and also as adjusted to expected level. 
Technetium-99 is a radioactive fission product. The production of in-tank inventories of this isotope was selected as an indicator of public benefit and risk reduction because it is mobile, has a long half-life, and is present in the SST wastes in large quantities. This isotope is considered one of the principal contributors to long term risk to public health and the environment from wastes at Hanford (DOE 1996 and Kincaid et al. 1998).

The data indicate that approximately 75 percent of the ${ }^{99} \mathrm{Tc}$ inventory is contained in sound tanks. Furthermore, technetium is predominantly contained in saltcake, which may be retrievable using simple water-based technologies discussed previously. A reduction of ${ }^{99} \mathrm{Tc}$ in the SST system would significantly reduce the public and environmental risk posed by potential future tank leaks.

\subsubsection{Enabling Assumptions}

The principal programmatic assumptions used in the development of the SST Retrieval strategy are listed below. These assumptions are consistent with the program goals and objectives, and provide sufficient latitude for the development of a risk-based, cost effective program plan. The assumptions listed here are the program level assumptions. The program assumptions will be augmented by detailed project planning assumptions which will be developed as part of the Multi-Year.Work Plan.

- The Closure EIS process will develop risk-based, retrieval performance criteria for waste removal from SSTs.

- The deployment of multiple technologies and the planning of multiple retrieval campaigns is an acceptable approach for SST waste retrieval.

- Proceeding with initial SST waste retrieval campaigns prior to finalization of retrieval performance criteria through the Closure NEPA process will not impose substantial cost increases to the retrieval program.

- Hydraulic retrieval is an accepted technology for removing SST wastes from tanks which are considered sound.

- Low hydraulic head retrieval is the only viable technology in the near-term for removing large quantities of waste from tanks.

- Tanks that are considered sound may leak during hydraulic retrieval. The leak rate assumptions will be specified in the program plan.

- All retrieval operations will employ a leak detection, monitoring and mitigation system. The system's design features will be commensurate with the level of risk to the public and environment posed by the planned retrieval. 
- Tanks that have been classified as tanks assumed to have leaked would be expected to leak during hydraulic retrieval. Leak rate assumptions will be specified in the program plan.

- There are sufficient volumes of HLW and LLW in sound SSTs to support waste feed delivery requirements and comply with retrieval schedules of the Tri-Party Agreement to allow time for development and demonstration of suitable, low-risk retrieval technologies for tanks that have leaked.

\subsubsection{Life-Cycle Description}

The SST Retrieval Program life cycle is the system that retrieves the SST waste by specific target dates, delivers retrieved wastes to the feed delivery system, and turns retrieved tanks over to the Closure Program for closure of the SST Tank Farms. The SST Retrieval Program is an integral part of the SST Program life-cycle which encompasses the SST Closure Program and the technology development efforts of the HTI and the contaminant leak impact investigations of the Vadose Zone Program. SST Retrieval Program is defined as the systems developed to complete SST retrieval by 2018 to satisfy Tri-Party Agreement milestones.

The life-cycle system is developed in the Program Level 0.5 logic, depicted in Figure 4-6. The logic identifies the programmatic activities to support the dual track strategy as discussed.

The first row of this figure is the path forward for SST retrieval if the retrieval performance and closure criteria were developed. Pending development of this criteria, the decision point provides alternate paths to proceed with retrieval and develop the required closure information through the Closure NEPA process. The second row of depicted activities is the development of the retrieval and closure criteria that correlates to Track 2 activities. The activities that will occur. in this row are technology development and deployment, and NEPA process for Closure of SST Tank Farms, namely the risk assessment, and RCRA closure plan that will follow the NEPA process. The third row of depicted activities is the initial retrieval activities supporting the cleanup progress and correlates to Track 1 activities. These activities are saltcake retrieval, waste feed delivery, and limits of retrieval technology assessments.

In the near-term, retrieval of SSTs must be performed to minimize the potential for tank waste leakage pending confirmation of tank integrity information and deployment of costeffective mitigating retrieval technologies. This will be accomplished by selecting sound tanks that are at low risk of leakage, employing retrieval technologies that minimize the amount of excess standing water in the tank, and employing leak detection strategies that signal an early liquid loss from the tank (Track 1). As experience is gained and technologies are demonstrated; the deployed retrieval systems will be optimized on economy and risk mitigation. 


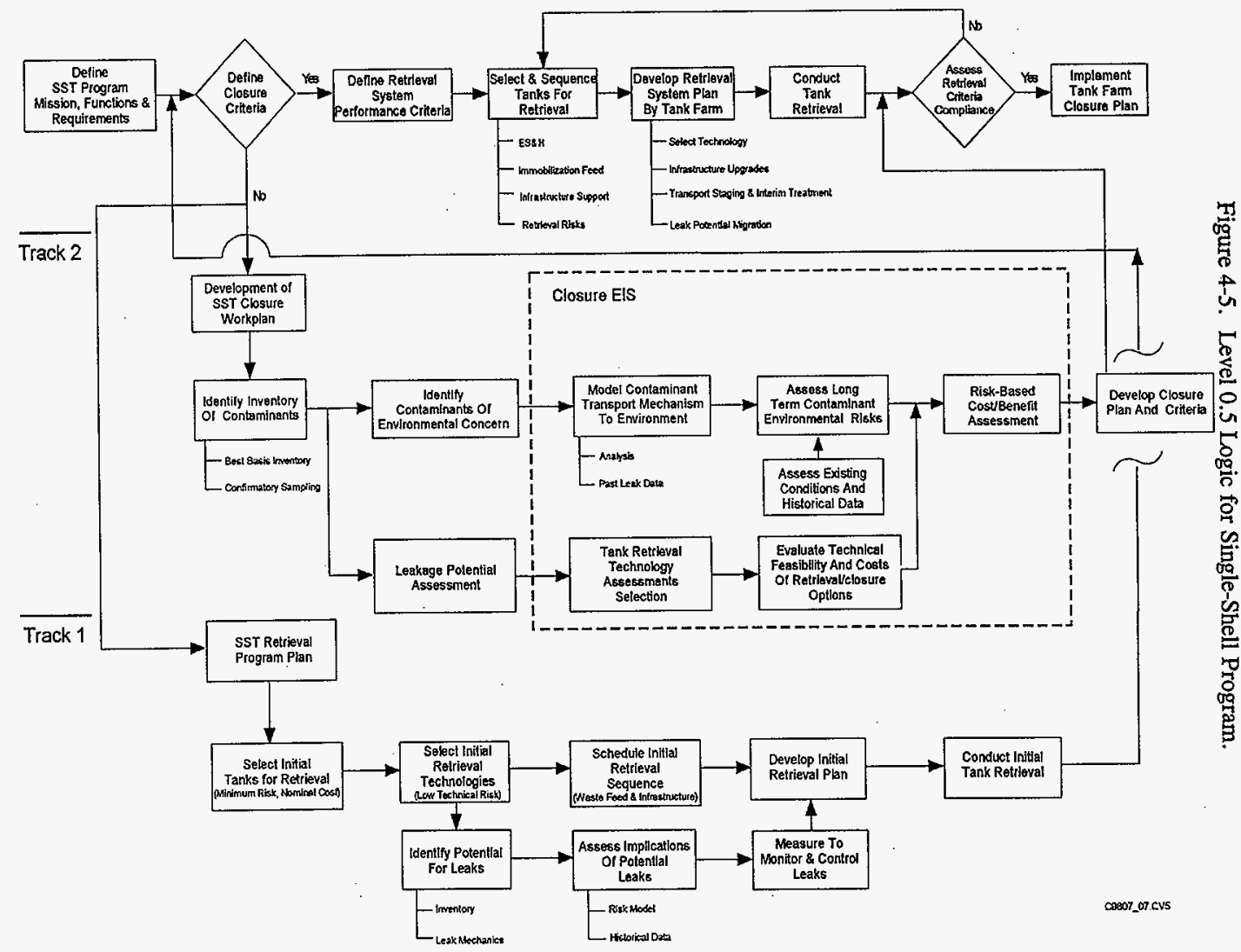


The Track 1 retrieval efforts will incorporate activities to mitigate the potential to leak tank waste. Information on public risk potential will be utilized as input for selection of retrieval technologies for demonstration and deployment during retrieval processes.

In the longer-term, when the program has gained substantial retrieval experience, the focus will turn to retrieving waste from suspect SSTs and tanks with a known history of significant tank waste leaks. Retrieval of these tanks will be planned to minimize retrieval risk to the public and environmental, and that appropriate technologies will be deployed with enough lead time to assure continuum between retrieving waste from low risk of leakage tanks and retrieving waste from higher risk of leakage tanks.

\subsubsection{Program Integration}

The SST Retrieval Program along with the Vadose Zone Program, the Closure Program and the HTI comprise the SST Program within TWRS Tank Waste Retrieval. The organizational relationship of these programs is depicted in Figure 4-6.

Figure 4-6. Single-Shell Tank Program Organization.

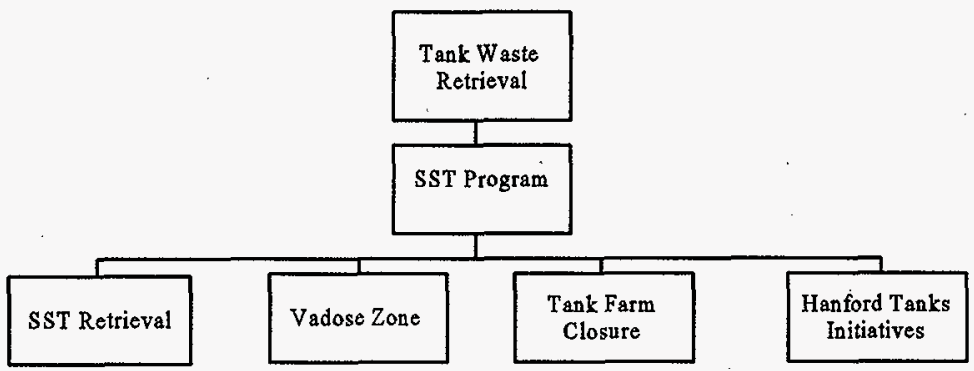

The SST Program has two products: (1) waste feed to DSTs for ultimate immobilization and disposal, and (2) closed tank farms per the requirements of the Closure EIS and ROD. It is the principal responsibility of the SST Retrieval Program to retrieve and transfer waste feed for ultimate immobilization.

Each of the SST program components has a unique scope and definable products to support the overall program mission. Below is a brief discussion of the program scopes and product integration. 
SST Retrieval Program was established as the organizational element for the retrieval of bulk wastes from tanks and the transfer of those retrieved wastes to the DSTs for ultimate immobilization and disposal. To support this mission, information not available elsewhere in TWRS, regarding advanced retrieval technologies, retrieval performance criteria, and impacts of potential retrieval leaks on the environment and public needed to be developed.

Additionally, the disposition of the retrieved tanks required an integrated approach with retrieval and the informational development efforts to attain closure in accordance with the requirements identified during the Closure NEPA process.

To support these programmatic needs, the HTI and the Vadose Zone Program were chartered to develop the technology, information, and assessment tools to execute the retrieval mission. To respond to the need for an integrated closure effort, the Closure Program was chartered to develop the closure systems, closure criteria and execute required closure activities on the retrieved tanks and tank farms.

Integration of these efforts with the SST Retrieval Program is being managed from a "top-down" programmatic approach. This MAR has identified the programmatic informational needs for the SST Retrieval and the SST Closure Programs. These programmatic needs form the basis of the mission statements for HTI and the Vadose Zone Programs, as well as identified interfaces between the retrieval and closure activities. Integration of the program planning requirements is accomplished through the specification of the program information needs and interacting functions in the top level program planning documents.

Integration of program work activities is accomplished through the Multi-Year Work Planning process and the development of integrated baseline program logics and planning schedules. Figure 4-7 depicts the principal SST Programs and internal program level product and information integration. 
HNF-2944

Revision 0

Figure 4-7. Single-Shell Tank Program Integration.

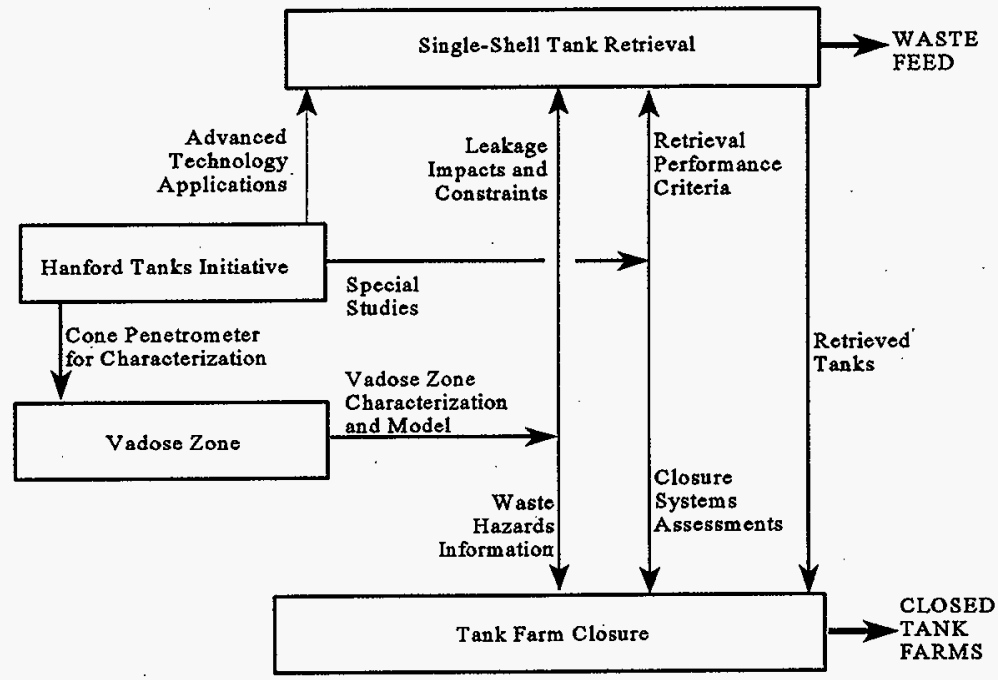




\subsection{COMPARISON BETWEEN ALTERNATIVE STRATEGY AND CURRENT BASELINE}

As presented earlier, there are four principal issues facing the SST Retrieval Program. They are as follows:

- Retrieval endpoints and requirements for closure have not been established.

- Impact of leaks on public health and the environment are not known.

- Waste feed to planned immobilization facilities demands a nine fold increase in SST waste retrieval rate after 2012. The ability of system logistics to support this retrieval rate is questionable without changes to basic assumptions for retrieval technology and infrastructure.

- DST system space availability and required infrastructure upgrades constrains SST waste retrieval rate though 2012.

Without changes to existing assumptions and constraints, completion of SST retrieval to meet the 2018 Tri-Party Agreement milestone is not likely.

- The start dates and processing rates for waste immobilization facilities are a major influence on (1) DST space availability for retrieved SST waste, and (2) the required rates of SST waste retrieval to support desired waste processing rates.

The alternative strategy addresses some of these issues and constraints. Remaining issues and constraints discussed below, must be addressed in development of an SST Retrieval Program Plan.

\subsubsection{Retrieval Endpoints and Requirements Determinations}

The retrieval endpoints and retrieval requirements are established by the NEPA-EIS process. Although these criteria are not determined by the SST Retrieval Program, activities within the SST Retrieval, Vadose Zone, Closure and HTI programs significantly contribute to the EIS process.

The alternative strategy allows SST retrieval to begin in parallel to development of endpoints. By selecting tanks with contents sure to require retrieval (i.e., high mobile contaminant content), the program is intended to spend government funds where there is likely to be the greatest benefit. The alternative strategy also identifies specific information needed to support regulatory decisions on endpoints and requirements. 


\begin{tabular}{|l|l|}
\hline \multicolumn{1}{|c|}{ Current Baseline } & \multicolumn{1}{c|}{ Alternative Approach } \\
\hline $\begin{array}{c}\text { The current baseline for retrieval is } \\
-\quad \begin{array}{l}\text { Milestone driven, and } \\
\text { benefit assessment for retrieval. }\end{array}\end{array}$ & $\begin{array}{r}\text { The two track approach is designed to } \\
\text { Develop data and information for } \\
\text { endpoint and performance targets, and } \\
\text { Support risk-based, cost benefit } \\
\text { decision-making. }\end{array}$ \\
$\begin{array}{l}\text { The SST program elements are integrated for } \\
\text { cost-effective production and use of retrieval } \\
\text { data. }\end{array}$ \\
\hline $\begin{array}{l}\text { The current baseline assumes } \\
\text { technology. }\end{array}$ & $\begin{array}{l}\text { Acknowledges multiple entries may be } \\
\text { required. }\end{array}$ \\
$\begin{array}{l}\text { The assumptions have not been } \\
\text { demonstrated. }\end{array}$ & $\begin{array}{l}\text { Initial retrievals remove bulk wastes and } \\
\text { reduce risks of future leaks. }\end{array}$ \\
\hline
\end{tabular}

\subsubsection{Impact of Leaks on Public Health and the Environment}

The 1997 TWRSO\&UP (Kirkbride et al. 1997) results focused on balancing the available DST space and meeting the Tri-Party Agreement milestones for initiating retrieval. This resulted in selecting tanks with low volumes of waste in the early years when available DST space is at a premium. The baseline sequence did not preference sound versus tanks that are assumed to have leaked. The alternative strategy focuses on sound SSTs and removing early-on as much waste as there is free space in the DSTs. By focusing on sound tanks with significant inventory, the risk to the soil surrounding the tank from retrieval or future tank leaks is reduced. 


\begin{tabular}{|c|c|c|}
\hline \multicolumn{2}{|c|}{ Current Baseline } & Alternative Approach \\
\hline $\begin{array}{l}\text { Baseline retrieval s } \\
\text { 2010: } \\
\text { 100 Series Tanks: } \\
200 \text { Series Tanks: }\end{array}$ & $\begin{array}{l}\text { lence for starts through } \\
23 \text { Total Starts } \\
15 \text { are tanks that are } \\
\text { assumed to have } \\
\text { leaked } \\
6 \text { have leaked > } \\
10 \mathrm{kgal} \\
6 \text { Total Starts } \\
4 \text { are tanks that are } \\
\text { assumed to have } \\
\text { leaked }\end{array}$ & $\begin{array}{l}\text { Focus on sound tanks and accept potential of } \\
\text { multiple campaigns to comply with Tri-Party } \\
\text { Agreement retrieval targets } \\
\text { - } 100 \text { Series Tanks, } 82 \text { Sound Tanks } \\
\text { - Sufficient Number to support Tri-Party } \\
\text { Agreement schedule to } 2014 \\
\text { - } 200 \text { Series Tanks are low volume, low } \\
\text { priority }\end{array}$ \\
\hline $\begin{array}{l}\text { Baseline Waste Vo } \\
\text { - Initiate Retrie } \\
\text { of Total } \\
\text { - Complete Re } \\
25 \% \text { of Total } \\
\text { - Remove only }\end{array}$ & $\begin{array}{l}\text { I Removed thru } 2012 \text { : } \\
\text { I Tanks or } 29 \% \\
\% \text { of Waste Inventory }\end{array}$ & $\begin{array}{l}\text { Select sound tanks with large inventories of } \\
\text { mobile contaminants, and readily retrievable } \\
\text { wastes } \\
\begin{array}{l}22,000 \mathrm{kgal} \text { of waste in sound tanks } \\
(64 \% \text { of SST waste inventory) } \\
\text { - } \quad 16,000 \mathrm{kgal} \text { of saltcake in sound tanks } \\
\quad(50 \% \text { of SST waste inventory or } 70 \% \\
\text { of SST saltcake inventory) } \\
\text { - Bulk of }{ }^{99} \mathrm{Tc}(75 \%) \text { in saltcake }\end{array}\end{array}$ \\
\hline
\end{tabular}

\subsubsection{Feasibility of Retrieval Logistics}

The logistical demands for retrieving waste are very complicated under the current baseline: About 10 tank retrievals have to be operating at one time, and in the later years 15 retrievals have to be performed per year. The immobilization facility will have to produce about $180 \mathrm{MT}$ of glass per day to accommodate the production surge required in the later years to meet the Tri-Party Agreement SST retrieval milestones.

The current baseline retrieval rates are as follows:

- Retrieval between $2003-2012$ : $14 \%$ of total waste volume

$4,900 \mathrm{kgal}$

$500 \mathrm{kgal}$ per year 
HNF-2944

Revision 0

- Retrieval between $2013-2020$ : $86 \%$ of total waste volume $30,000 \mathrm{kgal}$

$4,300 \mathrm{kgal}$ per year

The baseline requires a nine-fold increase in waste retrieval rates after 2012 and requires 10 SSTs to be sluiced simultaneously and carry out 15 retrievals per year. A management assessment of this retrieval schedule recommended that planning for more than five tanks to be retrieved simultaneously is unrealistic and not recommended (Payne et al. 1998).

Recent information for the privatized waste immobilization facilities indicate a later start of waste processing (2004 - 2006) compared with the current plan (2002), and less total waste processed during Phase 1 (10 percent by volume versus 13 percent). Phase 1 would also end later (2016 versus 2011) under the most recent scenario. Under these assumptions, completion of SST retrieval to meet the 2018 Tri-Party Agreement milestone is unrealistic. Payne et al. (1998) recommended an acceleration of the Phase 2 start date by three years (see Figure 4-8 and Table 4-1). This early start of Phase 2 processing would provide DST space for earlier retrieval of SSTs and relax the logistical challenges for completing SST retrieval. This thought process can be applied to the more recent processing plans.

Table 4-1. Comparison of Tank Waste Remediation System Planning Baseline and Example Mission Improvements Case. (Payne 1998)

\begin{tabular}{|l|c|c|}
\hline & TWRS planning baseline & $\begin{array}{c}\text { Example case-mission } \\
\text { improvements }\end{array}$ \\
\hline SST retrieval completion & 2020 & 2020 \\
\hline $\begin{array}{l}\text { Maximum retrieval systems } \\
\text { in operation }\end{array}$ & 11 & 5 \\
\hline $\begin{array}{l}\text { Maximum Phase 2 melter } \\
\text { rate (MT glass/day for each } \\
\text { private contractor) }\end{array}$ & $86 \mathrm{MT} /$ day* & $40 \mathrm{MT} /$ day \\
\hline $\begin{array}{l}\text { Waste processed by 2011 } \\
\text { (MT sodium) }\end{array}$ & $10,000 \mathrm{MT}$ & $21,000 \mathrm{MT}$ \\
\hline
\end{tabular}

*Average rate over Phase 2 is approximately $60 \mathrm{MT}$ per contractor per day, but 86 MT per contractor per day will be required early in Phase 2.

$\mathrm{MT}=$ metric ton

SST $=$ single-shell tank

TWRS $=$ Tank Waste Remediation System . 


\section{Revision 0}

Figure 4-8. Example Mission Improvements--Low-Activity Waste Processing.

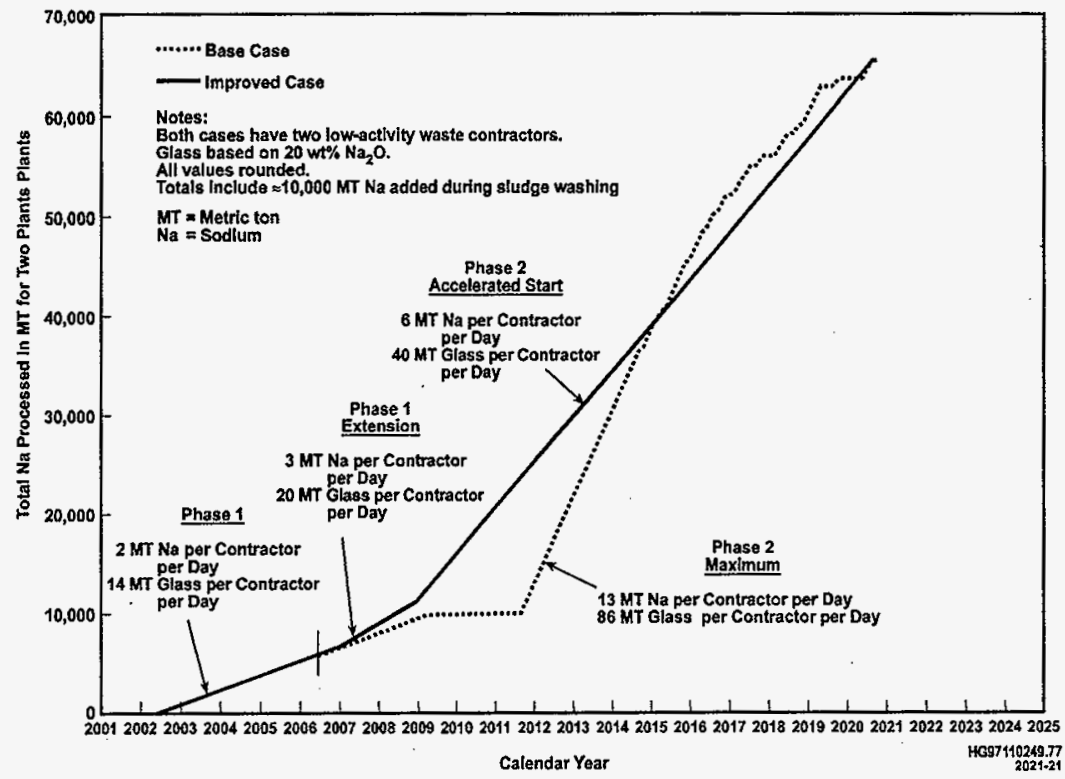

The alternative strategy begins with bulk retrieval from sound tanks with significant inventories of wastes. This strategy focuses on the waste of greatest concern first. Reducing retrieval logistical constraints is a significant issue for development of optimal SST retrieval plans.

\subsubsection{Double-Shell Tank System Space Availability}

The primary internal constraint to the current baseline performance is the availability of DST system space, under the following:

- The current DST system configuration (28 tanks available)

- DST space management assumptions (emergency capacity and waste segregation)

- Assumptions regarding the immobilization facility operations schedule and production capacity (start dates and average processing rates). 
To increase DST free space, Payne et al. (1998) suggested accelerating immobilization facility production rates in the years immediately following the immobilization demonstration of envelopes A, B, and C waste feed. The envelope demonstration rate is about $13 \mathrm{MT}$ per day per contractor. The alternative strategy encourages the immobilization rate to move to 40 MT per day. This will free up DST tank space. This freed up space lets the SST retrieval progress at a reasonably slower pace for a longer time.

Solutions for the DST space constraint on SST retrieval rates is a significant issue to be addressed in development of SST retrieval plans.

\subsection{STAKEHOLDER VALUES}

The SST Retrieval Program has a consistent and common goal with Stakeholders: the reduction of risks to workers, the public, and the environment. The alternative strategy emphasizes this goal by placing priority on retrieving sound tanks with significant inventories of mobile contaminants, and the use of low-volume, water-based retrieval technologies.

The two track approach allows the SST Retrieval Program to make progress on many of the concerns raised by Stakeholders while information needed to finalize the key closure decisions is developed within SST Retrieval and other TWRS program components.

The alternative strategy was evaluated against the values of the Hanford Stakeholders presented in the Hanford Tank Waste Task Force Final Report (HTWTF 1993), and Public Values Related to Decisions in the Tank Waste Remediation System Program (Dirks and VonWinterfeldt 1994). The focus on removal of wastes with mobile contaminants, initial retrieval from sound tanks, building of experience in sound tanks with technology applicable to tanks that have leaked, and emphasis on low-head hydraulic retrieval technologies responds directly to the Stakeholder values, as discussed below:

- Protect the public, and worker health and safety: By focusing on retrieval of bulk wastes from sound tanks, the proposed approach reduces the potential for both retrieval leaks and future tank leaks. Expertise gained in technology performance and retrieval of the various waste forms will enhance safety and performance when applied to tanks that have leaked.

- Protect the Columbia River: With an emphasis to remove waste with mobile contaminant inventories, this places priority on retrieval of contaminants that pose the most significant threat to the Columbia River and future site use. 
- Cleanup to the level necessary to enable future use options to occur: The twotrack approach is designed to make progress with cleanup while decisions on future land use and closure issues are resolved through the NEPA process. The strategy recognizes that subsequent retrievals may be necessary to meet closure requirements and does not preclude any option from consideration.

- Capture economic development opportunities locally: Not specifically addressed by this strategy.

- Protect the rights of the Tribal Nations: The strategy promotes retrieval from sound tanks first, and builds a performance track record for selecting retrieval and leak detection systems prior to retrieval. This approach allows progress while minimizing the risk of further contamination prior to final land use determinations.

- Ensure compliance: This MAR is part of a systematic approach that incorporates regulatory requirements into the development and implementation of SST Retrieval plans.

- Reduce cost: An evaluation of the baseline indicated that current constraints, requirements, and assumptions promoted a retrieval sequence which targeted low volume tanks, many of which were also assumed to have leaked. This tends to increase the cost per unit of waste retrieved and increase the risk to the program from potential retrieval leaks. The strategy proposed focuses on bulk waste retrieval and development of a performance track record for retrieval systems prior to retrieval of tanks that have leaked. This approach reduces the unit cost of retrieval and reduces the programmatic risk when applying these technologies to tanks that have leaked.

- Use a systems approach: This mission analysis report is the first product of the systems approach to be used for remediating SSTs.

- Do not rely on unproven technologies, and use technology innovations as they become available: The alternative strategy focuses on available technologies. TWRS has focused on commercial technologies and demonstration of those technologies for Hanford applications. The TWRS program actively promotes technology assessment through the Tanks Focus Area and participation with other DOE sites in technology evaluations.

- Make progress with the cleanup activities: This value is the primary theme of the alternative strategy. The approach promotes cleanup progress while developing the information necessary to make the key decisions on closure requirements. The strategy accepts the programmatic risk associated with the potential for multiple retrievals while proceeding with bulk waste retrieval under Track 1 . 
- Allocate funds to high priority items: Track 1 of this strategy promotes bulk retrieval of wastes. Track 2 of the strategy emphasizes development of key information to assess risk and define the retrieval and closure requirements. This approach allows the program to allocate funds on priority items and optimize performance when requirements are defined through the NEPA process.

\subsection{SUMMARY}

A number of uncertainties and constraints remain with the alternative strategy for SST retrieval. Compared with the current SST retrieval baseline, however, the alternative strategy allows external constraints (e.g., retrieval endpoints) to be addressed in parallel to the retrieval of waste from the first SSTs. This allows real progress to be made on TWRS cleanup using reasonable assumptions that will result in a safe and cost effective program.

Internal uncertainties and constraints (e.g., waste characteristics for retrieval and processing, achievable retrieval rates, optimal infrastructure configuration for SST retrieval, DST space availability, waste processing schedules and rates) can be identified separate from external uncertainties and constraints. These internal issues will be addressed as part of the systematic development of SST retrieval plans.

The key technical information needed for developing and executing the Alterative Strategy is discussed in Appendix E. 
HNF-2944

Revision 0

This page intentionally left blank. 
HNF-2944

Revision 0

\subsection{REFERENCES}

Acree, C. D. 1998, Tank Waste Remediation System Mission Analysis Report, HNF-SD-WM-MAR-008, Rev. 3, Lockheed Martin Hanford Corporation, Richland, Washington.

Anantatmula, R. P., E. B.Schwenk, M. J. Danielson, 1994, Characterization of Corrosion Behavior of the Carbon Steel Liner in Hanford Site Single-Shell Tank, WHC-EP-0722, Rev. 0, Westinghouse Hanford Company, Richland, Washington.

Bloom, G. R., and Q. H. Nguyen, 1995, Characterization Data Needs for Development, Design, and Operations of Retrieval Equipment Developed Through the Data Quality Objective Process, WHC-SD-WM-DQO-008, Revision 0, Westinghouse Hanford Company, Richland, Washington.

Boston, H. L., 1998, Guidance for Tank Waste Remediation System Single-Shell Tank Retrieval Logic and Scoping Analysis, letter to A. M. Umek, Correspondence LMHC-9761599A R3 (February 19), Lockheed Martin Hanford Corporation, Richland, Washington.

Carothers, K. G., et al., 1998, Tank 241-C-106 Waste Retrieval Sluicing System Process Control Plan, HNF-SD-WM-PCP-013, Revision 0, Lockheed Martin Hanford Corporation, Richland, Washington.

Dirks, L. L., and D. VonWinterfeldt, 1994, Public Value Related to Decisions in Tank Waste Remediation System Program, PNL-10107, Pacific Northwest Laboratory, Richland, Washington.

DOE and Ecology, 1996, Tank Waste Remediation System, Hanford Site, Richland, Washington, Final Environmental Impact Statement, DOE/EIS-0189, U.S. Department of Energy, Richland Operations Office, Richland, Washington, and Washington State Department of Ecology, Olympia, Washington.

DOE, 1997a, Hanford Site Environmental Management Specification, DOE/RL-97-55, Revision 0, (December 8), U.S. Department of Energy, Richland Operations Office, Richland, Washington.

DOE, 1997b, TWRS Waste Disposal Division Planning Guidance, (June 13) U.S. Department of Energy, Richland Operations Office, Richland, Washington.

DOE, 1997c, Record of Decision for the Tank Waste Remediation System, Hanford Site, Richland, Washington, 62 FR 8693, 2/26/97, U.S. Department of Energy, Richland Operations Office, Richland, Washington. 
HNF-2944

Revision 0

DOE, 1998, Supplement Analysis for the Tank Waste Remediation System, DOE/EIS-0189-SA2, (May 1998), U.S. Department of Energy, Richland Operations Office, Richland, Washington.

Ecology, EPA, and DOE, 1996, Hanford Federal Facility Agreement and Consent Order, as amended, Washington State Department of Ecology, U.S. Environmental Protection Agency, and U.S. Department of Energy, Olympia, Washington.

Fowler, K. D., 1995, Data Quality Objectives for Tank Farms Waste Compatibility Program, WHC-SD-WM-DQO-001, Revision 1, Westinghouse Hanford Company, Richland, Washington.

Freeman, D. V., 1998, Tank Waste Remediation System Program Plan, HNF-1883, Rev. 0, prepared by Lockheed Martin Hanford Corporation for Fluor Daniel Hanford, Inc., Richland, Washington.

GJO, 1997, Hanford Tank Farms Vadose Zone, BY Tank Farm Report, GJO-96-2-TAR, GHO-HAN-6, U.S. Department of Energy, Albuquerque Operations Office, Grand Juntion Office, Grand Junction, Colorado.

GJO, 1998a, Hanford Tank Farms Vadose Zone, BX Tank Farm Report, GJO-98-40-TAR, GHO-HAN-19, U.S. Department of Energy, Albuquerque Operations Office, Grand Juntion Office, Grand Junction, Colorado.

GJO, 1998b, Hanford Tank Farms Vadose Zone, TY Tank Farm Report, GJO-98-30-TAR, GHO-HAN-16, U.S. Department of Energy, Albuquerque Operations Office, Grand Juntion Office, Grand Junction, Colorado.

Hanlon, B. M., 1998, Waste Tank Summary Report for Month Ending March 31, 1998, HNF-EP-0182-120, May 1998, prepared by Lockheed Martin Hanford Corporation for Fluor Daniel Hanford, Inc., Richland, Washington.

Hendel, B. J., and P. S. Schaus, 1998, Mission Analysis Report for the Hanford Tanks Initiative, HNF-SD-HTI-MAR-001, Rev. 1, Lockheed Martin Hanford Corporation, Richland, Washington.

Hertzel, J. S., 1996, Operational Tank Leak Detection and Minimization During Retrieval, WHC-SD-ES-377, Rev. 0, Westinghouse Hanford Company, Richland, Washington.

HFSWG, 1992, The Future for Hanford: Uses and Cleanup, the Final Report of the Hanford Future Site Uses Working Group, Hanford Future Site Uses Working Group, Westinghouse Hanford Company, Richland, Washington 
HNF-2944

Revision 0

Hodges, F. N., 1998, Results of Phase I Groundwater Quality Assessment for Single-Shell Tank Waste Management Areas $T$ and TX-TY at the Hanford Site, PNNL-11809, Pacific Northwest National Laboratory, Richland, Washington.

Hodgson, K. M., and M. D. LeClair, 1996, Work Plan for Defining a Standard Inventory Estimate for Wastes Stored in Hanford Site Underground Tanks, WHC-SD-WM-WP-311, Revision 1, Lockheed Martin Hanford Corporation, Richland, Washington.

HTWTF, 1993, Finai Report: Hanford Tank Waste Task Force, Hanford Tank Waste Tank Force, Washington State Department of Ecology, U.S. Department of Energy, and U.S. Environmental Protection Agency, Richland, Washington.

Isaacson, R. E., and K. A. Gasper, 1981, A Scientific Basis for Establishing Dry Well Monitoring Frequencies, RHO-ST-34, Rockwell Hanford Operations, Richland, Washington.

Johnson, M. G., 1995, Technical Basis for Leak Detection Surveillance of Waste Storage Tanks, WHC-SD-WM-TI-573, Rev. 1, Westinghouse Hanford Company, Richland, Washington.

Johnson, V. G., and C. J. Chou, 1998, Results of Phase I Groundwater Quality Assessment for Single-Shell Tank Waste Management Areas S-SX at the Hanford Site, PNNL-11810, Pacific Northwest National Laboratory, Richland, Washington.

Kincaid, C. T., et al., 1998, Composite Analysis for Low-Level Waste Disposal in the 200 Area Plateau of the Hanford Site, PNNL-11800, Richland, Washington

Kirkbride, R. A., G. K. Allen, P. J. Certa, A. F. Manuel, R. M. Orme, L. W. Shelton, E. J. Slaathaug, R. S. Wittman, and G. T. MacLean and D. L. Penwell (SESC), 1997, Tank Waste Remediation System Operation and Vtilization Plan, HNF-SD-WM-SP-012, Rev. 0, Vol. I and II, Numatec Hanford Corporation, Richland, Washington.

Kupfer, M. J., A. L. Boldt, B. A. Higley, K. M. Hodgson, L. W. Shelton, and R. A. Watrous (LMHC), S. L. Lambert, and D. E. Place (SESC), R. M. Orme (NHC), G. L. Borsheim, (Borsheim Associates), N. G. Colton (PNNL), M. D. LeClair (SAIC), R. T. Winward (Meier Associates), and W. W. Schulz W'2 S Corporation), 1997, Standard Inventories of Chemicals and Radionuclides in Hanford Site Tank Wastes, HNF-SD-WM-TI-740, Rev. 0A, Lockheed Martin Hanford Corporation, Richland, Washington.

Narbutovskih, S. M., 1998, Results of Phase I Groundwater Quality Assessment for SingleShell Tank Waste Management Areas B-BX-BY at the Hanford Site, PNNL-11826, Pacific Northwest National Laboratory, Richland, Washington. 
HNF-2944

Revision 0

National Environmental Policy Act of 1969, Public Law, 42 USC 4321 et seq.

Payne, M. A., J. O. Honeyman, J. G. Kristofzski, W. T. Thompson, P. J. Certa (NHC), Management Assessment of Tank Waste Remediation System Contractor Readiness to Proceed with Phase $1 B$ Privatization, HNF-2021, Lockheed Martin Hanford Corporation, Richland, Washington.

Peck, L. G., 1998, Tank Waste Remediation System Systems Engineering Management Plan, HNF-SD-WM-SEMP-002, Rev. 1, prepared by Lockheed Martin Hanford Corporation for Fluor Daniel Hanford, Inc., Richland, Washington.

Resource Conservation and Recovery Act of 1976, as amended, 42 USC 6901 et seq.

Rodenhizer, D. G., 1987, Hanford Waste Tank Sluicing History, SD-WM-TI-302, Westinghouse Hanford Company, Richland, Washington.

Ross, W. E. (LMHC), R. D. Smith and D. T. Vladimiroff (FDNW), D. V. Freeman (MACTEC), J. R. Biggs, V. C. Boyles, J. O. Honeyman, J. R. Kriskovich, K. Parnell, R. P. Raven, D. J. Saueressig, S. E. Seeman, and W. R. Swita (LMHC), 1998, SingleShell Tank Interim Stabilization Project Plan, HNF-2358, Rev. 1, Lockheed Martin Hanford Corporation, Richland, Washington.

Taylor, W. J., 1997a, Contract Number DE-AC06-96RL13200 - Waste Disposal Division (WDD) Multi-Year Work Plan (MYWP) Guidance for FY 1998, 97-WDD-128, letter to H. J. Hatch, Fluor Daniel Hanford (August 6), U.S. Department of Energy, Richland Operations Office, Richland, Washington.

Taylor, W. J., 1997b, Guidance for the Tank Waste Remediation System of Single-Shell Tanks (SST) Retrieval Logic and Scoping Analysis, letter to H. J. Hatch, Fluor Daniel Hanford, Correspondence \#9761599 A (December 11), U.S. Department of Energy, Richland Operations Office, Richland, Washington.

Vann, J. M., E. R. Hamm, and R. D. Crisp, 1998, Tank Waste Remediation System Configuration Management Plan, HNF-1900, Rev. 0, prepared by Lockheed Martin Hanford Corporation for Fluor Daniel Hanford, Inc., Richland, Washington.

WAC 173-303, "Dangerous Waste Regulations," Washington Administrative Code, as amended.

WHC, 1996a, Tank Waste Remediation System Administration Manual, WHC-IP-0842, Volume IV--Engineering, Section 3.1, Mission Analysis, Westinghouse Hanford Company, Richland, Washington. 
WHC, 1996b, Initial Single-Shell Tank Retrieval System Mission Analysis Report, WHC-SD-WM-MAR-009, Rev. 0, Westinghouse Hanford Company, Richland, Washington.

Wiersma, B. J., 1996, An Investigation of Density Driven Salt Dissolution Techniques, WSRC-TR-96-0160, Westinghouse Savannah River Company, Aiken, Georgia.

Zimmerman, B. D., 1998, Tank Waste Remediation System Risk Management Plan, HNF-SD-WM-PMP-018, Rev. 2, prepared by Lockheed Martin Hanford Corporation for Fluor Daniel Hanford, Inc., Richland, Washington. 
HNF-2944

Revision 0

This page intentionally left blank. 
HNF-2944

Revision 0

\section{APPENDIX A}

\section{TANK STATUS FOR WASTE FORM AND INTEGRITY}


HNF-2944

Revision 0

This page intentionally left blank. 
HNF-2944

Revision 0

\section{APPENDIX A}

\section{TANK STATUS FOR WASTE FORM AND INTEGRITY}

Figure A-1, "Single-Shell Tank Waste Contents and Leak Status," was created in an attempt to capture a visualization of the single-shell tank (SST) system that would be helpful in analyzing the SST retrieval mission. The figure indicates the amount of sludge and saltcake in each tank, whether the tank is sound or an assumed leaker, if it needs to be saltwell pumped, and if it is on the watchlist. The data are summarized in a table on the figure that lists the quantities of waste in various groupings of tanks.

The data from which the figure is derived is contained in the monthly waste tank summary report (Hanlon 1998) which is periodically updated based on new information such as the best-basis inventory (Kupfer et al. 1997) and saltwell pumping progress. These data are also provided in EXCEL spreadsheet format in Table A-1 along with liquid waste volume data (Hanlon 1998), ${ }^{99} \mathrm{Tc}$ activity (Kupfer et al. 1997), the calculated average tank waste depth, and an indicator of the stress corrosion cracking potential - CF (Anantamula 1994). [Note: The $\mathrm{CF}$ values are in the process of being revised based on the best-basis inventory (Kupfer et al. 1997).] In addition, each tank has been arbitrarily categorized as a saltcake (SC - greater than 90 percent saltcake), sludge (SL - greater than 95 percent sludge), or mixed ( $M$ - saltcake and sludge) tank for grouping purposes.

The figure has proven very useful as a tool for gaining insight into the SST retrieval mission and as a communication device. The spreadsheet has also proven useful with its ability to provide special sorts on tank and waste attributes.

\section{REFERENCES}

Anantatmula, R. P., E. B.Schwenk, M. J. Danieison, 1994, Characterization of Corrosion Behavior of the Carbon. Steel Liner in Hanford Site Single-Shell Tank, WHC-EP-0722, Rev. 0, Westinghouse Hanford Company, Richland, Washington.

Hanlon, B. M., 1998, Waste Tank Summary Report for Month Ending March 31, 1998, HNF-EP-0182-120, May 1998, prepared by Lockheed Martin Hanford Corporation for Fluor Daniel Hanford, Inc., Richland, Washington.

Kupfer, M. J., A. L. Boldt, B. A. Higley, K. M. Hodgson, L. W. Shelton, and R. A. Watrous (LMHC), S. L. Lambert, and D. E. Place (SESC), R. M. Orme (NHC), G. L. Borsheim, (Borsheim Associates), N. G. Colton (PNNL), M. D. LeClair (SAIC), R. T. Winward (Meier Associates), and W. W. Schulz (W² S Corporation), 1997, Standard Inventories of Chemicals and Radionuclides in Hanford Sire Tank Wastes, HNF-SD-WM-TI-740, Rev. 0A, Lockheed Martin Hanford Corporation, Richland, Washington. 
HNF-2944

Revision 0

This page intentionally left blank. 


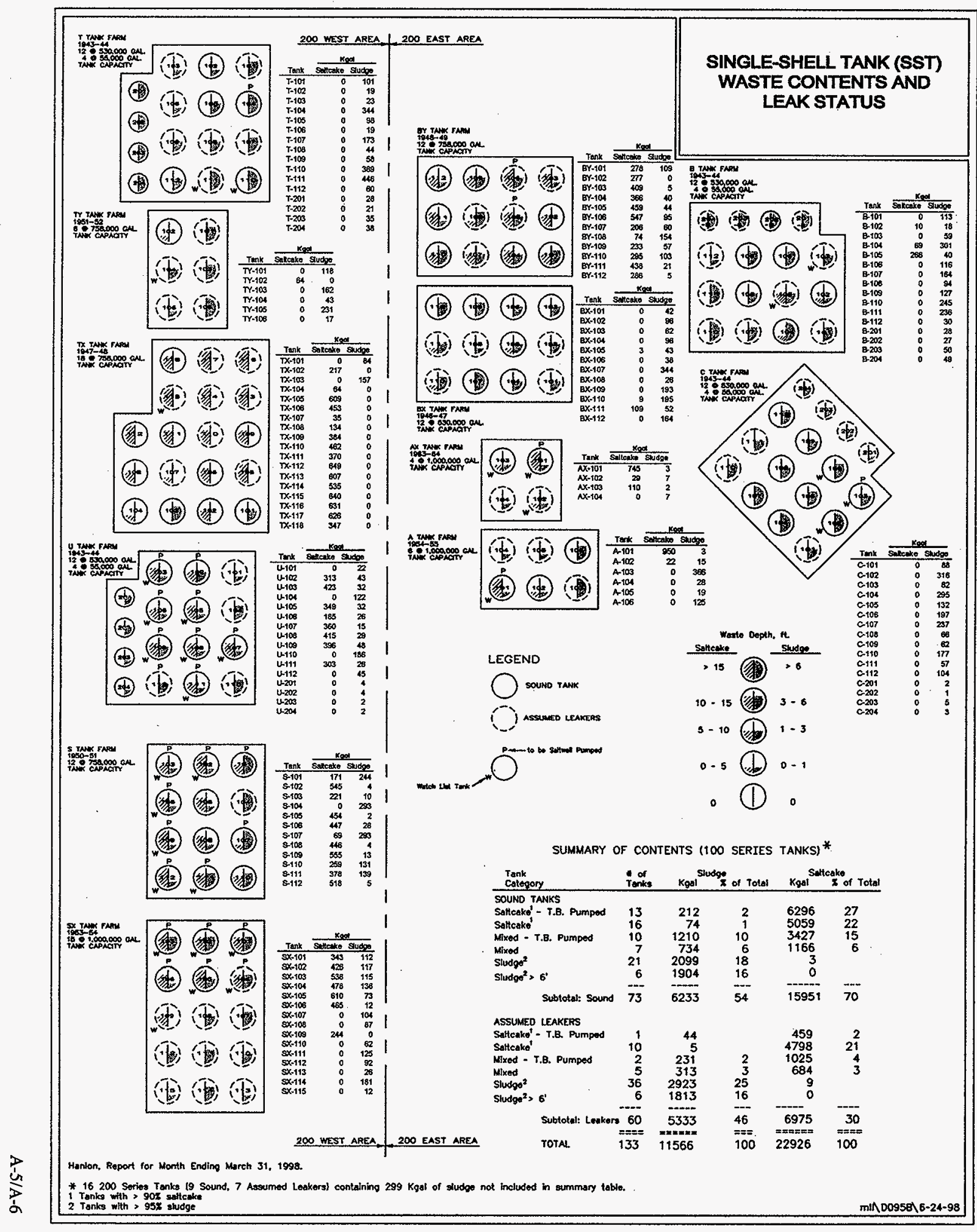

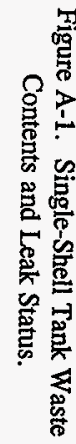

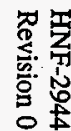


Table A-1. Single-Shell Tank Data. (6 Sheets)

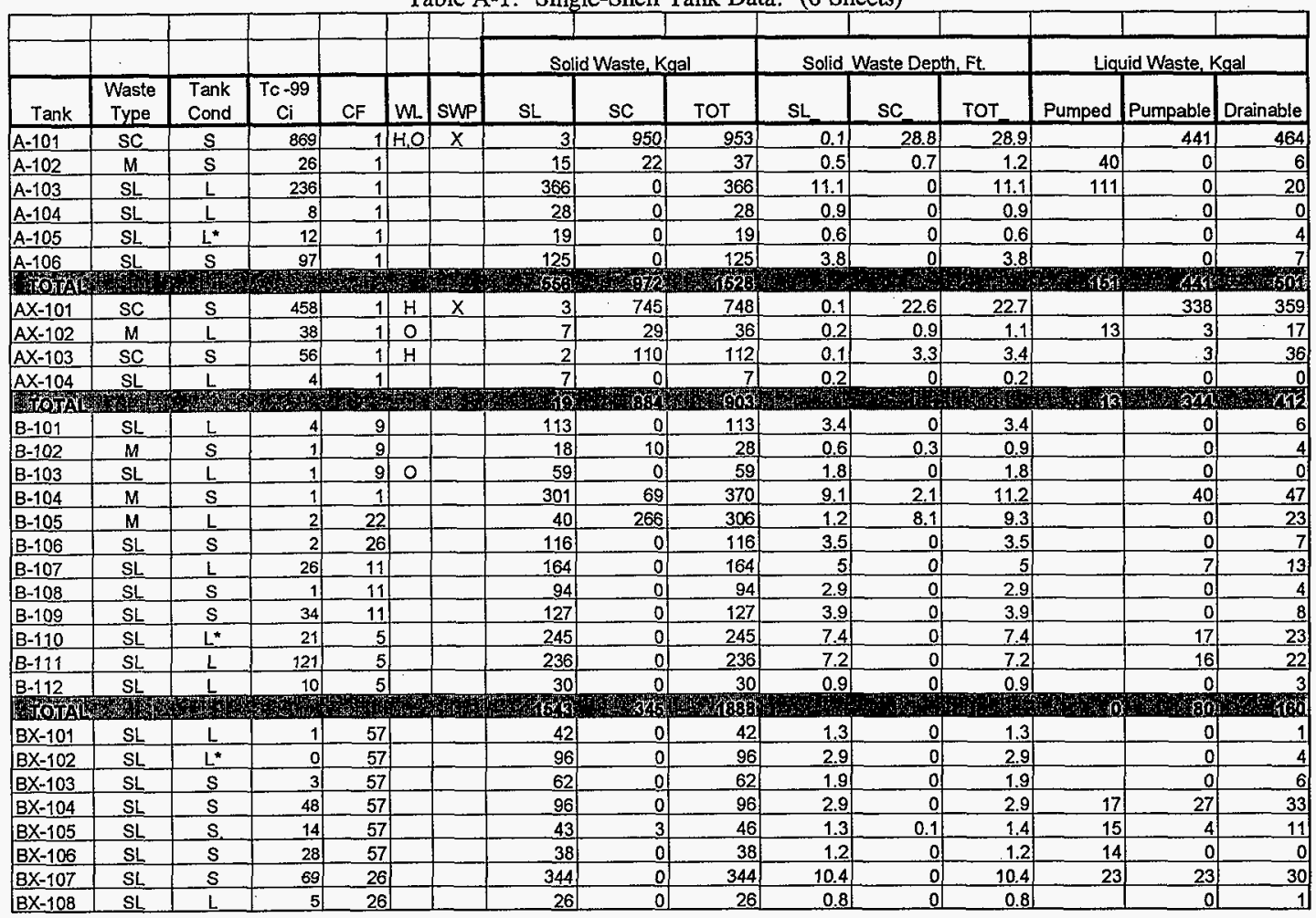


Table A-1. Single-Shell Tank Data. (6 Sheets)

\begin{tabular}{|c|c|c|c|c|c|c|c|c|c|c|c|c|c|c|c|}
\hline & & & & & & & & & & & & & & & \\
\hline & & & & & & & \multicolumn{3}{|c|}{ Solid Waste, Kgal } & \multicolumn{3}{|c|}{ Solid Waste Depth, Ft. } & \multicolumn{3}{|c|}{ Liquid Waste, Kgal } \\
\hline Tank & $\begin{array}{c}\text { Waste } \\
\text { Type }\end{array}$ & $\begin{array}{l}\text { Tank } \\
\text { Cond }\end{array}$ & $\begin{array}{c}\text { Tc- }-99 \\
\mathrm{Ci}\end{array}$ & CF & $\mathrm{m}$. & SWP & St & sc & TOT & SL & sc. & TOT & Pumped & Pumpable & Drainable \\
\hline$A-101$ & SC & $s$ & 869 & 1 & $\mathrm{H,O}$ & $x$ & 3 & 950 & 953 & 0.1 & 28.8 & 28.9 & & 441 & 464 \\
\hline$A-102$ & $M$ & $s$ & 26 & 1 & & & 15 & 22 & 37 & 0.5 & 0.7 & 1.2 & 40 & a & 6 \\
\hline A-103 & $\mathrm{SL}$ & $L$ & 236 & 1 & & & 366 & 0 & 366 & 11.1 & 0 & 11.1 & 111. & 0 & 20 \\
\hline BX-109 & SL & $s$ & 1 & 1 & & & 193 & 0 & 193 & 5.9 & 0 & 5.9 & 8 & 8 & 13 \\
\hline BX-110 & SL & $L$ & 31 & 12 & & & 195 & 9 & 204 & 5.9 & 0.3 & 6.2 & 2 & 13 & 19 \\
\hline BX-111 & $M$ & L & 128 & 12. & & & 52 & 109 & 161 & 1.6 & 3.3 & 4.9 & 117 & 1 & 3 \\
\hline $\mathrm{BX}-112$ & SL & S & 2 & 11 & & & 164 & 0 & 164 & 5 & 0 & 5 & 4 & 2 & 8 \\
\hline BY-101 & $M$ & s & 251 & 46 & & & 109 & 278 & 387 & 3.3 & 8.4 & 11.7 & 36 & o. & 5 \\
\hline$B Y-102$ & sc & $\frac{s}{S}$ & 231 & 68 & & & 0 & 277 & 277 & 0 & 8.4 & 8.4 & 159 & 0 & 11 \\
\hline BY-103 & SC & $L$ & 280 & 46 & & & 5 & 409 & 414 & 0.1 & 12.4 & 12.5 & 96 & 32 & 38 \\
\hline BY-104 & SC & s & 128 & 46 & & & 40 & 366 & 406 & 1.2 & 11,1 & 12.3 & 330 & 0 & 18 \\
\hline BY-105 & sC & L & 243 & 46 & & $x$ & 44 & 459 & 503 & 1.3 & 13.9 & 15.2 & & 216 & 228 \\
\hline BY-106 & $M$ & $\mathrm{~L}$ & 391 & 46 & & $x$ & 95 & 547 & 642 & 2.9 & 16.6 & 19.5 & 64 & 163. & 200 \\
\hline BY-107 & $M$ & $L^{\star}$ & 108 & 46 & & & 60 & 206 & 266 & 1.8 & 6.2 & 8 & 56 & 0 & 25 \\
\hline BY-108 & $M$ & L & 47 & 46 & & & 154 & 74 & 228 & 4.7 & 2.2 & 6.9 & 28 & 0 & 9 \\
\hline BY-109 & $M$ & $s$ & 278 & 68 & & & 57 & 233 & 290 & 1.7 & 7.1 & 8.8 & 157 & 20 & 37 \\
\hline BY- 110 & $M$ & $\mathrm{~s}$ & 151 & 46 & & & 103 & 295 & 398 & 3.1 & 8.9 & 12 & 213 & 0 & 9 \\
\hline $8 Y-111$ & SC & $s$ & 310 & 46 & & & 21 & 438 & 459 & 0.6 & 13.3 & 13.9 & 313 & 0 & 0 \\
\hline BY-112 & SC & $s$ & 203 & 46 & & & 5 & 286 & 291 & 0.1 & 8.7 & 8.8 & 116 & 0 & 8 \\
\hline Ox/ & & & & & & & & $69+4$ & 2 & & & & & & \\
\hline C 101 & SL & $L^{*}$ & 0 & 57 & & & 88 & 0 & 88 & 2.7 & o) & 2.7 & & of & 3 \\
\hline C. 102 & $\mathrm{SL}$ & $S$ & 1 & 25 & 0 & & 316 & 0 & 316 & 9.6 & of & 9.6 & 47 & 17 & 30 \\
\hline$c-103$ & $\mathrm{SL}$ & $s$ & 213 & 25 & 0 & $x$ & 62 & a & 62 & 1.9 & of & 1.9 & & 133 & 135 \\
\hline$c_{-104}$ & SL & $s$ & 3,740 & 1 & & & 295 & 0 & 295 & 8.9 & of & 8.9 & & 5 & 11 \\
\hline C-105 & SL. & $s$ & 98 & 25 & & & 132 & D & 132 & 4 & o) & 4 & & 9 & 32 \\
\hline$c_{-106}$ & SL & $s$ & 221 & 25 & $\mathrm{HH}$ & & 197 & 0 & 197 & 6 & 0 & 6 & & 52 & 62 \\
\hline$c-107$ & $S L$ & $s$ & 105 & 1 & & & 237 & 0 & 237 & 7.2 & of & 7.2 & 41 & 15 & 24 \\
\hline C-108 & $\mathrm{SL}$ & $\mathrm{s}$ & 0 & 36 & & & 66 & 0 & 66 & 2 & 0 & 2 & & o & 0 \\
\hline C-109 & SL & $s$ & 1 & 36 & & & 62 & 0 . & 62 & 1.9 & 0 & 1.9 & & 0 & 4 \\
\hline$c-110$ & $S L$ & $L$ & 34 & 26 & & & 177 & D) & 177 & 5.4 & of & 5.4 & 16 & 15) & 29 \\
\hline$c_{-111}$ & $S L$ & L & 0 & 36 & & & 57 & 0 & 57 & 1.7 & 0 & 1.7 & & 0 & 0 \\
\hline$C-112$ & $\mathrm{SL}$ & $S$ & 80 & 36 & & & 104 & 0 & 104 & 3.2 & 0 & 3.2 & & 26 & 32 \\
\hline & -43 & 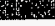 & & & & & & & & & & & & bat & 862 \\
\hline S-101 & $M$ & $s$ & 229 & 14 & & $x$ & 244 & 171 & 415 & 7.4 & 5.2 & 12.6 & & 127 & 138 \\
\hline S-102 & SC & $s$ & 244 & 14 & $\mathrm{H}, \mathrm{O}$ & $x$ & 4 & 545 & 549 & 0.1 & 16.5 & 16.6 & & 239 & 262 \\
\hline
\end{tabular}


Table A-1. Single-Shell Tank Data. (6 Sheets)

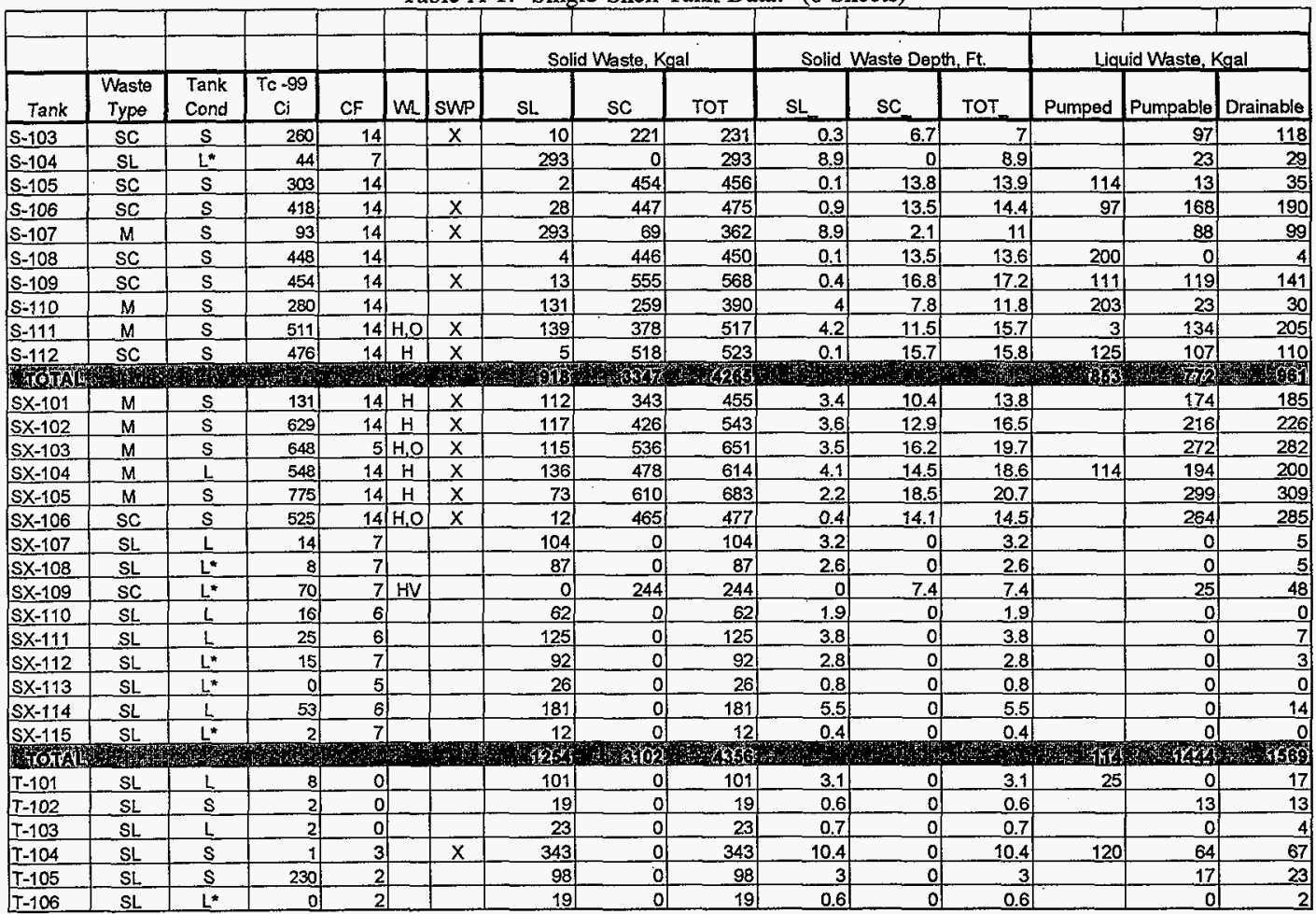


Table A-1. Single-Shell Tank Data. (6 Sheets)

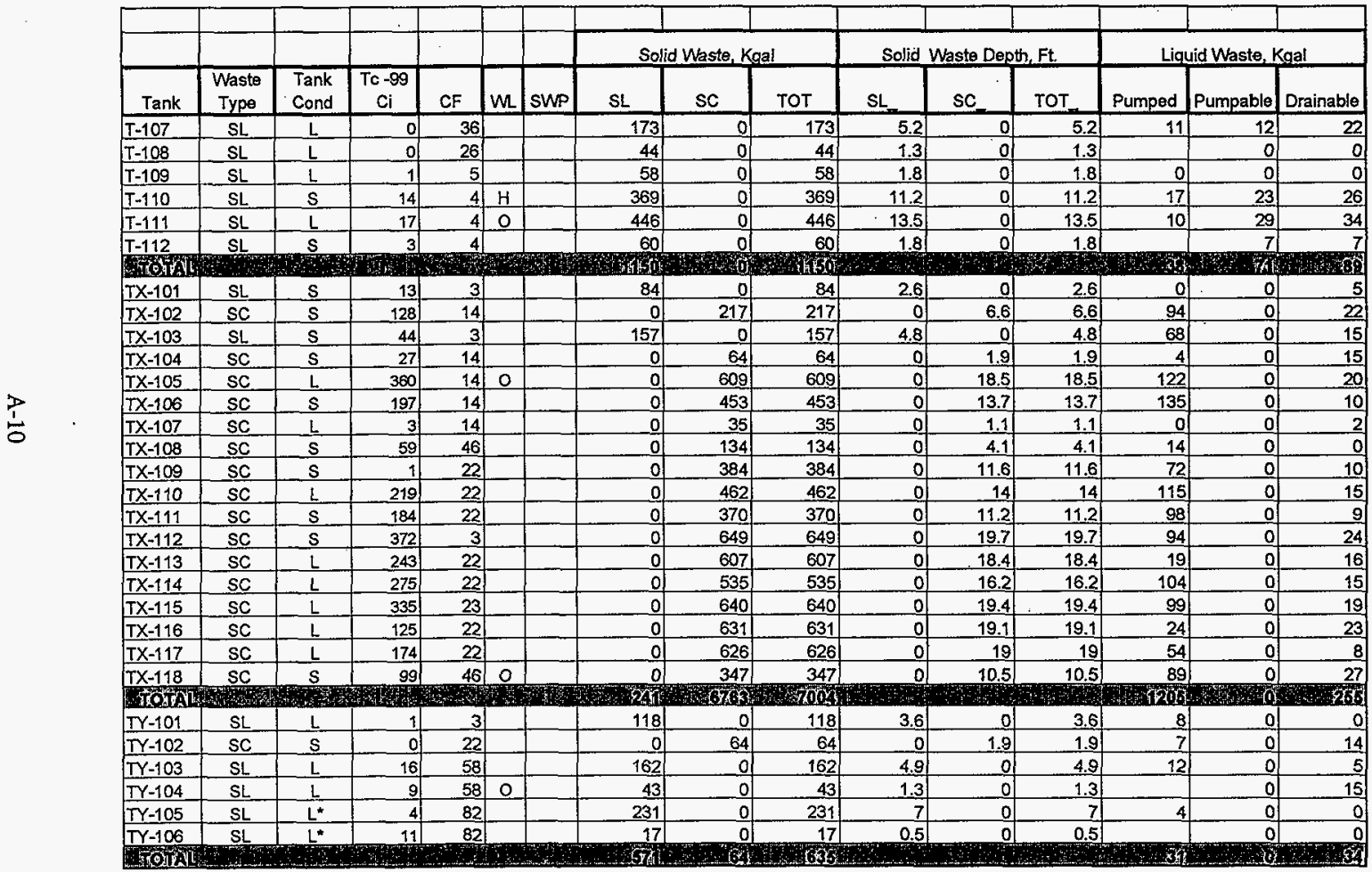


Table A-1. Single-Shell Tank Data. (6 Sheets)

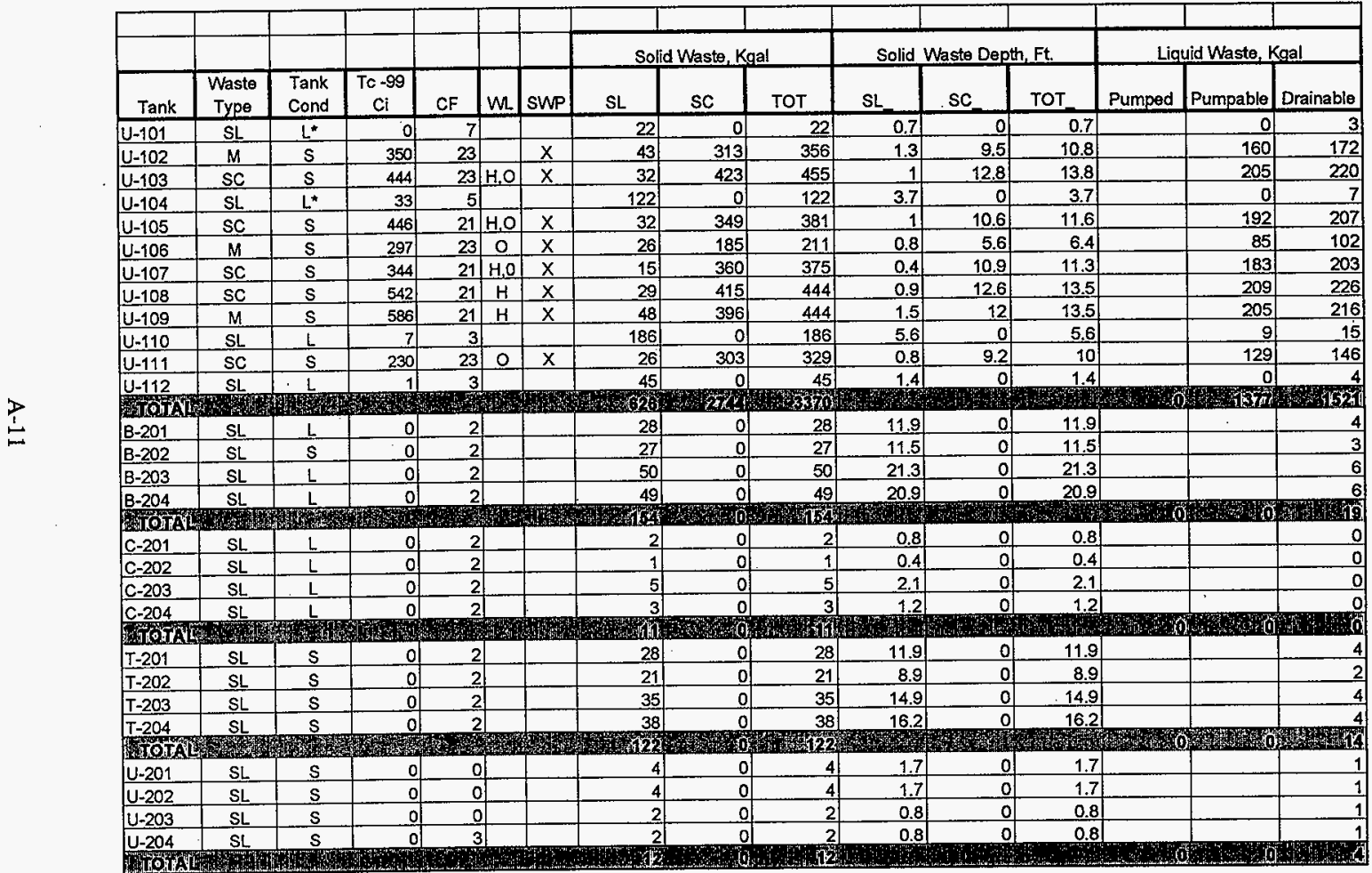


Table A-1. Single-Shell Tank Data. (6 Sheets)

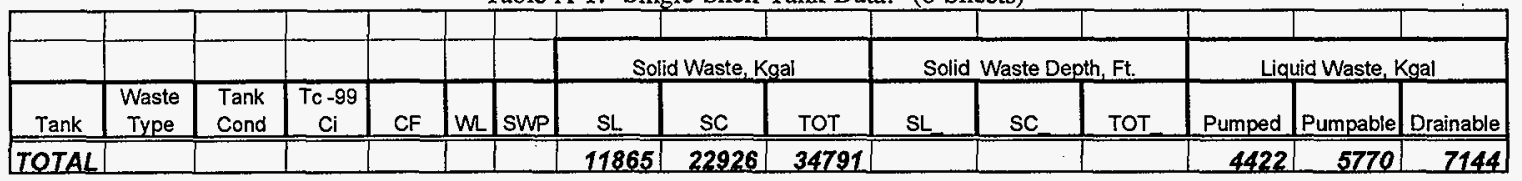


HNF-2944

Revision 0

\section{APPENDIX B}

\section{SOURCES OF SINGLE-SHELL TANK WASTES}


HNF-2944

Revision 0

This page intentionally left blank. 
HNF-2944

Revision 0

APPENDIX B

SOURCES OF SINGLE-SHELL TANK WASTES

(Note: The following information was abridged from an historical tank contents document [Brevick 1997])

\subsection{INTRODUCTION}

The purpose of this historical characterization document is to present the synthesized summaries of the historical records concerning the physical, radiological, and chemical composition of mixed wastes stored in underground single-shell tanks and the physical conditions of these tanks. This section provides information on processes that produced the waste in the underground waste storage tanks.

The SST are located on the U.S. Department of Energy Hanford Site, approximately 25 miles northwest of Richland, Washington. The historical data was used to assist in characterizing the waste in the tanks in conjunction with sampling and analyzing the tank wastes. Los Alamos National Laboratory (LANL) developed computer models that used the historical data to attempt to characterize the wastes and to generate estimates of each tank's inventory. A historical review of the tanks may reveal anomalies or unusual contents that could be critical to retrieval activities.

This data was developed by reviewing the operating plant process histories, waste transfer data, and available physical and chemical data from numerous resources. These resources were generated by numerous contractors from 1945 to the present.

\subsection{WASTE GENERATING PLANTS AND PROCESSES}

Brief descriptions and histories of the plants and processes that generated waste now contained in the SSTs and DSTs are presented in alphabetical order. Typically, the name of the plant and the process are synonymous." The dates and events described in the following brief histories. Although not all of the processes listed below contributed waste directly to all tanks, the waste they generated could have been transferred indirectly tank-to-tank.

\section{A Plant (PUREX)}

The Plutonium-Uranium Extraction (PUREX) plant (i.e., A Plant) began operating in January 1956 (Gerber 1993b). "The PUREX process is an advanced solvent extraction process 
that uses a tributyl phosphate in kerosene solvent for recovering uranium and plutonium from nitric acid solutions of irradiated uranium. Nitric acid is used instead of metallic nitrates to promote the extraction of uranium and plutonium from aqueous phase to an organic phase." (Wilson and Reep 1991, p. B-4). Two campaigns of the Thorex process were conducted in 1966 and 1971 (Jungfleisch 1984). The Thorex process recovered ${ }^{233} \mathrm{U}$ from thorium irradiated in the Hanford Site reactors (Wilson and Reep 1991). PUREX reprocessed aluminum-clad fuel elements and zirconium alloy clad fuel elements, and provided plutonium for research reactor development, safety programs, and defense. Also, PUREX recovered slightly enriched uranium to be recycled as fuel in reactors generating electricity and plutonium (Rockwell 1985). PUREX was put on standby in 1972 (Gerber 1993b).

The PUREX plant was restarted in November 1983, but was shut down in December 1988. The plant was shut down due to the lack of steam pressure needed to operate the support backup safety equipment. There was a brief stabilization run in early 1990 . In October 1990, PUREX was placed on standby by Secretary of Energy James Watkins. DOE issued the final closure order in December 1992 (Gerber 1993c).

\section{B Plant}

B Plant used the bismuth phosphate process at first, and later changed its processing capabilities to strontium and cesium fractionation. The bismuth phosphate process "separated plutonium from uranium and the bulk of fission products in irradiated fuel by co-precipitation with bismuth phosphate from a uranium nitrate solution. The plutonium was then separated from fission products by successive precipitation cycles using bismuth phosphate and lanthanum fluoride. The plutonium was isolated as a peroxide and, after dissolving in nitric acid, was concentrated as plutonium nitrate. The waste containing the uranium from which the plutonium had been separated, was made alkaline (neutralized) and stored in underground SSTs. Other acid waste (which included most of the fission products) generated by this process was neutralized and stored in other single-shell tanks" (Wilson and Reep 1991, p. B-3). "Some of the strontium and cesium fission products were removed (fractionated) from the waste and separately isolated to reduce the heat generation in the tanks. B Plant . . .was modified in 1968 to permit removal of these fission products by a combination of precipitation, solvent extraction, and ion-exchange steps. The residual acid waste from the processing was neutralized and stored in single-shell tanks" (Wilson and Reep 1991, pp. B-4 and $\mathrm{B}-5$ ).

B Plant began its first batch run on April 13, 1945 (Anderson, 1990), and was shutdown in 1952 (Gerber, 1993c). Shortly after the renovations to B Plant were completed in December 1955, the 4X Program was abandoned. The 4X Program "planned to utilize the capabilities of all four Hanford processing plants (B, T, REDOX, and PUREX)" (Gerber 1993c, p. 12), however, the large production and economic efficiency of the PUREX plant caused the 4X Program to be abandoned (Gerber 1993c). B Plant restarted in 1968 to recover cesium and strontium from stored liquid waste. Cesium and strontium recovery was completed in September 1983 and February 1985, respectively (Rockwell 1985). 
HNF-2944

Revision 0

\section{5-B (WESF)}

The Waste Encapsulation and Storage Facility (WESF) converted solutions of cesium and strontium nitrates recovered in B Plant to strontium fluoride and cesium chloride solids that are doubly encapsulated in metal (Ballinger and Hall, 1991). "Strontium and cesium capsules have been used in applications of fission byproducts for gamma and heat sources" (Wilson and Reep 1991, p. B-5).

WESF was constructed in 1974. The process optimization for cesium and strontium was completed in 1978 and 1981, respectively (Rockwell 1985). The cesium processing ended in 1983 and strontium encapsulation in 1985. The capsule return program started in 1988 and ended in 1995 (Gerber 1996).

\section{Plant (Strontium Semiworks)}

The Strontium or Hot Semiworks facility (i.e., C Plant) began operating in 1952 as a hot pilot plant for the REDOX process. In 1954, the plant was converted to a pilot plant for the PUREX process and continued operating until 1956 (Ballinger and Hall, 1991). "The process building (201-C) contains three hot cells equipped only for contact maintenance and is supported by an aqueous makeup and control building (271-C) and a solvent handling building (276-C). The facility also includes a fiberglass exhaust filter and a 200-ft stack" (PNL, 1991, Vol. 1, p. 3.6). In 1960 , the plant was reactivated as a pilot plant used to recover strontium 90, promethium 147, and cesium 144 from PUREX waste. The plant was shut down in 1967 and the building and the site have been decontaminated and decommissioned (PNL, 1991).

\section{S Plant (REDOX)}

The Reduction and Oxidation extraction (REDOX) plant (i.e., S Plant) began processing on January 9, 1952 (Anderson 1990). "The REDOX extraction process was a second-generation recovery process and the first process to recover both plutonium and uranium. It used a continuous solvent extraction process to extract plutonium and uranium from dissolved fuel into a methyl isobutyl ketone (hexone) solvent. The slightly acidic waste stream contained the fission products and large quantities of aluminum nitrate that were used to promote the extraction of plutonium and uranium. This waste was neutralized and stored in single-shell tanks. The volume of high-level waste from this process was much smaller than that from the bismuth phosphate process, "but larger than that from the PUREX process" (Wilson and Reep 1991, pp. B-3 and B-4). REDOX operated until 1967 (Rockwell 1985).

\section{T Plant}

T Plant was the first full-scale separations plant at the Hanford Site. T Plant used the bismuth phosphate process to separate plutonium from uranium and the bulk of fission 
products in irradiated fuel (B Plant used the same process). "The waste containing the uranium from which the plutonium had been separated was made alkaline (neutralized) and stored in underground single-shell tanks. Other acid waste (which included most of the fission products) generated by this process was neutralized and stored in other single-shell tanks" (Wilson and Reep 1991, p. B-3).

T Plant began operating in 1944 (Rockwell 1985) as a separations plant and continued until March 1956 (Gerber 1994a). T Plant's mission was changed in 1957 to the repair and high-level decontamination of equipment (Rockwell 1985). T Plant was converted to a "central decontamination facility for the site. As such, failed and contaminated equipment was assessed and either repaired or discarded there for over three decades" (Gerber 1994a, p. 1). Early decontamination operations used steam, sand, chemicals, and detergents. "Smaller equipment pieces were immersed in decontamination solutions in 'thimble tanks', and larger pieces were flushed with water, chemical solutions, sand-blasted, steam-blasted, high-pressure sprayed (using pressures up to $10,000 \mathrm{Ib} / \mathrm{in}^{2}$ ), and/or scrubbed with detergents.

During the initial years, a strong nitric acid flush (approximately 60 percent) usually began the decontamination process, followed by a caustic wash with sodium hydroxide combined with sodium phosphate, boric acid, versene, sodium dichromate, sodium tartrate, or sodium citrate. However, it was learned that versene and tartrate, in particular, adversely affected the ability of soil cribs to absorb the rinsate materials. High-pressure sprays often used 1,1,1 trichloroethane or perchloroethylene, and detergents generally were chloride-based. By the mid-1960s, commercially prepared and trademarked chemical mixtures had replaced most of the simpler chemicals used in the early years. Many commercial products were based on oxalic acid, phosphates, nitric acid-ferrous ammonium sulfate combinations, potassium permanganate, and sodium bisulfate, with some unknown additives" (Gerber 1994a, pp. 40-42). The facility was modified in 1978 to store pressurized water reactor (PWR) core II fuel assemblies (Rockwell 1985).

\section{U Plant}

U Plant (221-U) was built as one of three original bismuth phosphate process facilities, but it was not used for that purpose. U Plant was modified extensively and used for the uranium recovery process, operating from 1952 to 1958 . Uranium in waste from the bismuth phosphate process initially was stored in the SSTs. Later, the waste was sluiced, dissolved in nitric acid, and processed through a solvent extraction process using tributyl phosphate in kerosene to recover the uranium... The process was similar to that used later in the PUREX process except that plutonium was not recovered.

The acid waste from the uranium recovery process was made alkaline and returned to SSTs. The tributyl phosphate waste was treated with potassium ferrocyanide as a cesium and strontium scavenger. The recovery process resulted in an increase in nonradioactive salts and a small increase in waste volume (Wilson and Reep, 1991). 
HNF-2944

Revision 0

\section{Uranium Trioxide Plant}

The 224-U Building was converted to a uranium trioxide $\left(\mathrm{UO}_{3}\right)$ plant which began operating in 1952. The $\mathrm{UO}_{3}$ plant was capable of handling the uranyl nitrate hexahydrate (UNH) stream from REDOX, U Plant, and PUREX. "The basic $\mathrm{UO}_{3}$ process, calcining, consisted of concentrating and then heating liquid UNH until it converted to a stable, orange-yellow powder. The nitric acid in the UNH solution could be recovered in the same process. The $\mathrm{UO}_{3}$ powder was the base material needed for the manufacture of uranium hexafluoride $\left(\mathrm{UF}_{6}\right)$, the primary feed material for the United States' gaseous diffusion plants. Because the largest of these plants was located in Ohio and Tennessee, it was considered safer to ship the material across the country in powder rather than in liquid form" (Gerber 1993c, pp. 33-34).

The $\mathrm{UO}_{3}$ plant was shut down in 1972 , but restarted in 1984 . Since 1984 , there have been 17 campaigns at the plant averaging eight days each. Final deactivation was ordered for the plant in 1992. In April 1993, the $\mathrm{UO}_{3}$ Plant resumed operations to convert 200,000 gal of remaining $\mathrm{UNH}$ to $\mathrm{UO}_{3}$ powder. A final deactivation plan was written in the summer of 1993 (Gerber 1993c).

\section{Z Plant (Plutonium Finishing Plant)}

The Plutonium Finishing Plant (PFP) or Z Plant (previously called Plutonium Recovery and Finishing Operations) processed plutonium and prepared plutonium products. "Waste from this plant contained only minor amounts of fission products, but did contain low concentration of plutonium and other transuranic elements and was high in metallic nitrates.

Initially, this waste was discharged via cribs to soil columns, which absorbed the transuranic elements and retained them close to the point of discharge. Beginning in 1973, waste from PFP was stored with other waste in underground tanks" (Wilson and Reep 1991, p. B-4). "Three types of feed materials are processed at the PFP to produce plutonium metal. Feed material types are handled differently in different process lines. . . . Historically, the main feed for the PFP was purified plutonium nitrate solution that was produced elsewhere in a fuel reprocessing plant. This feed was charged directly to one of the main process lines, which was initially a glovebox line. The glovebox line was replaced by remote mechanical lines, which were upgraded over the years. In time, processes were added to handle rework and scrap plutonium. These processes were used to convert the rework and scrap materials into a purified plutonium nitrate solution that could be handled by the main process" (Duncan and Mayancsik 1993, pp. 2-1-2-2).

In July 1949, PFP began operations with a glove box line. The remote mechanical A line replaced the glove box line in May 1953. Installment of the Recuplex Facility at PFP was completed in April 1955. The remote mechanical C line was installed in July 1960. In September 1961, the 232-Z Building was installed with an incinerator and leaching equipment. In June 1964, the Plutonium Reclamation Facility (PRF) replaced the functions of the Recuplex Facility. Fabrication of plutonium metal nuclear weapon components ceased at the 
HNF-2944

Revision 0

PFP in December 1965. In April 1973, the 232-Z Incinerator was shut down and the remote mechanical C line was placed on standby. The PRF was placed on standby in February 1979, and the remote mechanical A line was shutdown in December 1979. In January 1984, the PRF was restarted for a series of campaigns. The remote mechanical $\mathrm{C}$ line was restarted in June 1985 for a series of campaigns. In September 1986, operations at PFP were halted for nine months. This partial listing of the process history in the Plutonium Finishing Plant is from D.R. Duncan et al. (1993).

\subsection{WASTE MANAGEMENT OPERATIONS}

This section describes the different methods used to concentrate waste in the 200 Areas. Evaporating, concentrating, and scavenging are all methods used to reduce liquid volumes or precipitate solids from supernate. Brief descriptions and histories of the operations are presented in alphabetical order.

\section{2-A Evaporator-Crystallizer}

"The program objective was to reduce the volume of tanked waste liquors through the boiloff of water. This was accomplished by boiling the liquor in an enclosed vessel at reduced pressure. The evaporation was carried out until a slurry containing about $30 \mathrm{wt} \%$ solids was formed. The slurry was returned to underground waste tanks for cooling, crystallization, and settling. The principal products of waste solidification have been large volumes of sodium nitrate salt cakes and waste liquors that are rich in sodium hydroxide and sodium aluminate." (Wilson and Reep 1991, p. B-5).

The 242-A Evaporator-Crystallizer began operating on March 18, 1977 (Anderson 1990) (see Figure 5). In 1981, the evaporator was shut down for ten months to tie AW Tank Farm into the process (Rockwell 1985). The evaporator was shut down in 1989 because of regulatory issues, but was restarted in 1994 after extensive modifications (Gerber 1996).

\section{2-B Evaporator}

"The first type of waste solidification facility, the 242-B and 242-T Concentrators, was originally used for concentration of bismuth phosphate process waste. In 1951, they began to concentrate cladding/first cycle waste. These concentrators were steam-heated pot evaporators operated outside the waste tanks and at atmospheric pressure. The liquors were partially boiled down and cycled to underground waste storage tanks" (Jungfleisch 1984, p. 1-5). This evaporator ran for approximately 4 years (Anderson 1990). 
HNF-2944

Revision 0

\section{2-S Evaporator-Crystallizer}

The 242-S Evaporator-Crystallizer was designed to boil off water from the waste in an enclosed vessel at reduced pressure, similar to the 242-A Evaporator-Crystallizer. "The evaporation was carried out until a slurry containing about $30 \mathrm{wt} \%$ solids was formed. The slurry was returned to underground waste tanks for cooling, crystallization, and settling. The principal products of waste solidification have been large volumes of sodium nitrate salt cakes and waste liquors that are rich in sodium hydroxide and sodium aluminate." (Wilson and Reep 1991, p. B-5). The evaporator began operating on November 1, 1973 (Anderson 1990) and was shut down in 1981 (Gerber 1996).

\section{2-T Evaporator}

The 242-T Evaporator, like the 242-B Evaporator, began operating in 1951 (Gerber 1992 ) to reclaim nonboiling waste storage capacity in existing tanks. The evaporator was shut down in the summer of 1955 and modified for tributyl phosphate scavenging (Godfrey 1965), although scavenging was never performed in this evaporator. The evaporator was restarted on December 3, 1965, and operated until April 15, 1976 (Anderson 1990).

\section{In-Tank Solidification}

The in-tank solidification systems immobilized high-level wastes, that were not self-boiling, by concentrating the waste directly inside of the tanks to form radionuclide-bearing salt cakes (Shefcik 1964). The first in-tank solidification unit (ITS-1) and the second in-tank solidification unit (ITS-2) operated in tanks in the BY Tank Farm (Caudill, 1965 and 1967). ". . .one used a hot air sparge (ITS-1) and the other used an immersed electrical heater (ITS-2). The ITS-1 operations were conducted in individual tanks. The ITS- 2 concentrations were performed by heating the contents of one tank and moving the heated liquor through a series of other tanks." (Wilson and Reep 1991, p. B-5).

In-tank solidification units 1 and 2 began operating on March 19, 1965, and February 17,1968 , respectively . ITS-1 was converted to a cooler for ITS-2 on August 24, 1971. Both units were shut down on June 30, 1974 (Anderson 1990).

\subsection{MISCELLANEOUS WASTE SOURCES AND EQUIPMENT}

Wastes from various other sources on the Hanford Site have been added to the tanks. Some wastes are from the 300 Area, 100 Area production reactors, various laboratories, and catch tanks. 
HNF-2944

Revision 0

\section{Critical Mass Laboratories}

The critical mass laboratories were used to study the physics of plutonium solutions and solids to avoid accidentally creating a criticality or self-sustained nuclear reaction. The first facility began operating in the 120 Building near 100-F in April 1950 and closed in December 1951. The second facility, the 209-E Building, was located next to the Strontium Semiworks and began operating in July 1961 (Ballinger and Hall 1991). The plutonium used in the lab was reprocessed in PUREX.

\section{4-AR, -BXR, and -CR Process Vaults}

Three of the process vaults are the 244-AR Vault, the 244-BXR Vault, and the 244-CR Vault. These vaults were composed of several process vessels or tanks used to prepare waste for treatment or storage. Specific wastes from tanks can be pumped temporarily to the vaults and later sent directly to desired tanks or processing facilities.

The AR Vault is located north and west of the A Tank Farm and was constructed in 1966. The vault facilities include a canyon building with process cells containing tanks. The AR Vault has been on standby since 1978 (Leach and Stahl 1993).

The 244-BXR Vault, located south of the BX Tank Farm began operating in 1952 (Rodenhizer 1987) and became inactive in 1956. The waste in the vault was difficult to handle, so the vault was jetted with high-pressure steam in 1976. The 244-BXR Vault was used to process sludge in the recovery of uranium from bismuth phosphate metal waste in the tanks (Rodenhizer 1987).

The 244-CR Vault was constructed in 1952 and is located south of the C Tank Farm (Leach and Stahl, 1993). Salt-well waste from the C Tank Farm is interimly stored in the CR Vault. The 244-CR Vault was used to process sludge in the recovery of uranium from bismuth phosphate metal waste in the tanks (Rodenhizer 1987).

\section{4-AR and 204-S Railroad Car Facilities}

The 204-AR rail car unloading facility was built in 1981 (Leach and Stahl 1993) and replaced the 204-S rail car unloading facility. The facilities were built for pumping liquid radioactive waste from tank cars and sending the waste to 200 East Area tank farms (Leach and Stahl 1993). 
HNF-2944

Revision 0

\section{REFERENCES}

Anderson, J. D., 1990, A History of the 200 Areas Tank Farms, WHC-MR-0132, Westinghouse Hanford Company, Richland, Washington.

Ballinger, M. Y., and R. B. Hall, 1991, A History of Major Hanford Facilities and Processes Involving Radioactive Material, PNL-6964 HEDR, Pacific Northwest Laboratory, Richland, Washington.

Brevick; C. H., 1997, Historical Tank Content Estimate for the Southwest Quadrant of the Hanford 200 West Area, HNF-SD-WM-ER-352, Rev. 1, Fluor Daniel Northwest, Inc., Richland, Washington.

Caudill, H. L., 1965, Design Criteria for a Second In-Tank Waste Solidification System, RL-SEP-499, General Electric Company, Richland, Washington.

Caudill, H. L., 1967, Design Criteria Modifications for Increased Capacity in the First InTank Solidifcation System, ISO-869, Isochem, Inc., Richland, Washington.

Duncan, D. R., B. A. Mayancsik, J. A. Pottmeyer, E. J. Vejvoda, J. A. Reddick, K. M. Sheldon, and M. I. Weyns, 1993, Characterization of Past and Present Solid Waste Streams from the Plutonium Finishing Plant, WHC-EP-0621, Westinghouse Hanford Company, Richland, Washington.

Gerber, M. S., 1992, Legend and Legacy: Fifty Years of Defense Production at the Hanford Site, WHC-MR-0293, Rev. 2, Westinghouse Hanford Company, Richland, Washington.

Gerber, M. S., 1993, A Brief History of the PUREX and UO ${ }_{3}$ Facilities, WHC-MR-0437, Westinghouse Hanford Company, Richland, Washington.

Gerber, M. S., 1994, Dramatic Change at T Plant, WHC-MR-0452, Westinghouse Hanford Company, Richland, Washington.

Gerber, M. S., 1996, Correspondence to C. V. Salois of ICF Kaiser Hanford, Westinghouse Hanford Company, Richland, Washington.

Godfrey, W. L., 1965, 242-T Evaporator Facility, Information Manual, RL-SEP-396, Hanford Atomic Products Operation, General Electric Company, Richland, Washington.

Jungfleisch, F. M., 1984, Preliminary Estimation of the Waste Inventories in Hanford Tanks Through 1980, SD-WM-TI-057, Rockwell Hanford Operations, Richland, Washington. 
Leach, C. E., and S. M. Stahl, 1993, Hanford Site Tank Farm Facilities Interim Safety Basis, Vols. 1 and 2, WHC-SD-WM-ISB-001, Westinghouse Hanford Company, Richland, Washington.

Rockwell, 1985, 200 Areas Fact Book, Rockwell Hanford Company, Richland, Washington.

Rodenhizer, D. G., 1987, Hanford Waste Tank Sluicing History, SD-WM-TI-302, Westinghouse Hanford Company, Richland, Washington.

Wilson, G. R., and I. E. Reep, 1991, A Plan to Implement Remediation of Waste Tank Safety Issues at the Hanford Site, WHC-EP-0422, Rev. 1, Westinghouse Hanford Company, Richland, Washington. 
HNF-2944

Revision 0

\section{APPENDIX C}

\section{SINGLE-SHELL TANK RETRIEVAL PROGRAM APPLICABLE TRI-PARTY AGREEMENT MILESTONES}


HNF-2944

Revision 0

This page intentionally left blank. 


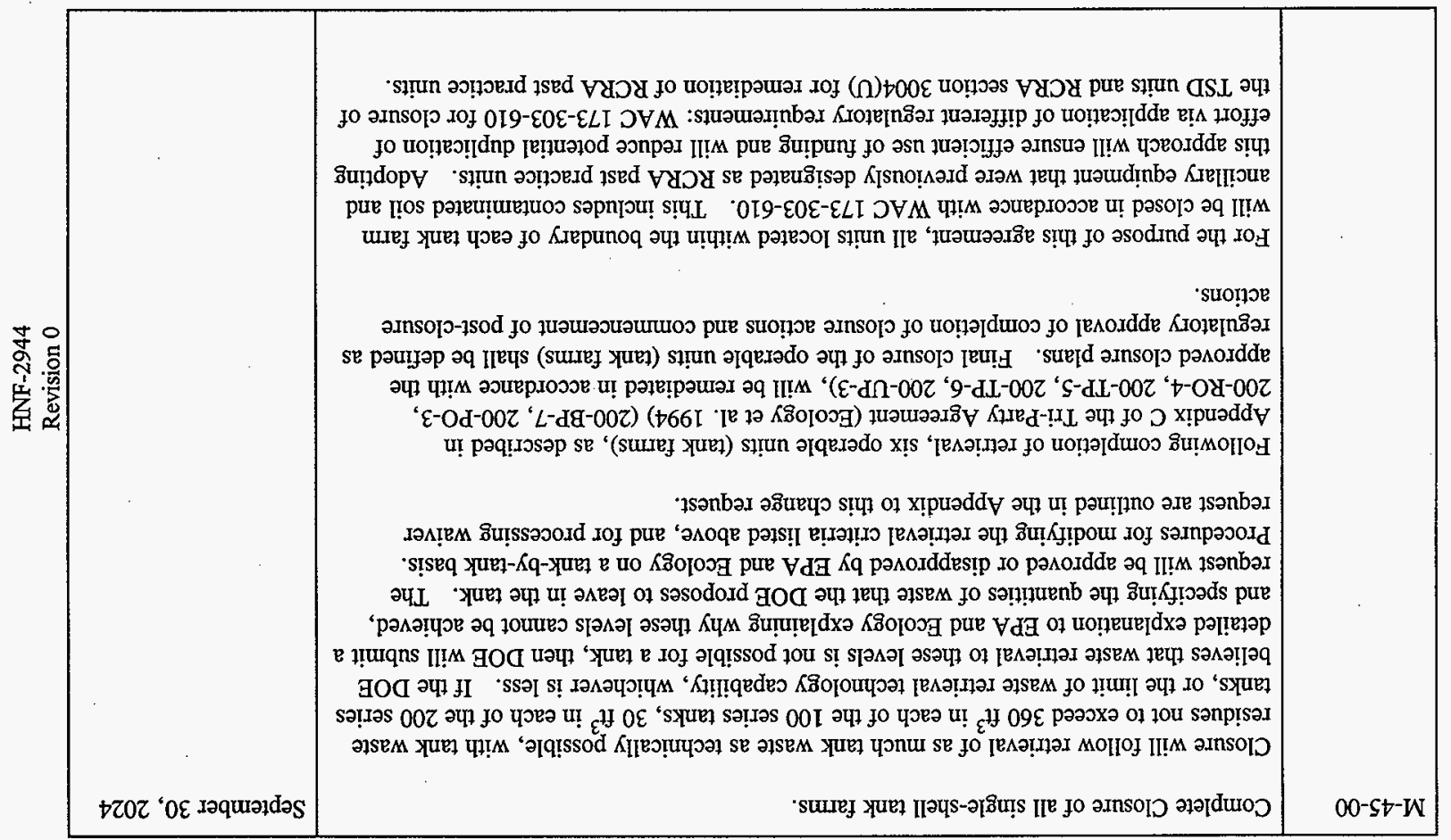

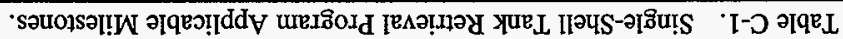




\begin{tabular}{|c|c|c|}
\hline 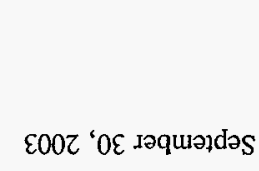 & 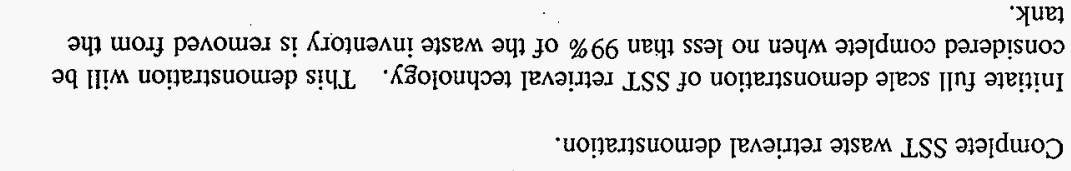 & $\begin{array}{r}I 0 L \\
-\mathcal{E} 0-\varsigma t-W\end{array}$ \\
\hline$\angle I 0 \tau$ 'OE دəquə]dəS & 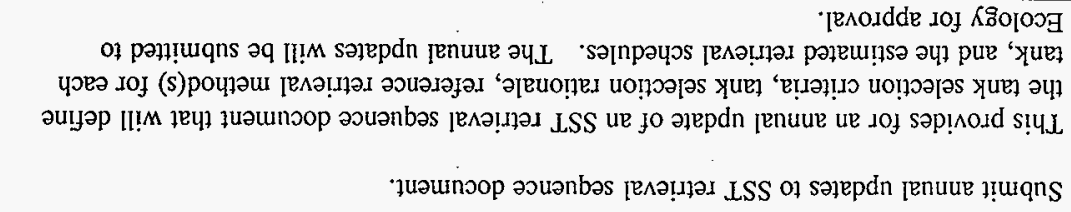 & $20-s_{5}-W$ \\
\hline 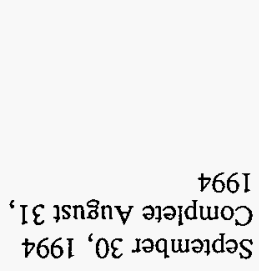 & 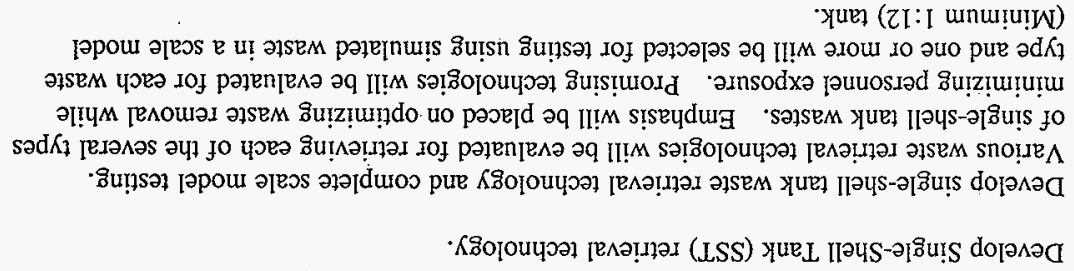 & $10-S+-W$ \\
\hline & 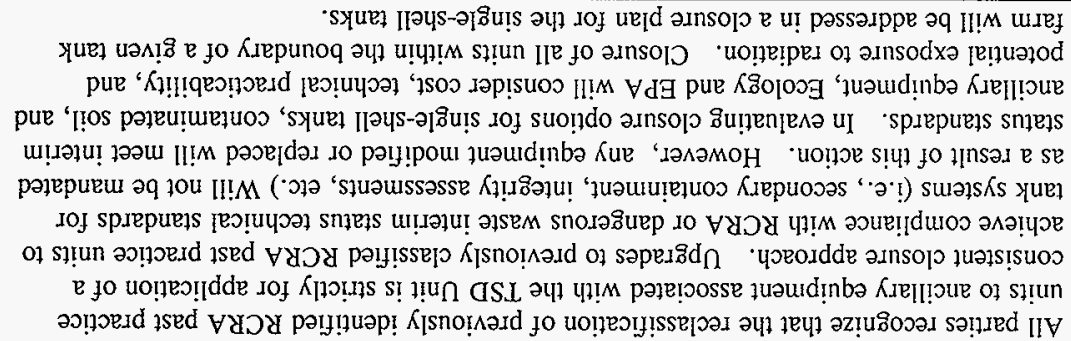 & \\
\hline
\end{tabular}

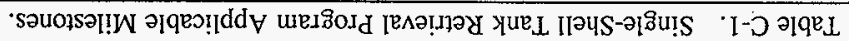


Table C-1. Single-Shell Tank Retrieval Program Applicable Milestones.

\begin{tabular}{|c|c|c|}
\hline $\begin{array}{l}\text { M-45-03- } \\
\text { T02 }\end{array}$ & $\begin{array}{l}\text { Initiate final retrieval demonstration of C- } 106 \text {. } \\
\text { Initiate final retrieval of tank } 241-\mathrm{C}-106 \text { to complete initial demonstration of SST retrieval } \\
\text { technologies. }\end{array}$ & June 30,2002 \\
\hline$M-45-03 A$ & $\begin{array}{l}\text { Initiate sluicing retrieval of } \mathrm{C}-106 . \\
\text { Initiate final retrieval of tank } 241-\mathrm{C}-106 \text { to resolve high heat issue and demonstrate waste } \\
\text { retrieval. }\end{array}$ & $\begin{array}{l}\text { October } 31,1997 . \\
\text { Formal change } \\
\text { request M-45-97-03 } \\
\text { was transmitted to } \\
\text { Ecology. Ecology } \\
\text { has not approved the } \\
\text { change request. }\end{array}$ \\
\hline $\begin{array}{l}\text { M-45-04- } \\
\text { T01 }\end{array}$ & $\begin{array}{l}\text { Provide initial single-shell tank retrieval systems. } \\
\text { Complete construction and related testing of the initial SST retrieval systems. This } \\
\text { milestone will provide retrieval systems for an entire single-shell tank farm or an equivalent } \\
\text { number of tanks. }\end{array}$ & November 30,2003 \\
\hline $\begin{array}{l}\text { M-45-04- } \\
\text { T02 }\end{array}$ & Complete design for the initial SST retrieval systems. & December 31,2000 \\
\hline $\begin{array}{l}M-45-04- \\
\text { T03 }\end{array}$ & Complete construction for the initial SST retrieval systems. & June 30,2003 \\
\hline$M-45-04 A$ & Complete conceptual design for the initial SST Retrieval Systems. & $\begin{array}{l}\text { April } 30,1997 \\
\text { Complete } \\
\text { February } 19,1997\end{array}$ \\
\hline
\end{tabular}


Table C-1. Single-Shell Tank Retrieval Program Applicable Milestones.

\begin{tabular}{|c|c|c|}
\hline$M-45-05$ & $\begin{array}{l}\text { Retrieve waste from all remaining single-shell tanks. } \\
\text { Complete waste retrieval from all remaining single-shell tanks. Retrieval standards and } \\
\text { completion definitions are provided under the major milestone. The schedule reflects } \\
\text { retrieval activities on a farm-by-farm basis. It also allows flexibility to retrieve tanks from } \\
\text { various farms if desired to support safety issue resolution, pretreatment or disposal feed } \\
\text { requirements, or other priorities. }\end{array}$ & September 30,2018 \\
\hline $\begin{array}{l}\text { M-45-05- } \\
\text { T01 }\end{array}$ & Initiate tank waste retrieval from one single-shell tank. & December 31, 2003 \\
\hline $\begin{array}{l}\text { M-45-05- } \\
\text { T02 }\end{array}$ & Initiate tank waste retrieval from two additional single-shell tanks. & September 30,2004 \\
\hline $\begin{array}{l}\text { M-45-05- } \\
\text { T03 }\end{array}$ & Initiate tank waste retrieval from three additional single-shell tanks. & September 30,2005 \\
\hline $\begin{array}{l}\text { M-45-05- } \\
\text { T04 }\end{array}$ & Initiate tank waste retrieval from four additional single-shell tanks. & September 30,2006 \\
\hline $\begin{array}{l}\text { M-45-05- } \\
\text { T05 }\end{array}$ & Initiate tank waste retrieval from five additional single-shell tanks. & September 30,2007 \\
\hline $\begin{array}{l}\text { M-45-05- } \\
\text { T06 }\end{array}$ & Initiate tank waste retrieval from five additional single-shell tanks. & September 30,2008 \\
\hline $\begin{array}{l}\text { M-45-05- } \\
\text { T07 }\end{array}$ & Initiate tank waste retrieval from seven additional single-shell tanks. & September 30,2009 \\
\hline $\begin{array}{l}\text { M-45-05- } \\
\text { T08 }\end{array}$ & Initiate tank waste retrieval from eight additional single-shell tanks. & September 30,2010 \\
\hline $\begin{array}{l}\text { M-45-05- } \\
\text { T09 }\end{array}$ & Initiate tank waste retrieval from ten additional single-shell tanks. & September 30,2011 \\
\hline $\begin{array}{l}\text { M-45-05- } \\
\text { T10 }\end{array}$ & Initiate tank waste retrieval from 12 additional single-shell tanks. & September 30,2012 \\
\hline
\end{tabular}


Table C-1. Single-Shell Tank Retrieval Program Applicable Milestones.

\begin{tabular}{|c|c|c|}
\hline $\begin{array}{l}\text { M-45-05- } \\
\text { T11 }\end{array}$ & Initiate tank waste retrieval from 14 additional single-shell tanks. & September 30,2013 \\
\hline $\begin{array}{l}M-45-05- \\
\mathrm{T} 12\end{array}$ & Initiate tank waste retrieval from 17 additional single-shell tanks. & September 30,2014 \\
\hline $\begin{array}{l}\text { M-45-05- } \\
\mathrm{T} 13\end{array}$ & Initiate tank waste retrieval from 20 additional single-shell tanks. & September 30,2015 \\
\hline $\begin{array}{l}\mathrm{M}-45-05- \\
\mathrm{T} 14\end{array}$ & Initiate tank waste retrieval from 20 additional single-shell tanks. & September 30,2016 \\
\hline $\begin{array}{l}\text { M-45-05- } \\
\text { T15 }\end{array}$ & Initiate tank waste retrieval from 20 additional single-shell tanks. & September 30,2017 \\
\hline$M-45-06$ & $\begin{array}{l}\text { Complete closure of all single-shell tank farms. } \\
\text { The single-shell tank closure work plan will be prepared describing the work integration } \\
\text { process for single-shell tank closures and status of work integration process. Known issues } \\
\text { will be identified and an explanation will be given on how these issues are being addressed. } \\
\text { This work plan will be provided to Ecology for review/comment and will be used as a road } \\
\text { map for closure of the single-shell tanks. Because of the uncertainties in the closure } \\
\text { process, the work plan will evolve as these uncertainties are resolved and eventually it will } \\
\text { become the SST closure/post-closure plan(s) issued for Ecology's approval under subsequent } \\
\text { Tri-Party Agreement interim milestones. Major work areas covered in the work plan will } \\
\text { include waste retrieval, operable units characterization, technologies development to support } \\
\text { closure, regulatory pathway and strategy for achieving closure. }\end{array}$ & September 30,2024 \\
\hline $\begin{array}{l}\text { M-45-06- } \\
\text { T01 }\end{array}$ & $\begin{array}{l}\text { Submit tank closure/post-closure plan for selected closure demonstration operable unit or } \\
\text { tank farm to Ecology for approval. }\end{array}$ & $11 / 30 / 2004$ \\
\hline $\begin{array}{l}\mathrm{M}-45-06- \\
\mathrm{T} 02\end{array}$ & $\begin{array}{l}\text { Ecology will issue final closure/post-closure plan for selected closure demonstration operable } \\
\text { unit or tank farm. }\end{array}$ & $9 / 30 / 2006$ \\
\hline
\end{tabular}


Table C-1. Single-Shell Tank Retrieval Program Applicable Milestones.

\begin{tabular}{|c|c|c|}
\hline $\begin{array}{l}\text { M-45-06- } \\
\text { T03 }\end{array}$ & $\begin{array}{l}\text { Initiate closure actions on an operable unit or tank farm basis. Closure shall follow } \\
\text { completion of the retrieval actions under proposed milestone M- } 45-05 \text {. Closure will be } \\
\text { defined in an approved closure plan for the demonstration farm. Final closure is defined as } \\
\text { regulatory approval of completion of closure actions. }\end{array}$ & $3 / 31 / 2012$ \\
\hline $\begin{array}{l}\text { M-45-06- } \\
\text { T04 }\end{array}$ & Complete closure actions on one operable unit or tank farm. & $3 / 31 / 2014$ \\
\hline M-45-08 & $\begin{array}{l}\text { Establish full scale capability for mitigation of waste tank leakage during retrieval sluicing } \\
\text { operations. }\end{array}$ & $\begin{array}{l}\text { June } 30,2003 \text { This } \\
\text { milestone established } \\
\text { by change request M- } \\
45-95-01 \text { which was } \\
\text { approved on } 5 / 15 / 95 \text {. }\end{array}$ \\
\hline $\mathrm{M}-45-08 \mathrm{~A}$ & $\begin{array}{l}\text { Complete system design and operating strategy for tank leak monitoring and mitigation for } \\
\text { systems to be used in conjunction with initial retrieval systems for SSTs. }\end{array}$ & $\begin{array}{l}\text { December } 31,2000 \text {. } \\
\text { This milestone } \\
\text { established by change } \\
\text { request M-45-95-01 } \\
\text { which was approved } \\
\text { on } 5 / 15 / 95 \text {. } \\
\end{array}$ \\
\hline M-45-08B & $\begin{array}{l}\text { Complete demonstration and installation of leak monitoring and mitigation system for initial } \\
\text { SST retrieval. }\end{array}$ & $\begin{array}{l}\text { June } 30,2003 \text {. This } \\
\text { milestone established } \\
\text { by change request } M- \\
45-95-01 \text { which was } \\
\text { approved on } 5 / 15 / 95 .\end{array}$ \\
\hline M-45-09A & $\begin{array}{l}\text { Submit annual progress reports on the development of waste tank leak monitoring/detection } \\
\text { and mitigation activities in support of m- } 45-08 \text {. } \\
\\
\text { Reports will provide a description of work accomplished under M-45-08, technologies, } \\
\text { applications, cost, schedule, and technical data. Reports will also evaluate demonstrations } \\
\text { performed by DOE and private industry for applicability to SST retrieval and provide } \\
\text { recommendations for further testing for use in retrieval operations. }\end{array}$ & $\begin{array}{l}\text { September 30, } 1996 . \\
\text { Completed } 9 / 26 / 96 .\end{array}$ \\
\hline
\end{tabular}


Table C-1. Single-Shell Tank Retrieval Program Applicable Milestones.

\begin{tabular}{|c|c|c|}
\hline$M-45-09 B$ & $\begin{array}{l}\text { Submit annual progress reports on the development of waste tank leak monitoring/detection } \\
\text { and mitigation activities in support of M- } 45-08 \text {. } \\
\text { Reports will provide a description of work accomplished under M-45-08, technologies, } \\
\text { applications, cost, schedule, and technical data. Reports will also evaluate demonstrations } \\
\text { performed by DOE and private industry for applicability to SST retrieval and provide } \\
\text { recommendations for further testing for use in retrieval operations. }\end{array}$ & $\begin{array}{l}\text { September } 30,1997 . \\
\text { Completed 9/25/97. }\end{array}$ \\
\hline$M-45-09 C$ & $\begin{array}{l}\text { Submit annual progress reports on the development of waste tank leak monitoring/detection } \\
\text { and mitigation activities in support of } \mathrm{M}-45-08 \text {. } \\
\text { Reports will provide a description of work accomplished under } \mathrm{M}-45-08 \text {, technologies, } \\
\text { applications, cost, schedule, and technical data. Reports will also evaluate demonstrations } \\
\text { performed by DOE and private industry for applicability to SST retrieval and provide } \\
\text { recommendations for further testing for use in retrieval operations. }\end{array}$ & $\begin{array}{l}\text { September } 30,1998 \text {. } \\
\text { This milestone } \\
\text { established by change } \\
\text { request } \mathrm{M}-45-95-01 \\
\text { which was approved } \\
\text { on } 5 / 15 / 95 \text {. }\end{array}$ \\
\hline M-45-09D & $\begin{array}{l}\text { Submit annual progress reports on the development of waste tank leak monitoring/detection } \\
\text { and mitigation activities in support of M-45-08. } \\
\text { Reports will provide a description of work accomplished under M-45-08, technologies, } \\
\text { applications, cost, schedule, and technical data. Reports will also evaluate demonstrations } \\
\text { performed by DOE and private industry for applicability to SST retrieval and provide } \\
\text { recommendations for further testing for use in retrieval operations. }\end{array}$ & $\begin{array}{l}\text { September } 30,1999 . \\
\text { This milestone } \\
\text { established by change } \\
\text { request M- } 45-95-01 \\
\text { which was approved } \\
5 / 15 / 95 \text {. }\end{array}$ \\
\hline$M-45-09 E$ & $\begin{array}{l}\text { Submit annual progress reports on the development of waste tank leak monitoring/detection } \\
\text { and mitigation activities in support of } \mathrm{M}-45-08 \text {. } \\
\text { Reports will provide a description of work accomplished under } \mathrm{M}-45-08 \text {, technologies, } \\
\text { applications, cost, schedule, and technical data. Reports will also evaluate demonstrations } \\
\text { performed by DOE and private industry for applicability to SST retrieval and provide } \\
\text { recommendations for further testing for use in retrieval operations. }\end{array}$ & $\begin{array}{l}\text { September } 30,2000 \text {. } \\
\text { This milestone } \\
\text { established by change } \\
\text { request M- } 45-95-01 \\
\text { which was approved } \\
5 / 15 / 95 \text {. }\end{array}$ \\
\hline
\end{tabular}


Table C-1. Single-Shell Tank Retrieval Program Applicable Milestones.

\begin{tabular}{|c|c|c|}
\hline$M-45-09 F$ & $\begin{array}{l}\text { Submit annual progress reports on the development of waste tank leak monitoring/detection } \\
\text { and mitigation activities in support of M-45-08. } \\
\text { Reports will provide a description of work accomplished under M-45-08, technologies, } \\
\text { applications, cost, schedule, and technical data. Reports will also evaluate demonstrations } \\
\text { performed by DOE and private industry for applicability to SST retrieval and provide } \\
\text { recommendations for further testing for use in retrieval operations. }\end{array}$ & $\begin{array}{l}\text { September } 30,2001 \text {. } \\
\text { This milestone } \\
\text { established by change } \\
\text { request M-45-95-01 } \\
\text { which was approved } \\
\text { on } 5 / 15 / 95 \text {. }\end{array}$ \\
\hline$M-45-09 G$ & $\begin{array}{l}\text { Submit annual progress reports on the development of waste tank leak monitoring/detection } \\
\text { and mitigation activities in support of M-45-08. } \\
\text { Reports will provide a description of work accomplished under M-45-08, technologies, } \\
\text { applications, cost, schedule, and technical data. Reports will also evaluate demonstrations } \\
\text { performed by DOE and private industry for applicability to SST retrieval and provide } \\
\text { recommendations for further testing for use in retrieval operations. }\end{array}$ & $\begin{array}{l}\text { September } 30,2002 \text {. } \\
\text { This milestone } \\
\text { established by change } \\
\text { request } \mathrm{M}-45-95-01 \\
\text { which was approved } \\
\text { on } 5 / 15 / 95 \text {. }\end{array}$ \\
\hline $\mathrm{M}-45-09 \mathrm{H}$ & $\begin{array}{l}\text { Submit annual progress reports on the development of waste tank leak monitoring/detection } \\
\text { and mitigation activities in support of } \mathrm{M}-45-08 \text {. } \\
\text { Reports will provide a description of work accomplished under } \mathrm{M}-45-08 \text {, technologies, } \\
\text { applications, cost, schedule, and technical data. Reports will also evaluate demonstrations } \\
\text { performed by DOE and private industry for applicability to SST retrieval and provide } \\
\text { recommendations for further testing for use in retrieval operations. }\end{array}$ & $\begin{array}{l}\text { September } 30,2003 \text {. } \\
\text { This milestone } \\
\text { established by change } \\
\text { request M-45-95-01 } \\
\text { which was approved } \\
\text { on } 5 / 15 / 95 \text {. }\end{array}$ \\
\hline
\end{tabular}

Reference: Ecology, EPA, and DOE, 1994, Hanford Federal Facility Agreement and Consent Order, as amended, Washington State Department of Ecology, U.S. Environmental Protection Agency, and U.S. Department of Energy, Olympia, Washington. 
HNF-2944

Revision 0

\section{APPENDIX D}

\section{TANK WASTE REMEDIATION SYSTEM EXTERNALLY IMPOSED REQUTREMENTS}


HNF-2944

Revision 0

This page intentionally left blank. 
HNF-2944

Revision 0

APPENDIX D

TANK WASTE REMEDIATION SYSTEM EXTERNALLY IMPOSED REQUIREMENTS

Table D-1. Tank Waste Remediation System Externally Imposed Requirements--Code of Federal Regulations. (4 Sheets)

\begin{tabular}{|c|c|c|}
\hline \multicolumn{3}{|c|}{ Code of Federal Regulations } \\
\hline $\begin{array}{l}\text { External code or } \\
\text { regulation }\end{array}$ & Title & $\begin{array}{l}\text { Comment } \\
\text { (significant interest areas) }\end{array}$ \\
\hline $10 \mathrm{CFR} 20$ & $\begin{array}{l}\text { Standards for Protection Against } \\
\text { Radiation }\end{array}$ & - Access controls \\
\hline 10 CFR 61 & $\begin{array}{l}\text { Licensing Requirements for Land } \\
\text { Disposal of Radioactive Waste }\end{array}$ & $\begin{array}{l}\text { - Protection of the general population from releases of } \\
\text { radiation. Equivalent annual dose limits for public exposure } \\
\text { to contaminated groundwater, surface water, air, soil, } \\
\text { plants, and animals } \\
\text { - Protection of individuals from inadvertent intrusion } \\
\text { - Burial requirements for Class A and Class C waste } \\
\text { Specifies pertinent onsite immobilized low-level waste } \\
\text { burial requirements } \\
\text { - Classification of wastes - Classification specifications for } \\
\text { Class A and Class C waste. Designates whether } \\
\text { immobilized waste may be in general buried onsite or if it is } \\
\text { necessary to dispose of in an isolated deep repository } \\
\text { - Minimum requirements for all waste classes and are } \\
\text { intended to facilitate handling at the disposal site and } \\
\text { provide protection of health and safety of personnel at the } \\
\text { disposal site }\end{array}$ \\
\hline 10 CFR 830 & Nuclear Safety Management & $\begin{array}{l}\text { - Applicable to Quality Assurance Program, personnel } \\
\text { training, quality improvement }\end{array}$ \\
\hline 10 CFR 835 & Occupational Radiation Protection & - Occupational exposure limits for general employees \\
\hline 10 CFR 962 & By-Product Material & $\begin{array}{l}\text { - DOE obligation to RCRA - Defines DOE's obligations to } \\
\text { the RCRA with regard to radioactive waste substances }\end{array}$ \\
\hline 29 CFR 1910 & $\begin{array}{l}\text { Occupational Safety and Health } \\
\text { Standards }\end{array}$ & - Occupational Safety and Health Standards regulations \\
\hline
\end{tabular}


HNF-2944

Revision 0

Table D-1. Tank Waste Remediation System Externally Imposed Requirements--Code of Federal Regulations. (4 Sheets)

\begin{tabular}{|c|c|c|}
\hline \multicolumn{3}{|c|}{ Code of Federal Regulations } \\
\hline $\begin{array}{l}\text { External code or } \\
\text { regulation }\end{array}$ & Title & $\begin{array}{c}\text { Comment } \\
\text { (significant interest areas) }\end{array}$ \\
\hline 40 CFR 50 & $\begin{array}{l}\text { National Primary and Secondary } \\
\text { Ambient Air Quality Standards }\end{array}$ & $\begin{array}{l}\text { - Ambient air quality standards - primary limits for sulfur } \\
\text { oxides } \\
\text { - Ambient air quality standards - secondary limits for sulfur } \\
\text { oxides } \\
\text { - Ambient air quality standards - primary and secondary } \\
\text { limits of particuiate matter } \\
\text { - Ambient air quality standards - primary limits for carbon } \\
\text { monoxide } \\
\text { - Ambient air quality standards - primary and secondary } \\
\text { limits for ozone } \\
\text { - Ambient air quality standards - primary and secondary for } \\
\text { nitrogen dioxide } \\
\text { - Ambient air quality standards - primary and secondary } \\
\text { standards for lead }\end{array}$ \\
\hline 40 CFR 61 & $\begin{array}{l}\text { National Emission Standards for } \\
\text { Hazardous Air Pollutants }\end{array}$ & $\begin{array}{l}\text { - Dose limit from DOE facility. Emissions to ambient air } \\
\text { from DOE facilities will not exceed limit to any member of } \\
\text { the public in } 1 \text { year }\end{array}$ \\
\hline 40 CFR 141 & $\begin{array}{l}\text { National Primary Drinking Water } \\
\text { Regulations }\end{array}$ & - \\
\hline 40 CFR 191 & $\begin{array}{l}\text { Environmental Radiation } \\
\text { Protection Standards for } \\
\text { Management and Disposal of Spent } \\
\text { Nuclear Fuel, High-Level and } \\
\text { Transuranic Radioactive Wastes }\end{array}$ & $\begin{array}{l}\text { - Public dose limits. Management and storage of spent } \\
\text { nuclear fuel, high-level, or transuranic radioactive wastes } \\
\text { annual dose equivalents to any member of the public in the } \\
\text { general environment. }\end{array}$ \\
\hline
\end{tabular}


Table D-1. Tank Waste Remediation System Externally Imposed Requirements--Code of Federal Regulations. (4 Sheets)

\begin{tabular}{|c|c|c|}
\hline \multicolumn{3}{|c|}{ Code of Federal Regulations } \\
\hline $\begin{array}{l}\text { External code or } \\
\text { regulation }\end{array}$ & Title & $\begin{array}{c}\text { Comment } \\
\text { (significant interest areas) }\end{array}$ \\
\hline 40 CFR 264 & $\begin{array}{l}\text { Standards for Owners and } \\
\text { Operators of Hazarcous Waste } \\
\text { Treatment, Storage, and Disposal } \\
\text { Facilities }\end{array}$ & $\begin{array}{l}\text { - Storage requirements - Hazardous wastes must not be } \\
\text { placed in tank system if they could cause the tank or } \\
\text { associated ancillary equipment and containment system to } \\
\text { rupture, leak, corrode, or otherwise fail } \\
\text { - Storage requirements - The owner or operator must use } \\
\text { appropriate controls and practices to prevent spills and } \\
\text { overflows from tank to containment systems } \\
\text { - Storage requirements - Ignitable or reactive waste must not } \\
\text { be placed in tank systems, unless: (1) the waste is treated, } \\
\text { rendered, or mixed so that the waste is protected from a } \\
\text { material or condition that may cause the waste to ignite or } \\
\text { react or } 40 \text { CFR } 264.17 \text { (b) is complied with, or (2) the tank } \\
\text { system is used solely for emergencies. Stored ignitable or } \\
\text { reactive wastes must comply with requirement for protective } \\
\text { distances from the public. } \\
\text { - Storage requirements - Incornpatible wastes or } \\
\text { incompatible wastes and materials must not be placed in } \\
\text { same tank system, unless } 40 \text { CFR } 264.17 \text { (b) is complied } \\
\text { with } \\
\text { - Closure requirement - Decontamination at closure of a } \\
\text { containment building. Owner/operator must decontaminate } \\
\text { all waste residues, contaminated containment system } \\
\text { components (liners, etc.), contaminated soils, and structures } \\
\text { and equipment contaminated with waste and leachate, and } \\
\text { manage as a hazardous waste. } \\
\text { - Waste containment system closure requirements. At } \\
\text { closure, all hazardous waste and hazardous waste residues } \\
\text { must be removed from the containment system. Remaining } \\
\text { containers, liners, bases, and soil containing or } \\
\text { contaminated with hazardous waste or residues must be } \\
\text { decontaminated or removed. }\end{array}$ \\
\hline 40 CFR 265 & $\begin{array}{l}\text { Interim Status Stancards for } \\
\text { Owners and Operators of } \\
\text { Hazardous Waste Treatment, } \\
\text { Storage, and Disposal Facilities }\end{array}$ & $\begin{array}{l}\text { - Secondary containment } \\
\text { - Spill convention and controls } \\
\text { - Incompatible/ignitable wastes }\end{array}$ \\
\hline 40 CFR 268 & Land Disposal Restrictions & $\begin{array}{l}\text { - Applicable exceptions for which otherwise prohibited } \\
\text { wastes may be disposed of in a landfill } \\
\text { - Certain wastes prohibited from land disposal } \\
\text { - Applicability of treatment standards }\end{array}$ \\
\hline
\end{tabular}


HNF-2944

Revision 0

Table D-1. Tank Waste Remediation System Externally Imposed Requirements--Code of Federal Regulations. (4 Sheets)

\begin{tabular}{|l|l|c|}
\hline $\begin{array}{c}|c| \\
\text { External code or } \\
\text { regulation }\end{array}$ & \multicolumn{1}{|c|}{ Title } & \multicolumn{1}{|c|}{$\begin{array}{c}\text { Code of Federal Regulations } \\
\text { (significant interest areas) }\end{array}$} \\
\hline 40 CFR 279 & $\begin{array}{l}\text { Standards for the Management of } \\
\text { Used Oil }\end{array}$ & - Used oil handling \\
\hline 40 CFR 761 & $\begin{array}{l}\text { Polychlorinated Biphenyls (PCBs), } \\
\text { Manufacturing, Processing, } \\
\text { Distribution in Commerce, and } \\
\text { Use Prohibitions }\end{array}$ & \\
\hline
\end{tabular}

$\mathrm{CFR}=$ Code of Federal Regulations.

DOE $=$ U.S. Department of Energy.

$\mathrm{RCRA}=$ Resource Conservation and Recovery Act of 1976.

Table D-2. Tank Waste Remediation System Externally Imposed Requirements-Washington Administrative Code.

\begin{tabular}{|c|c|c|}
\hline \multicolumn{3}{|c|}{ Washington Administrative Code } \\
\hline $\begin{array}{l}\text { External code or } \\
\text { regulation }\end{array}$ & Title & $\begin{array}{c}\text { Comment } \\
\text { (significant interest areas) } \\
\end{array}$ \\
\hline WAC $173-200$ & $\begin{array}{l}\text { Water Quality Standards for Ground } \\
\text { Waters of the State of Washington }\end{array}$ & - Liquid effluent discharge to the environment \\
\hline WAC 173-201A & $\begin{array}{l}\text { Water Quality Standards for Surface } \\
\text { Waters of the State of Washington }\end{array}$ & - Liquid effluent discharge to the environment \\
\hline WAC 173-303 & Dangerous Waste Regulations & -- \\
\hline WAC $173-360$ & Underground Storage Tank Regulations & - Secondary containment and leak detection \\
\hline WAC $173-400$ & $\begin{array}{l}\text { General Regulations for Air Pollution } \\
\text { Sources }\end{array}$ & $\begin{array}{l}\text { - Nonradioactive air emissions, new source } \\
\text { review/notice of construction, source registration }\end{array}$ \\
\hline WAC 173-401 & Operating Permit Regulation & -- \\
\hline WAC $173-460$ & $\begin{array}{l}\text { Controls for New Sources of Toxic Air } \\
\text { Pollutants }\end{array}$ & - Nonradioactive air emissions, toxic air pollutants \\
\hline WAC $173-480$ & $\begin{array}{l}\text { Ambient Air Quality Standards and } \\
\text { Emission Limits for Radionuclides }\end{array}$ & -- \\
\hline WAC 246-247 & Radiation Protection--Air Emissions & $\begin{array}{l}\text { - Ambient air quality standards and emission } \\
\text { standards will be those promulgated by Ecology in } \\
\text { WAC } 173-480\end{array}$ \\
\hline
\end{tabular}


HNF-2944

Revision 0

Table D-3. Tank Waste Remediation System Externally Imposed Requirements-U.S. Department of Energy Orders and Other Federal Regulations.

\begin{tabular}{|c|c|c|}
\hline \multicolumn{3}{|c|}{ DOE Orders and other federal regulations } \\
\hline $\begin{array}{l}\text { External code or } \\
\text { regulation }\end{array}$ & Titie & $\begin{array}{c}\text { Comment } \\
\text { (significant interest areas) }\end{array}$ \\
\hline \multicolumn{3}{|c|}{$\begin{array}{l}\text { See the PHMC contract,* Appendix C, Section J, Part III - List of Documents Exhibits and Other Attachments, } \\
\text { DOE Orders and Directives. (NOTE: This list is still undergoing change so it is necessary to refer to the latest } \\
\text { list from Contracting to obtain a complete listing of all the codes.) }\end{array}$} \\
\hline \multicolumn{3}{|c|}{ Other regulations and requirements } \\
\hline $\begin{array}{l}\text { External code or } \\
\text { regulation }\end{array}$ & Title & $\begin{array}{c}\text { Comment } \\
\text { (significant interest areas) }\end{array}$ \\
\hline RCRA-B(DW)(940829) & $\begin{array}{l}\text { Dangerous Waste Portion of the } \\
\text { RCRA Permit for the Treatment, } \\
\text { Storage, and Disposal of Hazardous } \\
\text { Waste }\end{array}$ & $\begin{array}{l}\text { - Standards for hazardous treatment, storage, } \\
\text { and/or disposal facilities }\end{array}$ \\
\hline $\begin{array}{l}\text { Project Hanford policies } \\
\text { and procedures }\end{array}$ & (Numerous) & - \\
\hline $\begin{array}{l}\text { Hanford Site Radiological } \\
\text { Control Manual, } \\
\text { Sections } 111,112\end{array}$ & $\cdots$ & - Summary of health and safety regulations \\
\hline PNNL-11107 & $\begin{array}{l}\text { Climatological Data Summary } 1995 \\
\text { with Historical Data - Hanford Site }\end{array}$ & -- \\
\hline
\end{tabular}

*RL, 1996, Project Hanford Management Contract (PHMC), DE-AC06-96RL13200, U.S. Department of Energy, Richland Operations Office, Richland, Washington. 
HNF-2944

Revision 0

This page intentionally left blank. 
HNF-2944

Revision 0

\section{APPENDIX E}

\section{SINGLE-SHELL TANK RETRIEVAL INFORMATION AND TOOLS}


HNF-2944

Revision 0

This page intentionally left blank. 
HNF-2944

Revision 0

APPENDIX E

SINGLE-SHELL TANK RETRIEVAL INFORMATION AND TOOLS

This section discusses current and needed knowledge on the existing conditions of the tanks and its contents, retrieval technology and infrastructure, and analytical tools used in systems deployment decision-making.

\section{E1.0 NEEDS ANALYSIS}

The program will determine what information is needed in order to optimize the retrieval program. This will be based on understanding the existing conditions of the tanks and their contents, tank integrity, tank configurations, infrastructure and retrieval technologies. The program will then identify what additional data will need to be developed in order to proceed and what the program must do in order to get that data.

\section{E1.1 TANK WASTE COMPOSITION}

Both physical and chemical characteristics of the waste in single-shell tanks (SSTs) must be known to accomplish the mission of retrieving the waste from the tanks. Physical data will be required to ensure the correct retrieval technology is deployed in the tank and chemical data will be required to support transport, blending and feed delivery. Existing composition information is available for SSTs through the Best-Basis Inventory (BBI) (Kupfer et al. 1997) and reported in the Tank Waste Characterization Reports.

Additional waste chemical, physical, and radiological properties will be needed to support the Tank Waste Retrieval mission and will be achieved by sampling and analysis of selected tanks. A process for determining the specific chemical and physical characteristics of tank wastes has been developed (Certa 1998, Crawford 1998). Experience is being gained on applying these data quality objectives procedures on the double-shell tanks.

Inventory Assessments. The inventories of chemical and radionuclide components in the SST waste provide information for retrieval sequence activities. This activity supports preparation of process flowsheets, information on achieving waste composition analysis requirements and identification of hazardous components affecting both retrieval and waste disposal requirements. 
To provide a standard waste inventory characterization source term for the various waste management activities (Hodgson and LeClair 1996), an evaluation of available chemical and radionuclide information for SST wastes was performed, and a BBI has been established for all SSTs (Kupfer et al. 1997).

Very few of the SSTs are full of waste. Thirteen of the $22.9-\mathrm{m}(75-\mathrm{ft})$ diameter SSTs

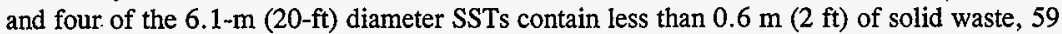
contain less than $1.5 \mathrm{~m}(5 \mathrm{ft})$, and 80 of the $13322.9-\mathrm{m}(75-\mathrm{ft})$ diameter SSTs contain less than $3.7 \mathrm{~m}(12 \mathrm{ft})$ of waste.

Many SSTs contain hardware, failed equipment and materials in addition to the typical waste sludge, saltcake, and liquids. These materials were discarded before November 1980 as part of storage and transfer operations, full-scale experiments, and development activities. Discarded equipment included large installed hardware (e.g., airlift circulators, thermocouple trees, steam coils, and sluicers). Materials added to some tanks include experimental fuel elements, cobalt slugs, diatomaceous earth, Portland cement, and other miscellaneous items such as sample bottles, measuring tapes, tools, sludge weights, and rocks.

Saltcake. Saltcake was generated by evaporation and crystallization of various sodium salts from solution. The primary constituents of saltcake are sodium nitrate, sodium nitrite, sodium aluminate, sodium carbonate, sodium hydroxide, sodium sulfate and sodium phosphate. Saltcake includes various radioactive and heavy metal contaminants. Saltcake was generated by self-concentration, by in-tank evaporation, and by external evaporators.

Sludge. Sludge was generated by the precipitation from solution of metal hydroxides. The sludge contains radioactive contaminants and heavy metals. In addition to its chemical and radiological composition, sludge has been characterized by its density, water content, and thermal stability. Limited information on viscosity, and particle size is also available. Empirical information on the hardness of the sludge can be obtained from core drilling logbooks.

\section{E1.2 TANK INTEGRITY}

Tank integrity can be discussed on two levels: (1) Structural Integrity--will the tanks collapse or rupture, and (2) Liquid Integrity--will the tanks maintain confinement of liquids. The SSTs derive their structural integrity from the steel re-enforced concrete structure that makes up the tank. They derive their liquid integrity from the carbon steel liner that makes up the confinement boundary for the SSTs. An expert Tank Structural Integrity Panel found that the SSTs are structurally sound (Han 1996). While the SSTs are believed to be structurally sound, the liquid integrity of many of these tanks is suspect.

The most likely failure mechanism for the SSTs is corrosion. The corrosion mechanisms that apply to the Hanford Site SSTs are stress corrosion cracking, pitting/crevice corrosion, uniform corrosion, and hydrogen embrittlement. Accurate determination of SST failure 
mechanisms have been difficult to verify due to the inability to physically examine the tanks. Literature surveys of carbon steel data in environments similar to the SST wastes, and a review of the work performed at the Savannah River Site where similar wastes are stored in similar carbon steel tanks has determined that stress corrosion cracking is the primary failure mechanism (Anantatmula et al. 1994). This failure mechanism results in numerous small cracks in the tank weld heat affect zone. Leakage rates are on the order of $1.1 \mathrm{ml} / \mathrm{min}$ (.03 gal $/ \mathrm{min}$ ). These small cracks require a "driving" head of liquid for leakage to occur. Tank retrieval mechanisms that minimize this hydraulic head will be critical to deal with waste retrieval in a assumed leaking tanks.

Two of the SSTs (241-T-106 and 241-SX-110) have been damaged through waste process actions during production operations (sudden stresses and prolonged high temperatures, corrosion conditions, and structural and construction inadequacies). These conditions will not be present during retrieval operations. Specific assessments for these (and other) damaged tanks will be required in the retrieval system development process.

Tank Integrity Assessments. To assess the potential for failure of the SSTs that are presumably sound (at present) and to help establish retrieval priorities for these and assumed leakers, several factors that can facilitate retrieval planning must be addressed. First, the probability of SST failure as a function of tank age will be reviewed, and it will provide a simple statistical summary of historical leak volumes, leak rates, and corrosion factors. The estimated remaining useful life of each tank, based upon factors such as corrosiveness of the waste, maximum waste temperature, and lower knuckle construction, will be evaluated. For those SSTs with a reportable liquid level--supernate measured with a level gauge or interstitial liquids measured by a gamma/neutron probe in the liquid observation wells--an assessment of the significance of historical volume changes and a preliminary estimate of the minimum detectable leak rates should be prepared.

The majority of leaking mechanism data is based on experimental laboratory data and empirical data gathered from tanks under similar conditions as the Hanford tanks. Crack mechanics needs to be explored to determine the potential for tank leakage and to determine methods to mitigate leakage. Hydraulic head will have a significant impact on the selection of tank retrieval technology. Understanding the physical mechanism of tank leakage will ensure retrieval technology selection will minimize overall program cost and schedule.

The end result of this assessment will be a screening of the candidate SSTs for initial hydraulic retrieval based on tank integrity.

\section{E1.3 IMPACTS OF POTENTIAL RETRIEVAL LEAKS}

The impacts associated with retrieval leaks to the vadose zone are being evaluated under the vadose zone program. As the risks are identified the information will be used to help define the requirements for retrieval. 
HNF-2944

Revision 0

\section{E1.4 LEAK DETECTION, MONITORING, AND MITIGATION TECHNOLOGY APPLICATIONS}

The LDMM program's mission is to identify technologies and establish the strategy to detect, monitor and mitigate leakage during the retrieval of the Hanford SSTs. Current LDMM methods do not provide sufficient sensitivity during hydraulic waste retrieval per RCRA and WAC leakage-related regulations.

The following findings were developed from several engineering studies to establish the LDMM baseline for planned SST sluicing campaigns.

- Previous technology surveys did not identify available or deployable, externally applied devices or methods, which can reliably detect waste leakage from an SST during planned SST sluicing operations. Technologies reviewed do not provide an improved detection capability over existing internal technologies.

- Retrieval operations must be capable of responding to detected leakage for leak detection or monitoring tools to be valuable.

- No new (i.e., other than the current baseline approach) internally applied technical devices, or methods, have been identified that can reliably detect waste leakage from an SST within the duration of planned SST sluicing operations.

- The candidate, pre- and post-sluicing monitoring technology, Electrical Resistance Tomography (ERT), could potentially reduce the uncertainty or risk incurred due to leakage by confirming and assessing leakage as small as $3.8 \mathrm{~m}^{3}(1,000 \mathrm{gal})$ or less. Existing (baseline) in-tank leak determination methods have a minimum detection level of $30 \mathrm{~m}^{3}(8,000 \mathrm{gal})$.

The following LDMM measures remain the only currently available suite of tools to support sluicing operations:

- In-tank, liquid/waste level measurement devices and methods for leak detection (i.e., mass balance techniques).

- Neutron/gamma probe "monitoring" devices, and flow modeling data, to provide pre- and post-sluicing leakage plume assessment and concurrence.

- Operational, procedural, and administrative methods, and retrieval equipment design and availability, to mitigate leakage before, and during, sluicing. Engineered systems with demonstrated performance are not available for deployment as barriers beneath tanks for leak mitigation. 
Continued evaluation of candidate LDMM technologies, enhancement of existing technologies, and testing of these tools under actual field conditions will be conducted to support and enhance the retrieval operations of the Hanford SSTs.

\section{E1.5 TANK CONFIGURATION}

The 149 SSTs were constructed in various configurations. One-hundred thirty-three of the 149 are $22.9 \mathrm{~m}(75 \mathrm{ft})$ in diameter with nominal capacities of $1,900 \mathrm{~m}^{3}(500,000 \mathrm{gal})$, $2,800 \mathrm{~m}^{3}(750,000 \mathrm{gal})$, and $3,800 \mathrm{~m}^{3}(1,000,000 \mathrm{gal})$. The remaining $16 \mathrm{SST}$ are $6.1 \mathrm{~m}$ $(20 \mathrm{ft})$ in diameter with capacities of $208 \mathrm{~m}^{3}$ (55,000 gal) (Krieg et al. 1990).

The $22.9 \mathrm{~m}(75 \mathrm{ft})$ diameter tanks are domed top, reinforced-concrete cylindrical structures varying in height from 8.8 to $13.7 \mathrm{~m}(29$ to $45 \mathrm{ft})$. They are lined with steel plate on the sides and bottom. The bottoms of most tanks are dished slightly. The tanks are below

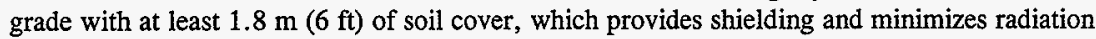
exposure to operating personnel. Inlet and overflow lines are located near the top of the tank liner.

Access to the tanks is provided by risers penetrating the domes of the tanks. Existing risers vary in diameter from 0.1 to $1.1 \mathrm{~m}$ ( 4 to $42 \mathrm{in}$.). Fifty-seven of the tanks also contain pipes used for liquid observation wells. Sixty-four of the $13322.9-\mathrm{m}(75-\mathrm{ft})$ diameter tanks do not have a $1.1-\mathrm{m}$ (42-in.) central riser or hole for access. Thirty-nine of the 133 SSTs have four or five centrally located 1.1-m (42-in.) risers. New risers can be added to an SST but this is very costly.

Active ventilation currently provides cooling for thirteen of the $22.9-\mathrm{m}$ ( $75 \mathrm{ft}$ ) diameter tanks containing high heat wastes.

The sixteen smaller SSTs are $6.1 \mathrm{~m}(20 \mathrm{ft})$ in diameter by $7.3 \mathrm{~m}(24 \mathrm{ft})$ high and have a nominal capacity of $208 \mathrm{~m}^{3}(55,000 \mathrm{gal})$. They have a steel liner on the sides and bottom. The top is flat and the bottom is slightly dished. There are several pipe penetrations in the top of the tanks ranging from 0.04 to $0.3 \mathrm{~m}$ (1.5 to $12 \mathrm{in}$.) in diameter. There is also a $1.1-\mathrm{m}$ (42-in.) diameter manhole in the top located $3.7 \mathrm{~m} \mathrm{(12} \mathrm{ft)} \mathrm{below} \mathrm{grade.}$

Intrusion prevention has been completed on 108 SSTs. Intrusion prevention is the administrative designation reflecting the completion of the physical effort required to minimize the addition of liquids into an inactive storage tank.) Interim stabilization includes the physical blanking of process transfer lines and the heating, ventilating, and air conditioning (HVAC) system.

Tank hardware and supporting systems have been modified over the life of the facility and less than adequate drawing integrity has been maintained. It will be necessary to "as-built" the present SST essential drawings to ensure cost, schedule, and safety of the retrieval project are not jeopardized. 
HNF-2944

Revision 0

\section{E1.6 INFRASTRUCTURE SYSTEMS}

Transfer lines, pits, vaults and other ancillary facilities and equipment that may be required to support the SST retrieval program will likely require significant upgrades and improvements. Many of the existing facilities and systems do not meet current regulatory requirements. Many others are old and could pose a health or safety risk to operate. Physical evaluation of these facilities will be required to access their condition for use in the retrieval program. These upgrades will have a significant cost and schedule impact to the program.

Infrastructure Assessments and Upgrades. Infrastructure needs will be identified to support the retrieval of the SSTs. The following infrastructure elements will be assessed.

- Electrical Power

- Raw, Potable, and Fire Water

- Liquid Effluent and Transfer Systems (transfer lines, valve pits, vaults, etc.)

- Site Development and Roads.

Decisions as to the requirement to build new transfer lines, pit upgrades, transfer line leak detection systems, etc., will be based upon a review of existing plant conditions, design requirements, and discussions with the regulators.

\section{E1.7 RETRIEVAL TECHNOLOGY APPLICATIONS}

Hydraulic sluicing of waste from the SSTs is the current retrieval baseline at Hanford. Known as past-practice sluicing, this technology was used during the 1970's to retrieve waste for reprocessing of radioactive waste sludge. Sluicing uses a medium pressure water nozzle positioned from a riser for waste dislodging and a slurry pump to transfer the waste out of the tank. More than 50 SSTs were retrieved using this method. Although extensively used, the system performance was not specified to the level of performance required by the Hanford Federal Facility Agreement and Consent Order (Tri-Party Agreement) (Ecology et al. 1996) for SST retrieval and performance to this level has not been demonstrated.

Sluicing may also not be appropriate in tanks that have leaked or are assumed to have leaked, therefore alternative technologies are being identified, evaluated and demonstrations planned where prudent. The capabilities of sluicing will be demonstrated, Project W-320, that will sluice the soft sludge waste from $241-\mathrm{C}-106$.

A technology demonstration currently in the development stage as part of HTI is the final retrieval of 241-C-106. Tank 241-C-106 was identified as a tank that had a hard waste heel that was known not to have been retrievable in a previous sluicing campaign. A crawler-based 
waste retrieval system using confined sluicing was selected to be deployed in tank 241-C-106 to demonstrate retrieval of the hard waste after completion of sluicing of bulk wastes. This will demonstrate the ability to retrieve difficult waste forms from the SSTs

A technology demonstration currently in the planning stages is saltcake dissolution. Investigation on saltcake waste dissolution at the Hanford Site and the Savannah River Site suggest that saltcake can be retrieved with a sprinkler retrieval system. In these demonstrations, sprinkler heads placed above the waste allowed water to drip onto the saltcake. One or more salt well pumps are placed in the tank to capture and remove the dissolved saltcake. Given the results of these limited demonstrations, this technology seems to be readily available, inexpensive to deploy in numerous tanks simultaneously, economical to operate and maintain, and water introduction can be adjusted to optimize the retrieval rate. To proceed with a hot demonstration the following steps need to be performed: (1) a feasibility study on saltcake dissolution needs to be completed; (2) determine if bench scale testing of actual saltcake dissolution obtained from a representative tank needs to be performed and if so then do it; (3) if required, a quarter-scale test of a sprinkler system on a representative simulant would be demonstrated; and (4) a demonstration of the technology in a saltcake SST.

Other hydraulic technologies are being considered for retrieval. Over the last two years, a number of systems have been tested and evaluated as part of the Acquire Commercial Technology for Retrieval (ACTR), Tanks Focus Area (TFA), and HTI. Examples include enhanced sluicing systems, borehole miners, and arm-based deployment systems using confined sluicing. A summary of current technologies being evaluated is in Table E-1.

Dry retrieval process technologies could be required for some SSTs. Numerous dry retrieval technologies have been evaluated, or tested over the last 25 years. In the context of minimizing leaks this is an attractive solution but there are many issues associated with dry retrieval of SST wastes. Increased worker hazards and system complexity are some of the issues that simple hydraulic processes do not share. Examples of dry retrieval process technologies are mechanical systems, commercial mining systems, and pneumatic systems.

There is work ongoing throughout the DOE complex looking at retrieval technologies. . Complex-wide waste retrieval activities include the recovery of salt cake and/or sludge-heel wastes in Gunite tanks at the Oak Ridge National Laboratory (ORNL) site and large, steellined tanks at Savannah River Site (SRS) and West Valley Nuclear Services. Fernald will sluice a soil-like waste from two of its silos and dry retrieve powder from a third silo using air lance technology. Retrieval of sludges at ORNL and Idaho National Engineering Environment Laboratory (INEEL) from horizontal steel tanks is also planned. A wide range of waste retrieval characterization and conveyance technologies will be deployed in these retrieval projects, yielding critical performance and cost data. These data will be shared among the sites, facilitated by the Tanks Focus Area (TFA). 
Table E-1. Technology Summary Table.

\begin{tabular}{|c|c|c|c|c|c|}
\hline Technology & Application & Efficiency & Limitations & Deployment & Impact Potential \\
\hline \multicolumn{6}{|c|}{ Sprinkler Systems (Rainbird System) } \\
\hline
\end{tabular}

\section{Sluicing}

High volume, low pressure (100-200 psi) water wash to dislodge and remove the sludge in a slurry format.

\section{Suited for soluble salts} or soft sludge. Not as effective for hard pan or hard heels.
Creates a large volume siurry although carrier fluid may be recycled for waste volume reduction
Largeamount of water depth required for transfer pump increases risk of tank leakage
Sound tanks containing soft sludge, or saltcake. Requires tank infrastructure upgrades and mods.
Potential leakage to

Vadose Zone for suspect or unsound tanks.

\section{Confined Sluicing with Crawler}

High pressure (10 - 50 $\mathrm{ksi})$, low volume water jet with close-coupled low-head pump to dislodge and remove sludge in a slurry.
Suited for soft or hard sludge, incl: hard heal $\&$ hard pan. Capable of very high flow rates.
Creates localized, high energy slurry. Fluid recycle not suitable for this application.
Crawler umbilical lines may be restricted by internal structures.
Tanks containing soft or hard sludge. Requires infrastructure upgrades and mods.
Localized flow minimizes potential leaks. Potential for equipment decon issues

\section{Confined Sluicing with Articulated Arm}

High pressure (10 - 50 ksi), low volume water jet with close-coupled low-head pump to dislodge and remove sludge in a slurry.
Suited for soft or hard sludge, incl: hard heal \& hard pan.
Creates localized, high energy slurry. Fluid recycle not suitable for this application.
Arm reach and geometrical limits on movement. Highly complex mechanism. Reach may be restricted by internal struchures
Tanks containing soft or hard sludge. Requires infrastructure upgrades and mods.

\section{Localized flow} minimizes potential leaks. Potential for equipment decon issues 
Issues analysis for retrieval of SST waste using hydraulic, dry retrieval, and pneumatic methods has identified some additional technology investigations that need to be performed. These technology investigations are currently underway or in the planning stages. Before additional technology investigations can be finalized, further analysis will be completed to determine additional issues to be resolved before optimization of the SST retrieval strategy.

As part of the SST retrieval strategy optimization a determination of which retrieval technology to use on a tank-by-tank basis will be made. This will not be complete until the decision analysis discussed in Section E2.0 has been conducted. 
HNF-2944

Revision 0

\section{E2.0 DEPLOYMENT DECISION TOOLS}

Decision support tools will be used to support development of risk-based, economical SST retrieval strategy and retrieval technology selection. Existing and emerging data will be used to measure the performance of SST retrieval strategies relative to program objectives.

Decision tools will be employed that optimize the program's retrieval performance, minimize risk to the public and the environment, and minimize programmatic costs. Performance metrics to be evaluated with the decision tools include the following:

- Assure that potentially leaked contaminants during retrieval do not pose a public health or environmental risk.

- Prioritize SST retrieval sequencing based on reduction of long term risks.

- Minimize SST retrieval costs.

- Minimize the potential for leakage during SST retrieval.

- Provide SST waste to feed DSTs to support the privatized immobilization facility requirements.

- Maximize SST retrieval to support resolution of safety issues.

- Optimize SST retrieval sequencing to support implementation of tank farm closure milestones.

- Determine retrieval technology selection.

- Prioritize SST retrieval sequencing based on feasibility of retrieval considering intank hardware and infrastructure status/logistics.

Two analytical tools will be used in evaluating these metrics. The first is a Retrieval Evaluation Model (REM) under development by Jacobs Engineering for the purpose of optimizing studies of retrieval scenarios based on selected static retrieval parameters and evaluation metrics. The second analytic tool is the Hanford Tank Waste Operation Simulator (HTWOS) Model.

The REM will evaluate the relationship between existing and emerging data and performance evaluation metrics. Retrieval technologies and scenarios will be optimized using REM to screen input into HTWOS. These optimization studies will include parameters influencing and constraining retrieval and evaluation of metrics, such as retrieval rate, risks, cost, retrieval leakage, and infrastructure costs. The output of these optimization studies will then be provided as input to HTWOS. 
HNF-2944

Revision 0

HTWOS will model the dynamic operation of the tank farm systems based on the proposed retrieval technology, retrieval constraints and the preliminary optimization by REM. HTWOS will simulate operational waste volume projection (OWVP) activities, low-level waste (LLW) feed staging activities, HLW feed staging activities, and SST retrieval activities providing a common and integrated performance baseline for all activities. Tank farm operational constraints, as well as physical equipment capabilities are also modeled. The final optimization simulations will provide the basis for technology evaluation and decision risking. The integration of HTWOS and REM with input data is shown in Figure E-1. 


\section{DEPLOYMENT DECISION TOOLS}

$\stackrel{T}{1}$

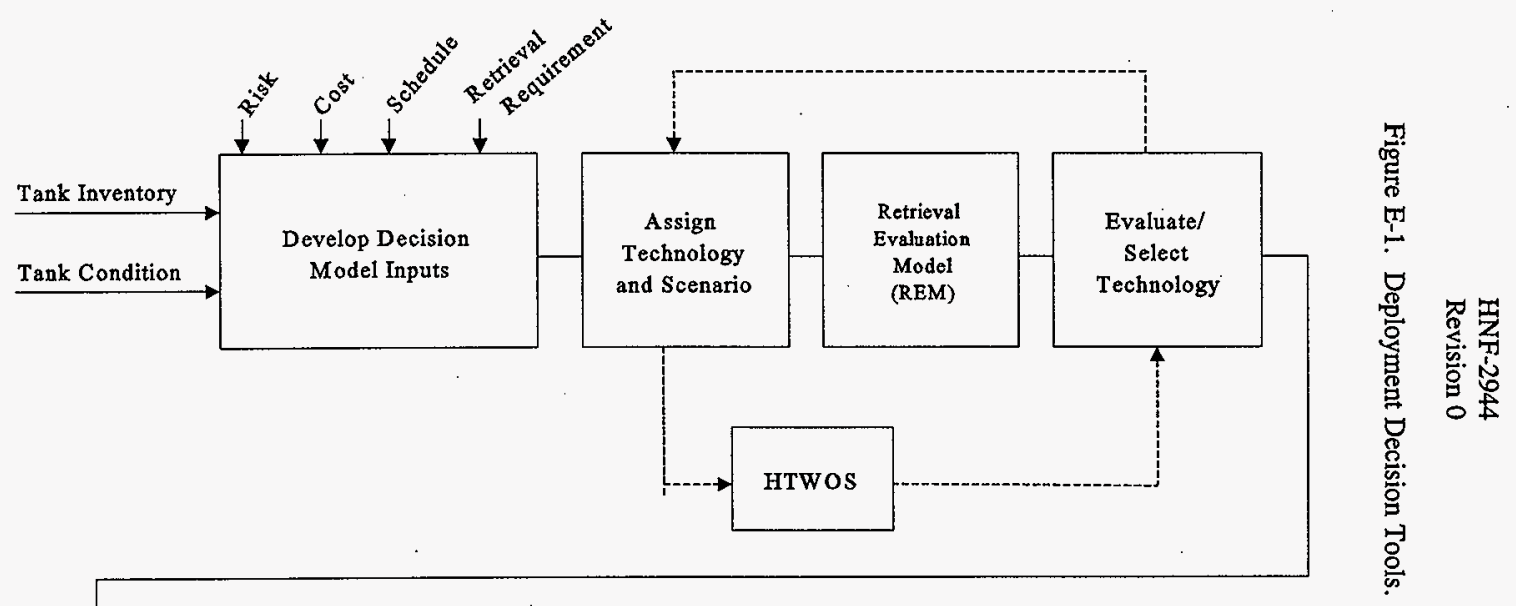

Hanford Tank Waste

Operations Simulator (HTWOS)

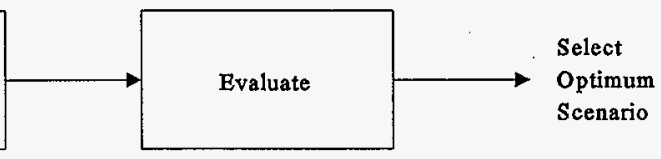


Table E-2. Complex-Wide Retrieval and Closure Activities. (5 Sheets)

\begin{tabular}{|c|c|c|c|c|c|}
\hline Project & Key objectives & Technical Issuess & $\begin{array}{l}\text { Techinologies } \\
\text { Inplemented }\end{array}$ & $\begin{array}{l}\text { Deployment } \\
\text { Schedule. }\end{array}$ & Applicability \\
\hline $\begin{array}{l}\text { Gunite And } \\
\text { Associated Tanks } \\
\text { (GAAT) treatability } \\
\text { study W-3 and W-4 } \\
\text { Tanks and North } \\
\text { Tank Farm } \\
\text { ORNL }\end{array}$ & $\begin{array}{l}\text { Waste } \\
\text { treatability issue } \\
\text { resolution } \\
\text { Retrieval and } \\
\text { closure criteria } \\
\text { Demonstrate the } \\
\text { ability to retrieve } \\
\text { waste in the } \\
\text { GAAT }\end{array}$ & $\begin{array}{l}\text { Retrieval of } \\
\text { sludge waste from } \\
\text { two twenty-foot } \\
\text { điameter Tanks. } \\
\text { Cost effectiveness } \\
\text { of retrieval versus } \\
\text { risk } \\
\text { Retrieval system } \\
\text { effectiveness }\end{array}$ & $\begin{array}{l}\text { Modiffed } \\
\text { LDUA, robotic } \\
\text { arm } \\
\text { Houdini } \\
\text { remote-control } \\
\text { vehicle } \\
\text { Confined } \\
\text { sluicing end } \\
\text { effector } \\
\text { Jet pump waste } \\
\text { removal/water } \\
\text { scavenging }\end{array}$ & $\begin{array}{l}\text { Spring } \\
1997-\text { Fall } \\
1997\end{array}$ & $\begin{array}{l}\text { Experience with } \\
\text { retrieval systems } \\
\text { deployment and } \\
\text { process } \\
\text { performance }\end{array}$ \\
\hline $\begin{array}{l}\text { Remediation of the } \\
\text { GAAT Operable } \\
\text { Unit. ORNL }\end{array}$ & $\begin{array}{l}\text { Retrieve the } \\
\text { waste from the } \\
\text { GAAT and } \\
\text { prepare them for } \\
\text { closure. }\end{array}$ & $\begin{array}{l}\text { Retrieval of waste } \\
\text { from six larger } \\
\text { (50 ft diameter) } \\
\text { tanks. } \\
\text { Retrieval of waste } \\
\text { from tanks } \\
\text { containing several } \\
\text { feet of sludge and } \\
\text { some hard } \\
\text { đeposits. } \\
\text { Tank } \\
\text { decontamination } \\
\text { Conditioning of } \\
\text { waste for slurry } \\
\text { transfer to Melton } \\
\text { Valley Storage } \\
\text { Tanks }\end{array}$ & $\begin{array}{l}\text { MLDUA, } \\
\text { robotic arm } \\
\text { Houdini } \\
\text { remote-control } \\
\text { vehicle } \\
\text { Confined } \\
\text { sluicing end } \\
\text { effector } \\
\\
\text { Jet pump waste } \\
\text { removal/water } \\
\text { scavenging } \\
\text { Waste } \\
\text { Conditioning } \\
\text { System for } \\
\text { transfer }\end{array}$ & $\begin{array}{l}\text { Fall } 1997 \text { - } \\
\text { Fall } 2001\end{array}$ & $\begin{array}{l}\text { Experience with } \\
\text { retrieval system } \\
\text { deployment and } \\
\text { process } \\
\text { performance, as } \\
\text { well as larger } \\
\text { scale field } \\
\text { operations }\end{array}$ \\
\hline
\end{tabular}


Table E-2. Complex-Wide Retrieval and Closure Activities. (5 Sheets)

\begin{tabular}{|c|c|c|c|c|c|}
\hline 1.4 .9 poject & Key objectives & Technical Issues & $\begin{array}{l}\text { Technologies } \\
\text { limplemented }\end{array}$ & Deployment & Applicability \\
\hline $\begin{array}{l}\text { Old Hydro-Fracture } \\
\text { (OHF) Tanks } \\
\text { ORNL }\end{array}$ & $\begin{array}{l}\text { Retrieve Waste, } \\
\text { Clean out tanks } \\
\text { for closure }\end{array}$ & $\begin{array}{l}\text { Retrieval of sludge } \\
\text { waste from five } \\
\text { horizontal } \\
\text { underground steel } \\
\text { tanks } \\
\\
\text { Effectiveness of } \\
\text { Extendable Nozzle } \\
\text { Bore Hole Miner } \\
\text { (500-2000 psi) } \\
\text { sluicing system }\end{array}$ & $\begin{array}{l}\text { Extendable } \\
\text { Nozzle Bore } \\
\text { Hole Miner } \\
\text { sluicing system }\end{array}$ & $\begin{array}{l}\text { Spring } 1998 \\
\text {-Fall } 1998\end{array}$ & $\begin{array}{l}\text { Field experience } \\
\text { with retrieval } \\
\text { system } \\
\text { deployment. } \\
\text { Retrieval } \\
\text { performance } \\
\text { objectives will be } \\
\text { determined } \\
\text { Permitting issues } \\
\text { for operations }\end{array}$ \\
\hline $\begin{array}{l}\text { Bethel Valley } \\
\text { Evaporator Storage } \\
\text { Tanks (BVEST) } \\
\text { ORNL W-21, 22, } \\
\text { and } 23\end{array}$ & $\begin{array}{l}\text { Retrieve sludge } \\
\text { waste. } \\
\text { Clean out tanks } \\
\text { for reuse, } \\
\text { removing TRU } \\
\text { contamination }\end{array}$ & $\begin{array}{l}\text { Effectiveness of } \\
\text { pneumatic } \\
\text { powered water } \\
\text { pulse jets (AEA } \\
\text { Technology) } \\
\text { when deployed } \\
\text { through existing } \\
\text { tank nozzle sets. } \\
\text { in three } 60 \text { foot } \\
\text { long by } 12 \text { foot } \\
\text { diameter tanks }\end{array}$ & $\begin{array}{l}\text { AEA fluidic } \\
\text { pulse jet }\end{array}$ & $\begin{array}{l}\text { Fall 1997- } \\
\text { Spring } 1998\end{array}$ & $\begin{array}{l}\text { Retrieval } \\
\text { performance will } \\
\text { be determined }\end{array}$ \\
\hline $\begin{array}{l}\text { Bethel Valley } \\
\text { Evaporator Storage } \\
\text { Tanks (BVEST) } \\
\text { ORNL C-1, C-2 }\end{array}$ & $\begin{array}{l}\text { Retrieve sludge } \\
\text { waste. } \\
\text { Clean out tanks } \\
\text { for reuse, } \\
\text { removing TRU } \\
\text { contamination }\end{array}$ & $\begin{array}{l}\text { Effectiveness of } \\
\text { pneumatic } \\
\text { powered water } \\
\text { pulse jets (AEA } \\
\text { Technology) } \\
\text { when deployed } \\
\text { through risers } \\
\text { with steerable, } \\
\text { optimal jets in } \\
\text { two thirty foot, } \\
\text { twelve foot } \\
\text { diameter tanks. }\end{array}$ & $\begin{array}{l}\text { AEA fluidic } \\
\text { pulse jet }\end{array}$ & $\begin{array}{l}\text { Fall 1998- } \\
\text { Fall } 1999\end{array}$ & $\begin{array}{l}\text { Retrieval } \\
\text { performance will } \\
\text { be determined }\end{array}$ \\
\hline $\begin{array}{l}\text { Meiton Valley } \\
\text { Storage Tanks } \\
\text { (MVST) } \\
\text { ORNL }\end{array}$ & $\begin{array}{l}\text { Retrieve waste } \\
\text { for } \\
\text { immobilization } \\
\text { and tank reuse }\end{array}$ & $\begin{array}{l}\text { Privatization of } \\
\text { retrieval } \\
\text { processes }\end{array}$ & $\begin{array}{l}\text { Will be selected } \\
\text { by .Foster- } \\
\text { Wheeler, the } \\
\text { newly selected } \\
\text { remediation } \\
\text { contractor. }\end{array}$ & $\begin{array}{l}\text { RFP- } \\
\text { Winter } 1997 \\
\text { Retrieval } \\
\text { Operations- } \\
\text { Fall } 2001\end{array}$ & $\begin{array}{l}\text { Specification for } \\
\text { private vendor } \\
\text { retrieval of tank } \\
\text { waste }\end{array}$ \\
\hline
\end{tabular}


HNF-2944

Revision 0

Table E-2. Complex-Wide Retrieval and Closure Activities. (5 Sheets)

\begin{tabular}{|c|c|c|c|c|c|}
\hline Project & Key objectives: & Technicalissures. & $\begin{array}{l}\text { Techinologies: } \\
\text { implemented }\end{array}$ & $\begin{array}{l}\text { Deployment } \\
\text { Schedule }\end{array}$ & Applicability \\
\hline $\begin{array}{l}\text { V-Tank Closure } \\
\text { INEL }\end{array}$ & $\begin{array}{l}\text { Close CERCLA } \\
\text { Tanks } \\
\text { Stabilize residual } \\
\text { waste heels }\end{array}$ & 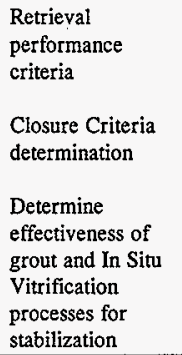 & $\begin{array}{l}\text { This will be } \\
\text { determined by } \\
\text { the approved } \\
\text { remediation } \\
\text { plan }\end{array}$ & $\begin{array}{l}\text { ROD - FY } \\
1998 \\
\text { Remediation } \\
\text { FY 1999, } \\
\text { FY 2000 }\end{array}$ & $\begin{array}{l}\text { Field experience } \\
\text { with retrieval } \\
\text { system } \\
\text { deployment. } \\
\text { Retrieval } \\
\text { performance } \\
\text { objectives will be } \\
\text { determined } \\
\text { Permitting issues } \\
\text { for operations }\end{array}$ \\
\hline $\begin{array}{l}\text { F - Tank Farm } \\
\text { Closure Tanks } \\
\text { 17-20F } \\
\text { Savannah River Site }\end{array}$ & $\begin{array}{l}\text { Declare tanks } \\
\text { out of service } \\
\text { and ready for } \\
\text { closure followed } \\
\text { by individual } \\
\text { tank closure, } \\
\text { then tank four- } \\
\text { pack closure } \\
\text { including closure } \\
\text { of tank } \\
\text { monitoring } \\
\text { control room } \\
\text { Retrieval of Heel } \\
\text { Wastes for tank } \\
\text { closure as } \\
\text { required }\end{array}$ & $\begin{array}{l}\begin{array}{l}\text { Source term of } \\
\text { heel waste }\end{array} \\
\text { Performance } \\
\text { objectives for } \\
\text { tank residual } \\
\text { waste } \\
\text { Stabilization of } \\
\text { tank } \\
\text { NRC "Incidental } \\
\text { Waste" } \\
\text { determination } \\
\text { Eighty-foot } \\
\text { diameter, } 1.2 \\
\text { million gallon } \\
\text { tanks } \\
\text { 1F Evaporator pot } \\
\text { Waste Retrieval } \\
\text { and Closure }\end{array}$ & $\begin{array}{l}\text { Closure } \\
\text { performance } \\
\text { evaluation } \\
\text { Flygt Mixers, } \\
\text { 200psi, 125 } \\
\text { gpm sluicers, } \\
\text { centrifugal } \\
\text { pumps, double- } \\
\text { diaphragm } \\
\text { pumps, Pit-Bull } \\
\text { pumps, water- } \\
\text { mouse waste } \\
\text { distributer, } \\
\text { three point } \\
\text { grout pour } \\
\text { retrieval sump } \\
\text { creation, } \\
\text { Reducing grout, } \\
\text { controlled low- } \\
\text { strength } \\
\text { material } \\
\text { (CLSM) fill, } \\
\text { Reducing } \\
\text { CLSM fill. } \\
\text { Disposable } \\
\text { vehicle tool . } \\
\text { deployment } \\
\text { platform. }\end{array}$ & 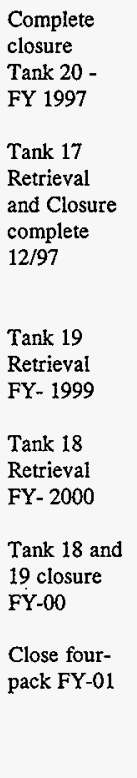 & $\begin{array}{l}\text { Development of } \\
\text { closure criteria } \\
\text { Closure methods } \\
\text { Closure } \\
\text { performance } \\
\text { assessment } \\
\text { NRC } \\
\text { classification } \\
\text { of residual waste } \\
\text { Tank Stabilization } \\
\text { methods }\end{array}$ \\
\hline
\end{tabular}


Table E-2. Complex-Wide Retrieval and Closure Activities. (5 Sheets)

\begin{tabular}{|c|c|c|c|c|c|}
\hline 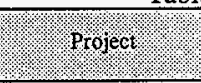 & Key Objectives & Technical tssurs & $\begin{array}{l}\text { Technologies } \\
\text { Implemented }\end{array}$ & Deployment & Applicability \\
\hline $\begin{array}{l}\text { Tank 25/41 Salt } \\
\text { Retrieval } \\
\text { Savannah River Site }\end{array}$ & $\begin{array}{l}\text { Test alternative } \\
\text { retrieval } \\
\text { technologies to } \\
\text { replace } \\
\text { expensive large } \\
\text { mixer pumps for } \\
\text { salt retrieval }\end{array}$ & $\begin{array}{l}\text { Slower dissolution } \\
\text { of salt cake } \\
\text { Reduce need for } \\
\text { expensive mixer } \\
\text { pump } \\
\text { Retrieve insoluble } \\
\text { waste }\end{array}$ & $\begin{array}{l}\text { AEA Fluidic } \\
\text { Diode Transfer } \\
\text { Pump } \\
\text { (Proposed) } \\
\text { Water-Monitor } \\
\text { sluicer for } \\
\text { retrieving salt } \\
\text { from tank } \\
\text { upper structure } \\
\text { and bulk salt } \\
\text { dissolution } \\
\text { (Proposed) } \\
\end{array}$ & FY-1999 & $\begin{array}{l}\text { Technique for salt } \\
\text { cake removal by } \\
\text { sluicing for HTI } \\
\text { follow-on. } \\
\text { Experience with } \\
\text { retrieval system } \\
\text { deployment and } \\
\text { process } \\
\text { performance }\end{array}$ \\
\hline $\begin{array}{l}\text { Tanks 8D1 and 8D2 } \\
\text { West Valley } \\
\text { Nuclear Services }\end{array}$ & $\begin{array}{l}\text { Retrieve tank } \\
\text { waste, } \\
\text { immobilize } \\
\text { waste, and close } \\
\text { tanks }\end{array}$ & $\begin{array}{l}\begin{array}{l}\text { Establish tank } \\
\text { closure criteria }\end{array} \\
\begin{array}{l}\text { Determine } \\
\text { residual waste } \\
\text { retrieval methods }\end{array} \\
\text { Determine } \\
\text { retrieval } \\
\text { performance } \\
\text { objectives }\end{array}$ & $\begin{array}{l}\text { Mixer pump } \\
\text { Mini sluicer } \\
\text { Possible } \\
\text { additional } \\
\text { technology } \\
\text { including the } \\
\text { Tarzan mobile } \\
\text { deployment } \\
\text { platform }\end{array}$ & On Going & $\begin{array}{l}\text { Field experience } \\
\text { with retrieval } \\
\text { system } \\
\text { deployment. } \\
\text { Retrieval } \\
\text { performance } \\
\text { objectives will be } \\
\text { determined } \\
\text { Permitting issues } \\
\text { for operations }\end{array}$ \\
\hline $\begin{array}{l}\text { Tank C-106, } \\
\text { Project W-320 } \\
\text { Hanford Site }\end{array}$ & $\begin{array}{l}\text { Retrieve heat- } \\
\text { generating soft } \\
\text { sludge from tank } \\
\text { using Past- } \\
\text { Practice Sluicing }\end{array}$ & $\begin{array}{l}\text { Heat generation in } \\
\text { sludge that } \\
\text { requires cooling } \\
\text { water addition. } \\
\text { Slurry transfer } \\
\text { parameters } \\
\text { Flammable gas } \\
\text { safety in tank }\end{array}$ & $\begin{array}{l}\text { Past-practice } \\
\text { sluicing (low } \\
\text { pressure - } 200 \\
\text { psi, long range- } \\
75 \mathrm{ft} \text { ) }\end{array}$ & Fall, 1998 & $\begin{array}{l}\text { First stage of } \\
\text { C-106 waste } \\
\text { retrieval. HTI } \\
\text { will remove tank } \\
241-C-106 \text { hard- } \\
\text { heel waste not } \\
\text { retrieved by } \\
\text { sluicing. } \\
\text { Shared. } \\
\text { infrastructure and } \\
\text { site operations } \\
\text { experience }\end{array}$ \\
\hline
\end{tabular}


HNF-2944

Revision 0

Table E-2. Complex-Wide Retrieval and Closure Activities. (5 Sheets)

\begin{tabular}{|c|c|c|c|c|c|}
\hline project & Rey objectives & Technical Issues & $\begin{array}{l}\text { Techinologies } \\
\text { Implemented }\end{array}$ & Deployment & Applicability \\
\hline $\begin{array}{l}\text { Hanford Tanks } \\
\text { Initiative (HTI) } \\
\text { (Includes ACTR } \\
\text { work) } \\
\text { Hanford Site }\end{array}$ & $\begin{array}{l}\text { Develop tool box } \\
\text { of retrieval and } \\
\text { deployment } \\
\text { systems and } \\
\text { processes } \\
\text { Retrieve hard } \\
\text { heel waste from } \\
\text { Tank C-106 } \\
\text { Characterize } \\
\text { residual waste in } \\
\text { and around AX- } \\
104 \text { to determine } \\
\text { retrieval } \\
\text { performance } \\
\text { objectives }\end{array}$ & $\begin{array}{l}\text { Effectiveness and } \\
\text { availability of } \\
\text { commercial } \\
\text { technologies } \\
\text { Provide retrieval } \\
\text { and deployment } \\
\text { concepts } \\
\text { Identify industrial } \\
\text { sources of } \\
\text { retrieval and } \\
\text { deployment } \\
\text { equipment }\end{array}$ & $\begin{array}{l}\text { MPW water jet } \\
\text { technology, } \\
\text { ARD vehicle- } \\
\text { based tank- } \\
\text { cleaning service } \\
\text { ESG vehicle } \\
\text { based tank } \\
\text { cleaning service } \\
\text { Gray Pilgrim, } \\
\text { novel in-tank } \\
\text { manipulator; } \\
\text { Bristol water } \\
\text { monitor } \\
\text { Delphinus/ } \\
\text { EagleTec arm } \\
\text { based retrieval } \\
\text { system }\end{array}$ & $\begin{array}{l}\text { Retrieve C- } \\
106 \text { Heel } \\
\text { FY } 2000 \\
\text { Closure } \\
\text { performance } \\
\text { data for } \\
\text { AX-104 } \\
\text { FY-2000 }\end{array}$ & $\begin{array}{l}\text { Demonstrate } \\
\text { alternate retrieval } \\
\text { technologies to } \\
\text { sluicing }\end{array}$ \\
\hline $\begin{array}{l}\text { Silo Remediation } \\
\text { Fernald }\end{array}$ & $\begin{array}{l}\text { Retrieve waste } \\
\text { from silos and } \\
\text { transfer to } \\
\text { interim storage } \\
\text { facility (Silos } 1 \\
\& \text { 2); } \\
\text { Immobilize } \\
\text { (probably grout } \\
\text { for Silo 3) }\end{array}$ & $\begin{array}{l}\text { Retrieval system } \\
\text { Performance. } \\
\text { Waste Transfer } \\
\text { Issues } \\
\text { Silo closure }\end{array}$ & $\begin{array}{l}\text { Two } \\
\text { commercial } \\
\text { contracts in } \\
\text { process to } \\
\text { select retrieval } \\
\text { process for } \\
\text { Silos } 1 \& 2 \text { and } \\
\text { for Silo } 3\end{array}$ & $\begin{array}{l}\text { Start } \\
\text { Retrieval } \\
\text { FY 2000 } \\
\text { [TBD] }\end{array}$ & $\begin{array}{l}\text { Retrieval } \\
\text { Performance data. } \\
\text { Site Operations } \\
\text { Experience } \\
\text { Closure Criteria }\end{array}$ \\
\hline
\end{tabular}


Table E-3. Listing of Technologies with Potential to Support the Single-Shell Tank Program. (3 Sheets)

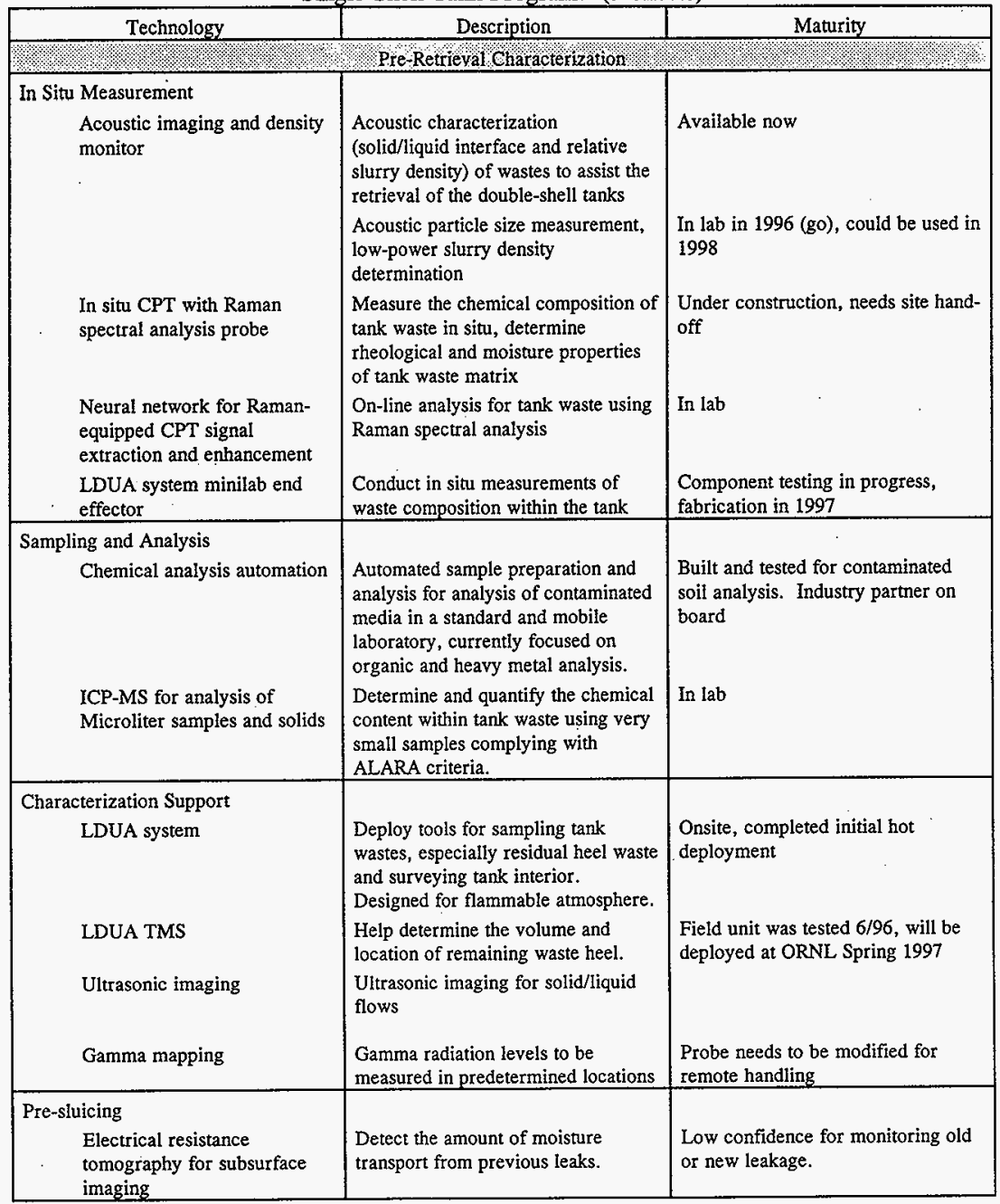


HNF-2944

Revision 0

Table E-3. Listing of Technologies with Potential to Support the Single-Shell Tank Program. (3 Sheets)

\begin{tabular}{|c|c|c|}
\hline Technology & Description & Maturity \\
\hline \multicolumn{3}{|c|}{ Retrieyal } \\
\hline \multicolumn{3}{|l|}{ Retrieval Support } \\
\hline LDUA system & $\begin{array}{l}\text { Recover and repair broken devices, } \\
\text { relocate small in-tank equipment, } \\
\text { and perform small-scale retrieval } \\
\text { tasks. }\end{array}$ & $\begin{array}{l}\text { Onsite, completed first hot } \\
\text { deployment. }\end{array}$ \\
\hline Houdini & $\begin{array}{l}\text { Recover and repair broken devices, } \\
\text { relocate small in-tank equipment, } \\
\text { and perform retrieval tasks. }\end{array}$ & $\begin{array}{l}\text { Deployed in ORNL tanks in } \\
\text { FY } 1997\end{array}$ \\
\hline \multicolumn{3}{|l|}{ Retrieval Enhancements } \\
\hline Enhanced unconfined sluicing & $\begin{array}{l}\text { Improvements to past-practice slicing } \\
\text { (200 psi, } 100 \mathrm{gal} / \mathrm{min}) \text {. }\end{array}$ & FY 1998 \\
\hline Pulse-Air (Reg. TM) & $\begin{array}{l}\text { Mixing by large bubbles. Suitable } \\
\text { for process or conditioning; tank } \\
\text { mixing. Could be used for in-tank } \\
\text { grout mixing. }\end{array}$ & $\begin{array}{l}\text { Commercially available, } \\
\text { proprietary. Has not been deployed } \\
\text { in large tanks }\end{array}$ \\
\hline Borehole mining & $\begin{array}{l}\text { Unconfined sluicer ( } 500 \text { to } 3,000 \mathrm{psi} \\
\text { at } 75 \text { to } 150 \mathrm{gal} / \mathrm{min}) \text { that can be } \\
\text { deployed with integral pump through } \\
\text { a } 30 \mathrm{~cm}(12-\mathrm{in} \text {.) access port. }\end{array}$ & Commercially available \\
\hline $\begin{array}{l}\text { Confined sluicing scarifier } \\
\text { with jet pump }\end{array}$ & $\begin{array}{l}10,000 \text { psi waterjet scarifier used } \\
\text { with the jet pump conveyance (low } \\
\text { water addition); weighs } 25 \text { lbs. }\end{array}$ & $\begin{array}{l}\text { Ready for testing. To be deployed } \\
\text { for waste retrieval at ORNL 11/96. }\end{array}$ \\
\hline Light-weight scarifier & $\begin{array}{l}50,000 \text { psi water jet scarifier used } \\
\text { with air conveyance (low water } \\
\text { addition, for stubborn waste forms); } \\
\text { weighs } 50 \text { lbs. }\end{array}$ & $\begin{array}{l}\text { Prototype has been built; ready for } \\
\text { testing. }\end{array}$ \\
\hline \multicolumn{3}{|l|}{ ACTR/HTI Retrieval evaluations } \\
\hline Retrieval database & $\begin{array}{l}\text { Determine commercially available } \\
\text { best approaches to retrieving waste. } \\
\text { Develop applicability of database } \\
\text { based on site conditions and desired } \\
\text { results. }\end{array}$ & $\begin{array}{l}\text { Available on internet at } \\
\text { WWw.tanks.org }\end{array}$ \\
\hline $\begin{array}{l}\text { Vehicle-based tank cleaning } \\
\text { services }\end{array}$ & $\begin{array}{l}\text { Evaluated and tested vehicle based } \\
\text { systems with commercial service } \\
\text { providers }\end{array}$ & Ready for deployment \\
\hline $\begin{array}{l}\text { Waterjet tank cleaning } \\
\text { services }\end{array}$ & $\begin{array}{l}\text { Evaluated system for cleaning tanks } \\
\text { using rotating high pressure water } \\
\text { jets. }\end{array}$ & Ready for business \\
\hline $\begin{array}{l}\text { manipulator based retrieval } \\
\text { systems }\end{array}$ & $\begin{array}{l}\text { Evaluated commercially available } \\
\text { manipulator deployment devices that } \\
\text { can be used for retrieval }\end{array}$ & Systems available \\
\hline
\end{tabular}


Table E-3. Listing of Technologies with Potential to Support the Single-Shell Tank Program. (3 Sheets)

\begin{tabular}{|c|c|c|}
\hline Technology & Description & Maturity \\
\hline \multirow{2}{*}{$\begin{array}{l}\text { Process Monitoring During Sluicing } \\
\text { ERT with CPT emplacement } \\
\text { leak detection and monitoring }\end{array}$} & & \\
\hline & $\begin{array}{l}\text { Determine extent of tank leakage } \\
\text { during retrieval operations. Not } \\
\text { necessarily an early-warning leak } \\
\text { detection system. }\end{array}$ & $\begin{array}{l}\text { Tank farm deployment will be } \\
\text { addressed in FY } 1997 .\end{array}$ \\
\hline $\begin{array}{l}\text { In situ viscosity and density } \\
\text { monitoring using quartz } \\
\text { resonators }\end{array}$ & $\begin{array}{l}\text { Measures density and viscosity of } \\
\text { mixed-waste tank slurries during } \\
\text { pipeline transport. }\end{array}$ & Successful lab test \\
\hline \multicolumn{3}{|c|}{ Post Retrieval } \\
\hline Houdini & $\begin{array}{l}\text { Provide vehicle to determine residual } \\
\text { tank waste volume and } \\
\text { characteristics, and to } \\
\text { decontaminate and decommission } \\
\text { tanks. }\end{array}$ & $\begin{array}{l}\text { Platform will be deployed in ORNL } \\
\text { tanks in early FY } 1997 .\end{array}$ \\
\hline LDUA & $\begin{array}{l}\text { Provide a means to determine } \\
\text { residual tank waste volume. }\end{array}$ & $\begin{array}{l}\text { Onsite, deployed in a hot tank in } \\
\text { 9/96. }\end{array}$ \\
\hline \multicolumn{3}{|c|}{ Stabilizationiclosure } \\
\hline $\begin{array}{l}\text { In situ grouting and grout } \\
\text { injection }\end{array}$ & Stabilize tank residuals. & $\begin{array}{l}\text { Under consideration at SRS. Will } \\
\text { be tested at INEL in FY 1996/ } \\
\text { 1997. }\end{array}$ \\
\hline Closure criteria & $\begin{array}{l}\text { Evaluate release and transport of } \\
\text { contaminant residual waste and the } \\
\text { effects of their transport through the } \\
\text { vadose zone and aquifer. }\end{array}$ & $\begin{array}{l}\text { Ongoing in support of closure of } \\
\text { Hanford Site tanks. }\end{array}$ \\
\hline
\end{tabular}

$\begin{array}{ll}\text { ACTR } & =\text { Acquire Commercial Technology for Retrieval } \\ \text { ALARA } & =\text { As low as reasonably achievable } \\ \text { CPT } & =\text { Cone penetrometer } \\ \text { ERT } & =\text { Electrical resistance tomography } \\ \text { ICP-MS } & =\text { Inductively coupled plasma-mass spectrometry } \\ \text { INEL } & =\text { Idaho National Engineering Laboratory } \\ \text { LDUA } & =\text { Light-duty utility arm } \\ \text { METC } & =\text { Morgantown Energy Technology Center } \\ \text { ORNL } & =\text { Oak Ridge National Laboratory } \\ \text { SRS } & =\text { Savannah River Site } \\ \text { TMS } & =\text { Topographical mapping system. }\end{array}$


HNF-2944

Revision 0

\section{E3.0 REFERENCES}

Ecology, EPA, and DOE, 1996, Hanford Federal Facility Agreement and Consent Order, as amended, Washington State Department of Ecology, U.S. Environmental Protection Agency, and the U.S. Department of Energy, Olympia, Washington.

Han, F. C., 1996, Delphi Expert Panel Evaluation Hanford High-Level Waste Tank Failure Modes and Release Quantities, WHC-FD-TWR-RPT-003, Rev. 0, Westinghouse Hanford Company, Richland, Washington.

Krieg, S. A., W. W. Jenkins, K. J. Leist, K. G. Squires, and J. F. Thompson, 1990, SingleShell Tank Waste Retrieval Study, WHC-EP-0352, Rev. 0, Westinghouse Hanford Company, Richland, Washington. 
HNF-2944

Revision 0

This page intentionally left blank. 